\title{
Transgressive Gestures: Women and Violin Performance in Eighteenth-Century Europe
}

Hester Bell Jordan

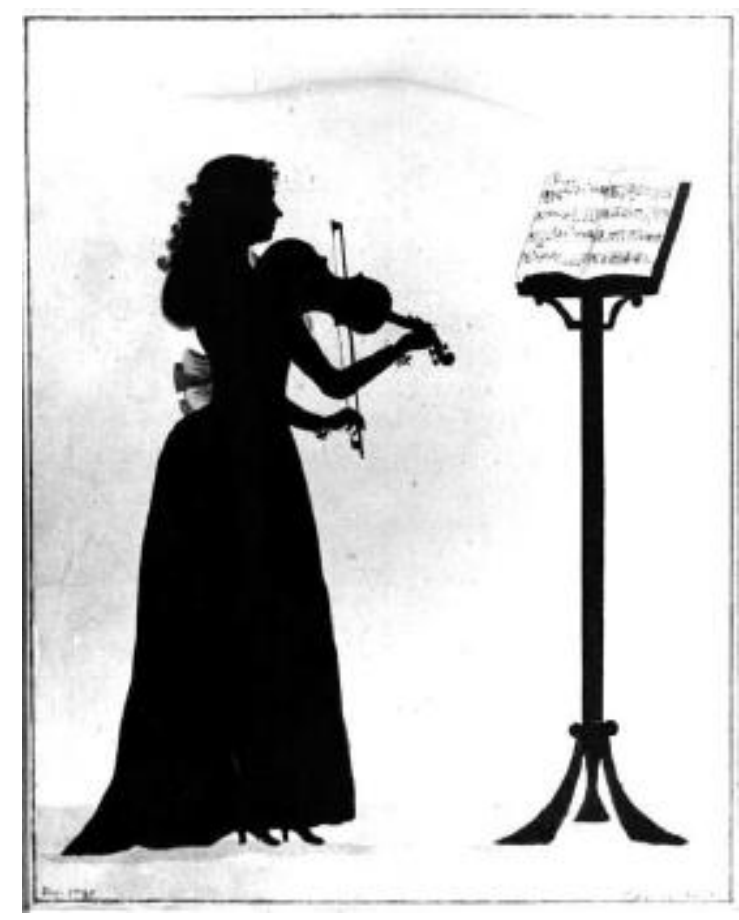

A thesis

submitted to Massey University and Victoria University of Wellington in partial fulfilment of the requirements for the degree of

Master of Music in Musicology

New Zealand School of Music 
(C) Copyright by

Hester Bell Jordan

All rights reserved

April 2016 


\begin{abstract}
Studies concerning eighteenth- and early nineteenth-century women musicians abound within recent musicological scholarship, but the focus on singers and keyboard players whose musical activities are understood to have "affirmed" their femininity - has had the effect of obscuring players of less typical instruments. Violin-playing, frequently cast as a man's activity and imbued with indecent associations, was a case in point. Yet despite the connotations of the instrument, a small but significant group of women did play the violin: it is these violinists that this thesis takes as its central focus. Looking first at the complex reasons behind objections to women's violin performance, a number of factors that restricted women's access to the violin - including the influence of the male gaze and limits placed on women's physical movement - are revealed. Particular conditions nevertheless enabled certain women to play the violin, namely the personal, educational, and economic support available from diverse sources such as family members, patrons, and institutions like convents and the Venetian ospedali.

In addition to placing women violinists in their historical context, this thesis centres on an analysis of a violin concerto by one of the most well-known female violinists of the era, the Italian virtuoso Regina Strinasacchi. The analysis of Strinasacchi's Violin Concerto in B flat major is strongly performance based and focuses on the issue of gender and physical movement (performance gesture), topics which were of much interest to eighteenth-century commentators who witnessed women violinists performing. As such the analysis engages with concepts from "embodied" musicology. In exploring Strinasacchi's concerto we see that female violinists could experiment with a variety of gendered roles through violin performance, embodying both masculinity and femininity through their transgressive gestures. By taking a closer look at women's violin performance and experiences, this thesis aims to show that these violinists were not as peripheral to the workings of the wider musical community as is sometimes implied. Furthermore, it aims to put women violinists more firmly at the centre of their own stories, challenging the tendency to treat female violinists as novel anomalies.
\end{abstract}




\section{Acknowledgements}

There are many people to thank for bringing this thesis to fruition. Firstly my supervisor, Dr Inge van Rij, for her constant support, encouragement, and thoughtful feedback throughout the researching and writing process.

Also my secondary supervisor, Prof. Peter Walls for generously allowing me to borrow a Classical-era violin on which to explore eighteenth-century modes of playing, for giving me lessons on eighteenth-century technique, and for challenging me to always look at my writing with a critical eye.

I would like to thank my examiners, Erin Helyard and Samantha Owens, for their thoughtful and in depth feedback on this thesis which has helped to make it a richer piece of research and a strong piece of writing.

To my parents, for helping me to get where I am today through love and support of many kinds. Mum - thank you for always wanting to hear about my latest discoveries, and for proofreading. And Dad - thank you for your sage advice, reassurance, and encouraging feedback on drafts.

Thanks also to the British Library for both providing scanned facsimile copies of the manuscript parts of Strinasacchi's concerto, and for allowing me to produce a score from those parts for inclusion in this thesis.

To my fellow Masters students (Lynne and Nell in particular) for helping to create an enjoyable, supportive, and stimulating environment, and always being keen for hot chocolate breaks.

And finally to Myren, for patiently listening to me think out loud, helping me solve all the technology problems I encountered at the drop of a hat, and spurring me on through difficult patches. 


\section{Contents}

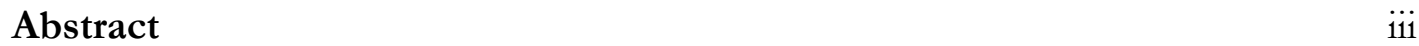

Acknowledgements

List of Illustrations vii

List of Musical Examples viii

Introduction 1

1. "The ear was more gratified than the eye": Problems Surrounding Women and the Violin

Performing, Displaying, and the Male Gaze 7

Class and Gender Associations of the Violin and Its Repertoires 13

Idealisation of Stillness in Women Musical's Performance 16

Physical Movement and the Violin 20

2. "Much delicacy of finger": Conditions which Enabled (Some)

Women to Play the Violin

Familial Support and Access to Education 24

$\begin{array}{ll}\text { Patronage and Employment } & 27\end{array}$

Emulating Men 30

Convents and the Venetian ospedali 35

3. Gender and Gesture in Late Eighteenth-Century Women's Violin

Performance: Regina Strinasacchi's Violin Concerto in B flat major

Analytical Frameworks

Gender and Gesture

Musical Features for Analysis $\quad 50$

Virtuosity 51

Topics $\quad 53$

Structure $\quad 54$

Soloist/Orchestra Interaction 56

Analysis of Strinasacchi's Concerto

I. Allegro Moderato $\quad 57$

II. Adagio 68

$\begin{array}{ll}\text { III. Rondo Affectuoso } & 75\end{array}$ 
Bibliography

Appendix A: List of eighteenth- and early nineteenth-century female violinists

Appendix B: Edited Score of Regina Strinasacchi's Violin Concerto in B flat major

Notes on the Edition

Score 


\section{List of Illustrations}

Figure 1. Hauk, Silhouette of Regina Strinasacchi, 1795 (Klassik Stiftung Weimar, Schloss Tiefurt, Weimar)

Figure 2. Josepha Marti-Zbinden, early nineteenth century (in François de Capitani and Gerhard Aeschbacher, Musik in Bern: Musik, Musiker, Musikerinnen und Publikum in der Stadt Bern vom Mittelalter bis heute (Bern: Historischer Vereins des Kantons Bern, 1993), 182.)

Figure 3. Giovanni Grevenbroch, Orfane filarmoniche, 1754 (in Gli abiti de Veneziani di quasi ogni età, Biblioteca Correr, Venice) 


\section{List of Musical Examples}

I. Allegro Moderato

Example 1.1 Exposition $\quad 60$

Example 1.2 Recapitulation 61

Example 1.3 Vertiginous leaps $\quad 65$

Example 1.4 Vulgar grand cadence 1 66

Example 1.5 Vulgar grand cadence 2 66

II. Adagio

$\begin{array}{ll}\text { Example 2.1 Adagio introduction } & 70\end{array}$

$\begin{array}{ll}\text { Example 2.2 Zefiro topic } & 71\end{array}$

Example 2.3 Vocal-influenced melody $\quad 74$

III. Rondo Affectuoso

$\begin{array}{ll}\text { Example 3.1 Refrain } & 79\end{array}$

Example 3.2 Minore section opening $\quad 81$

Example 3.3 End of minore section 82

Example 3.4 High points of the Rondo 83 


\section{Introduction}

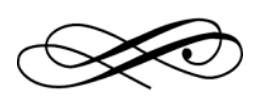

The silhouette reproduced on the title page of this thesis contains a number of curious details, details which cause the viewer to take a second look. A bow on the back of the dress and lace at the cuffs; a music stand with an almost discernible score; and, most striking of all, a woman playing a violin. What makes this image all the more intriguing is that we cannot see her face - the figure is literally a shadow, providing only a vague impression of the person at its centre. The silhouette, made in 1795 and very rare in terms of its subject matter, is of Regina Strinasacchi (1761-1839), an Italian-born and internationally renowned eighteenth-century violinist. ${ }^{1}$ Strinasacchi's silhouette aptly captures the ambiguity and misinformation surrounding women violinists from this era: the fact that they were neglected by histories of music for much of the twentieth century has meant there often remain only tantalising traces of who many of these women were. In this thesis, I have endeavoured to imagine these sometimes indefinite figures as flesh and blood, with a particular focus on considering these female violinists as people who worked within and as a part of society.

Since the introduction of feminism to musicology in the 1990s, women's participation in musical activities, particularly in eighteenth-century Europe, has become an area of much scholarly interest. Most research on this period has concentrated on performers and composers of particular types, namely the numerous singers and keyboard players, and women who wrote for these instruments. This is not surprising, as singing and keyboard playing were musical activities in which the majority of female musicians engaged, and were activities marked as distinctly "feminine" during this period (and indeed later). ${ }^{2}$ The focus on traditionally feminine musical activities has nevertheless had the effect of obscuring the stories of women who played instruments, like the violin, that were considered problematic for their gender. ${ }^{3}$ Despite the

\footnotetext{
${ }^{1}$ Hauk, Silhouette of Regina Strinasacchi, 1795, ink on porcelain, Klassik Stiftung Weimar, Schloss Tiefurt, Weimar. Reproduced from Volker Timmermann, "Strinasacchi, Regina," Sophie Drinker Institut, accessed 8 July 2014, http://www.sophie-drinker-institut.de/cmsms/index.php?page=strinasacchi-regina. 2 Richard D. Leppert, Music and Image: Domesticity, Ideology, and Socio-Cultural Formation in Eighteenth-Century England (Cambridge; New York: Cambridge University Press, 1988), 147; Lucy Green, Music, Gender, Education (New York: Cambridge University Press, 1997), 32-33, 59.

${ }^{3}$ Rita Steblin, "The Gender Stereotyping of Musical Instruments in the Western Tradition," Canadian University Music Review 16, no. 1 (1995): 132-133.
} 
disapproval expressed in conservative sectors, such as feminine conduct literature, a small but significant number of women did play such "unseemly" instruments.

In fact, women violinists turn up at a surprising number of key moments in the history of the violin. Vivaldi, for instance, was able to forge innovations in instrumental music as maestro de' concerti at the Ospedale della Pietà in Venice, where he had access to a uniformly well-trained women's orchestra and collaborations with excellent soloists such as Chiara della Pietà. ${ }^{4}$ According to Simon McVeigh and Jehoash Hirschberg, Vivaldi's L'estro armonico (1711), for example, "changed and shaped the course of instrumental music, through its incisive definition of the concerto idiom and strongly individual characterisation of each concerto". Without this unique environment where female violinists were vital participants, the concerto genre and also violin technique might have developed very differently. In other words, women violinists were essential to the evolution of the concerto as we know it. A second example of women's participation in milestones of violin history relates to the accompanied sonata. This was a favourite genre during the eighteenth-century in which the violin, for the most part, played an unobtrusive supporting role. ${ }^{6}$ One of the first works to really challenge this convention by giving the violin and keyboard equal standing was Mozart's Violin and Keyboard Sonata in B flat major, K. 454, written for the figure from our silhouette, Strinasacchi, and performed by her and Mozart in Vienna's Kärtnertortheater in 1784. It is particularly remarkable that this piece was written for a woman violinist. Not only did the sonata put the instruments on equal footing, it also inverted normative gender roles (male pianist, female violinist), and brought a decidedly domestic genre into a public performance context.

Given the surprisingly frequent involvement of women violinists in events with veritably canonic status, why are these musicians not more widely known? As the above examples hint at, women violinists, when mentioned at all, are usually brought up in relation to "Great Men" narratives: Chiara della Pietà and Vivaldi, Strinasacchi and Mozart, Maddalena Lombardini Sirmen and Tartini - the list goes on. A particular

\footnotetext{
${ }^{4}$ Simon McVeigh, "Concerto of the Individual," in The Cambridge History of Eigbteenth-Century Music, ed. Simon P. Keefe (Cambridge; New York: Cambridge University Press, 2009), 587; Freia Hoffmann, Instrument und Körper: Die musiziererende Frau in der bürgerlichen Kultur (Frankfurt a. M.: Insel Verlag, 1991), $177-$ 178.

${ }^{5}$ Simon McVeigh and Jehoash Hirshberg, The Italian Solo Concerto, 1700-1760: Rhetorical Strategies and Style History (Rochester, NY; Woodbridge, Suffolk, UK: Boydell Press, 2004), 51.

${ }^{6}$ John Irving, "Sonata: 2. Classical," Grove Music Online, Oxford Music Online, Oxford University Press, accessed 7 July 2015, http://www.oxfordmusiconline.com/subscriber/article/grove/music/26191. ${ }^{7}$ Ibid.
} 
anecdote involving Strinasacchi has, for example, often been used to shore up the myth of Mozart's ability to compose in his head (he reportedly had no time to complete the piano part prior to K. 454 's premiere). ${ }^{8}$ In retellings of this kind, her most interesting feature is that she was both a woman and a violinist: her presence seems to function to add novelty to an otherwise well-worn trope. Stories such as this render female violinists passive supporting actors in the lives of others, rather than people with their own stories. Bound up with the issue of "Great Men" narratives, the figure of the female violinist is in conflict with the dominant image of eighteenth-century musical women as non-professional keyboardists and singers.

The combination of these two dominant approaches to discussing female violinists - as novel asides or exceptions to the rule - takes them out of their historical and cultural context, portraying them as isolated and thus dismissible anomalies. This disregards the fact that these women worked as a part of established musical communities and played throughout Europe: in France, Britain, Italian and Germanic states; in the court and church systems; as travelling virtuosi in public and private concerts; as unpaid "amateur" musicians. The participation of women violinists in such diverse contexts shows that, to a certain degree, they were accepted by the societies they worked within (some to a greater degree than others). Otherwise, no female violinist could have had the successful careers experienced by Lombardini Sirmen and Strinasacchi, or indeed any career at all.

Although I discuss a number of female violinists in this thesis, I give particular attention to Strinasacchi. This violinist was an example of how, when certain circumstances aligned, a woman was able to succeed as a professional despite her unusual instrument choice. Strinasacchi was born in Ostiglia (near Mantua) on 18 February 1761, and trained at the Ospedale della Pietà where, as the daughter of professional musicians, she likely attended as a scholarship student. ${ }^{9}$ The length of her stay at the Pietà is unknown, but she was a member of the Pietà's elite musical ensemble known as the coro. ${ }^{10}$ Unlike the majority of ospedali students, Strinasacchi began touring as a soloist while still a teenager, undertaking public performances around Italy and later

\footnotetext{
${ }^{8}$ See, for instance, Frederick George Edwards, quoted in Samuel Breene, "Mozart's Violin Sonatas and the Gestures of Embodiment: The Subjectivities of Performance Practice" (Ph.D. diss., Duke University, 2007), 252-253.

9 Timmermann, "Strinasacchi, Regina".

${ }^{10}$ Jane L. Berdes and Joan Whittemore, A Guide to Ospedali Research (Hillsdale, NY: Pendragon Press, 2012), 810 .
} 
Germany. ${ }^{11}$ After the 1784 tour which saw her perform with Mozart, Strinasacchi returned to Italy in 1785 to marry the German cellist Johann Conrad Schlick, a member of the Gotha court orchestra and secretary to Prince August of Saxe-Gotha-Altenburg. She subsequently became a member of the orchestra there, making her one of the earliest known female orchestral musicians. ${ }^{12}$ This phase of her life - from around 1784 through her early years at the Gotha court - is the period from which much of the information on Strinasacchi in this thesis is drawn. She was resident at Gotha for much of her life, though she and her husband, later accompanied by their daughter Caroline, toured extensively through Germany and Italy playing chamber and solo repertoire. ${ }^{13}$ One of their most frequent destinations was the court of Anna Amalia, a relative to the Prince of Gotha, at Weimar. After Schlick died in 1818, Strinasacchi moved to Dresden with her son Johann Friedrich Wilhelm, a cellist and luthier. It is from this period of her life that the only known example of written correspondence from her comes, a letter in which she informs the recipient that she is well and "continues to make music." ${ }^{14}$ After a long and evidently successful life, she died in Dresden on 11 June 1839.

Strinasacchi is the subject of Chapter Three, where I explore a violin concerto that she composed. In Chapter One, however, I begin with a wider focus, addressing the reasons behind the small number of women players in the eighteenth century. Here I explore issues surrounding eighteenth-century women's musical performance in general, focusing on the concepts of display and the male gaze, a discussion which is informed by Lucy Green's book Music, Gender, Education and inspired by several articles by Suzanne Cusick. ${ }^{15}$ These texts explore how constructions of gender might be expressed through performance. I also draw on Richard Leppert's work regarding music and visual art, where he examines the intertwining issues of music, gender, and sight. ${ }^{16} \mathrm{I}$ build on these texts through an original combination of discussion of display and the

\footnotetext{
${ }^{11}$ Jane L. Berdes, Women Musicians of Venice: Musical Foundations, 1525-1855 (Oxford; New York: Clarendon Press, 1993), 72, 149-150; Timmermann, "Strinasacchi, Regina".

12 "Strinasacchi, Regina".

${ }^{13}$ Ibid.

${ }^{14}$ Breene, "Mozart's Violin Sonatas and the Gestures of Embodiment," 251; Regina Strinasacchi, "Regina Schlick an Luise von Knebel in Jena, Gotha, 5. August 1824," accessed 13 July 2015, http://dme.mozarteum.at/DME/briefe/letter.php?mid=73\&cat=4.

15 Green, Music, Gender, Education; Suzanne G. Cusick, "Performing/Composing/Woman: Francesca Caccini meets Judith Butler," in Musics and Feminisms, ed. Cate Poynton and Sally Macarthur (Sydney: Australian Music Centre, 1999), 79-98; “On Musical Performances of Gender and Sex," in Audible Traces: Gender, Identity, and Music, ed. Elaine Barkin, Lydia Hamessley, and Benjamin Boretz (Zurich; Los Angeles: Carciofoli, 1999), 25-48.

${ }^{16}$ Leppert, Music and Image; The Sight of Sound: Music, Representation, and the History of the Body (Berkeley: University of California Press, 1993).
} 
male gaze with consideration of women's musical performance specifically in an eighteenth-century context. Because of the importance of sight for eighteenth-century audiences of women's performance, I refer to these imagined witnesses as "listener/viewers" throughout, rather than simply "listeners," in order to better reflect the role that the visual played in their experience of performance. An exploration of the associations carried by the violin itself and how those associations problematised violinplaying for women follows the section on display, and Chapter One concludes with a discussion of the physical limits placed on women's musical performance and how violin-playing may have jarred with those limitations. Here I borrow ideas from Matthew Head, Erin Helyard, and Heather Hadlock regarding women's playing of keyboard instruments, applying these ideas to violin performance. ${ }^{17}$

Chapter Two examines the other side of the coin, focusing on the conditions that, despite the difficulties recounted in the previous chapter, enabled some women to play the violin professionally. With reference to research by scholars including Freia Hoffmann and Mai Kawabata, I draw together material from numerous sources on a range of violinists from throughout Europe. ${ }^{18}$ I consider women violinists collectively, not only as individual cases, and in doing so explore similarities in their experiences. I also offer a short section on written reception of certain violinists, specifically looking at how commentators reacted more positively to women violinists who emulated masculine playing styles and dress. Appendix A supplements this chapter by providing a list of the sixty late eighteenth-century women violinists I have researched, and includes date and place of birth and death (where known) as well as key sources for each violinist. The last section of Chapter Two investigates two kinds of institutions - convents and the ospedali - where violin-playing, and importantly ensemble playing, among women was not only sanctioned but nurtured. Here I draw on Berdes's Women Musicians of Venice, as well as work on convent musicians by scholars such as Colleen Baade, who

\footnotetext{
17 Matthew Head, Sovereign Feminine: Music and Gender in Eighteenth-Century Germany (Berkeley: University of California Press, 2013); Erin Helyard, "Muzio Clementi, Difficult Music, and Cultural Ideology in Late Eighteenth-Century England” (Ph.D. diss., Schulich School of Music, McGill University, 2012); Heather Hadlock, "Sonorous Bodies: Women and the Glass Harmonica," Journal of the American Musicological Society 53, no. 3 (2000): 507-542.

${ }^{18}$ Hoffmann, Instrument und Körper, Maiko Kawabata, Paganini: The 'Demonic' Virtuoso (Woodbridge, Suffolk; Rochester, NY: The Boydell Press, 2013); "Virtuoso Codes of Violin Performance: Power, Military Heroism, and Gender (1789-1830),” 19th-Century Music 28, no. 2 (2004): 89-107.
} 
have demonstrated that nun and ospedali musicians can in fact be seen as professional musicians. ${ }^{19}$

The final chapter puts the spotlight on Strinasacchi's Violin Concerto in B flat major, the score of which is presented in Appendix B. To my knowledge, this is the first in depth analysis of a composition by a female violinist since Berdes's edition of three concertos by Lombardini Sirmen was published in $1991 .^{20}$ Issues broached in the previous chapters, including gender and the sight of the performing body, are key features of the analysis, and I draw on accounts of women violinists in support here. My analysis has been informed by George Fisher and Judy Lochhead's article "Analyzing from the Body" and Elizabeth Le Guin's Boccherini's Body, as well as work by Helyard and Tia DeNora. ${ }^{21}$ I combine various aspects of these "embodied musicology" studies by exploring the key issues of gender and gesture in relation to late eighteenth-century women's violin performance. I therefore concentrate on musical features which interact with gender and physical movement in interesting ways, here resulting in a focus on virtuosity, topics, structure, and the interaction between soloist and orchestra.

Through considering the varied experiences of these women violinists, this thesis challenges the ubiquity of the amateur female keyboardist figure, suggesting that being a female musician in eighteenth-century Europe encompassed a much wider range of experiences. Though we can only gleam a limited idea of how contemporaneous audiences responded to these women in performance, my discussion of Strinasacchi's concerto seeks to consider how her transgressive gestures may have shaped their reception. In doing so, this concerto emerges as a useful tool through which to consider the roles that female violinists more generally played within their historical and cultural context. A further aim of this thesis is to present these women as the lead actors in their own stories, rather than indistinct background figures in someone else's master narrative, challenging the tendency to treat female violinists as novelties useful only for spicing up footnotes.

\footnotetext{
${ }^{19}$ Berdes, Women Musicians of Venice; Colleen Baade, "Hired' Nun Musicians in Early Modern Castile," in Musical Voices of Early Modern Women: Many-Headed Melodies, ed. Thomasin K. LaMay (Aldershot; Burlington: Ashgate, 2005), 287-310.

20 Maddalena Laura Lombardini Sirmen, Three Violin Concertos, ed. Jane L. Berdes (Madison: A-R Editions, 1991).

${ }^{21}$ George Fisher and Judy Lochhead, “Analyzing from the Body," Theory and Practice 27(2002): 37-67; Elisabeth Le Guin, Boccherini's Body: An Essay in Carnal Musicology (Berkeley: University of California Press Berkeley, 2006).
} 


\section{Chapter One}

\section{8 \\ "The ear was more gratified than the eye": Problems Surrounding Women and the Violin}

Before addressing the question of how some women were able to build careers as violinists, it is necessary to look at what factors made it difficult for women and girls to take up the instrument in the first place. This necessitates an exploration of some of the typical or stereotypical expectations held in the eighteenth century with regards to women and their actions. It is important to note that not everyone held these expectations to be valid - no woman would have picked up a violin at all if that had been the case. So while I do not emphasise dissenting views in this chapter, they were undoubtedly present. Indeed, the outcomes of resistance to the ideals surrounding women's music-making by female violinists will be explored more thoroughly in Chapter Two.

In this chapter, I look at general attitudes toward performing women in the eighteenth and early nineteenth centuries. A woman presenting her body in performance was seen as fulfilling the "feminine" role of displayer (as opposed to the "masculine" role of viewer) and perceived as potentially morally dubious. These issues are complicated by the performer's social class. I then address associations of the violin itself in terms of class and gender. Thirdly, I examine the physical restrictions that middle- and upper-class women faced, considering how the male gaze influenced women's musical performance and how the physical requirements of the violin may have clashed with these. There were quite a number of factors inhibiting women from playing the instrument, so it is not surprising that those who did were in the minority.

\section{Performing, Displaying, and the Male Gaze}

For most of the eighteenth century, European women of the middle and lower classes participated relatively widely in the world of paid work. Within the music 
industry they worked alongside male family members in publishing and instrument making as well as in performance as singers and instrumentalists. ${ }^{1}$ By the end of the century, however, women were increasingly excluded from participating in working life, deemed part of the newly articulated public sphere. ${ }^{2}$ While it had long been considered inappropriate for upper-class women to undertake paid work - their very ability to disengage from labour was symbolic of their male relatives' wealth - it was now also problematic for middle-class women to do so. ${ }^{3}$ Not all eighteenth-century music commentators held the view that women should not work outside the home, but this ideology did affect professional women musicians, making performing for pay an area of contention. ${ }^{4}$ Changes in attitudes toward women and work were influenced by figures such as Rousseau. According to Rousseau, women needed first and foremost to fulfil their "natural" roles as mothers and wives within the newly-feminised domestic sphere: women who subverted these confining gender roles, such as upper-class society women and lower-class actresses, were characterised as immoral. ${ }^{5}$ The commonality between these two groups of women was that they put themselves - their intellect, but also their bodies and sexuality - on display in public. ${ }^{6}$ The power of feminine sexuality was the most dangerous aspect of displaying women in both theatrical and nontheatrical situations, as Rousseau believed that the act of watching a seductive woman robbed men of their masculinity and thus their power. Paid performing women were thus doubly threatening, as they not only earned their own income but did so directly in the public eye. They were not only individually dangerous for men in the audience but symbolically threatening to the (patriarchal) social order. ${ }^{7}$ Nevertheless, the lack of political and economic agency women in general possessed outside the theatre indicates that the power Rousseau ascribed to displaying women was somewhat illusory.

\footnotetext{
${ }^{1}$ Valerie Woodring Goertzen, "The Eighteenth Century," in From Convent to Concert Hall: A Guide to Women Composers, ed. Sylvia Glickman and Martha Furman Schleifer (Westport, Conn: Greenwood Press, 2003), 91.

${ }^{2}$ Cecilia Feilla, "Regarding Women: The Politics of Beholding in Rousseau's Letter to M. d'Alembert on the Theatre," Women \& Performance: A Journal of Feminist Theory 7, no. 1 (1994): 3.

${ }^{3}$ Leppert, Music and Image, 67.

${ }^{4}$ Professional women musicians were generally of the lower middle class. Nancy B. Reich, "Women as Musician: A Question of Class," in Musicology and Difference: Gender and Sexuality in Music Scholarship, ed. Ruth A. Solie (Berkeley: University of California Press, 1995), 125-126; David Gramit, Cultivating Music: The Aspirations, Interests, and Limits of German Musical Culture, 1770-1848 (Berkeley: University of California Press, 2002), 115-116.

${ }^{5}$ Actresses were routinely compared to prostitutes. Feilla, "Regarding Women," 3-4.

${ }^{6}$ Jean-Jacques Rousseau, Letter to D'Alembert and Writings for the Theater, ed. Allan Bloom, Charles E. Butterworth, and Christopher Kelly (London: University Press of New England, 2004), 286-287.

${ }^{7}$ Feilla, "Regarding Women," 4-5.
} 
Though Rousseau did not mention female musicians in his writing, there were similar issues at play with female singers and instrumentalists as there were with actresses, and Rousseau's arguments were later explicitly extended to professional women musicians by German writers such as Johann Bernhard Basedow and Joachim Heinrich Campe in the late 1770 s. ${ }^{8}$ Richard Leppert highlights the visibility of female performers as key to the threat they were perceived to pose: by performing publically a woman risked "upstaging her husband" and communicating that she had shunned her expected role as subservient wife. ${ }^{9}$ Implicit in Leppert's discussion is the upper-class status of the performer. Performing publically, even if the performer received no remuneration, was fraught for all women, but it was particularly problematic for upperand aspiring upper- and middle-class women.

In Music, Gender, Education, Lucy Green foregrounds this issue of bodily display in relation to musical performance and gender. A key point she broaches is that the concept of "display" itself has strong gender associations: display is typically seen as a feminine action, while viewing is masculine. ${ }^{10}$ Green's argument engages with cinema theorist Laura Mulvey's concept of the male gaze: through being observed, women are rendered passive objects. ${ }^{11}$ Though some scholars have argued that it is ahistorical to apply the male gaze concept to eighteenth-century issues, I feel that Green's interpretation of the male gaze is still a useful tool for exploring eighteenth-century women's musical performance, primarily because the aims and limits of women's performance were so frequently dictated by male interests within the highly patriarchal system that was Europe at this time. ${ }^{12}$ Green not only applies Mulvey's theories to women's musical performance in various contexts and eras but also builds on them. She posits that in comparison to actresses on film, female musicians in live performance have greater control and thus greater power in their displaying, primarily because they are the active source of musical sound. ${ }^{13}$ She also discusses display and gender in relation to both female singers and instrumentalists, making a number of distinctions between the two groups. Green argues that, as singing is an "integrated" activity - that is, the body and the "instrument" (voice) are unified - there is a significant aspect of

\footnotetext{
8 Reich, "Women as Musician," 133.

9 Leppert, Music and Image, 39-40.

${ }^{10}$ Green, Music, Gender, Education, 25, 29.

${ }^{11}$ Laura Mulvey, "Visual Pleasure and Narrative Cinema," in Visual and Other Pleasures (New York: Palgrave Macmillan, 2009), 14-27.

12 Rivka Swenson, "Optics, Gender, and the Eighteenth-Century Gaze: Looking at Eliza Haywood's AntiPamela," Eighteenth Century Eighteenth Century 51, no. 1-2 (2010): 29-32.

13 Green, Music, Gender, Education, 26-27 n5.
} 
display to a performance by a singer. ${ }^{14}$ One cannot help but focus on the body: it is the origin of the sound. The integrated and fully embodied nature of the act of singing also reinforces the traditional association of women with the natural world and indeed with the very concept of music. ${ }^{15}$ In this way, a female singer is more liable to be objectified - rendered passive - by the male gaze than a woman engaged in other kinds of musical performance. As such, a singing woman might still in fact "affirm her femininity" as a subordinate participant in a patriarchal system. ${ }^{16} \mathrm{~A}$ singing woman thus posed less of a challenge to male power than did certain kinds of instrumentalists, like violinists.

Instrumentalists can pose a challenge to patriarchal roles through the mediating influence of their instrument. In other words, playing an instrument can enable resistance to the male gaze. According to Green, playing an instrument "interrupts" display because it draws attention away from resting solely on the body (though this is less the case with instruments that are strongly associated with the feminine, such as keyboards). ${ }^{17}$ Not being able to focus solely on the body as object reduces the level of pleasure available to the viewer. She suggests that instrumental performance is to a certain extent characterised as a masculine activity, because the display element is decentralised, and because the instrumentalist is shown to exhibit control over a piece of technology. ${ }^{18}$ Control over something external to the body is a strongly masculinegendered act. ${ }^{19}$ Technology, such as a musical instrument, is used by men to control nature (here sound/music) and is a privilege theoretically closed to women, as in this ideology women are aligned with nature and are thus subject to control, not exercisers of it. There were, however, instruments such as plucked strings, harp, and various kinds of keyboards which were deemed suitable for women. ${ }^{20}$ While plucked strings are obviously "feminine" in their softness of volume and small size, large and

\footnotetext{
${ }^{14}$ Ibid., 28.

${ }^{15}$ Susan McClary, Feminine Endings: Music, Gender, and Sexuality (London; Minneapolis: University of Minnesota Press, 2002), 17.

${ }^{16}$ Green, Music, Gender, Education, 28-30, 35-36. This is not to say that singing women are necessarily rendered powerless. Texts which explore singing women's resistance include Carolyn Abbate, “Opera; Or, the Envoicing of Women," in Musicology and Difference: Gender and Sexuality in Music Scholarship, ed. Ruth A. Solie (Berkeley: University of California Press, 1993), 225-258; Elizabeth Wood, "Sapphonics," in Queering the Pitch: The New Gay and Lesbian Musicology, ed. Philip Brett, Elizabeth Wood, and Gary Thomas (New York: Routledge, 2006), 27-66; Suzanne G. Cusick, Francesca Caccini at the Medici Court: Music and the Circulation of Power (Chicago: University of Chicago Press, 2009).

${ }_{17}$ Green, Music, Gender, Education, 52-53.

18 Ibid., 53.

${ }^{19}$ See Cusick, "On Musical Performances of Gender and Sex," 36.

${ }^{20}$ Steblin, "The Gender Stereotyping of Musical Instruments," 138, 136.
} 
technologically complex keyboards seem to contradict their gender designation. ${ }^{21}$ The femininity of keyboards instead stemmed from their extensive domestic use, role as accompaniment instruments, and the fact that they could be played in a visually appealing manner (more on this later). ${ }^{22} \mathrm{~A}$ woman playing an instrument which did not have these "feminine" characteristics - indeed if it was considered to be masculine (as we shall discover is the case with the violin) - was considered to be taking control of technology inappropriate for her gender, thus impinging upon male power and disrupting display.

By contrast, Erin Helyard's work on women's performance of difficult keyboard music takes a different view of women, instruments, and display. He suggests that virtuosic (which often means highly physical) music in fact focused viewers' attention more readily on the performer's body movements, which became eroticised through such subversive performance. ${ }^{23}$ Though Helyard is of course discussing a feminine instrument, which reduces the intensity of the technological disruption, the point that virtuosic music can draw attention to the body even when tempered by an instrument hints at a contradictory situation for women violin players, in which attention is concomitantly displaced from the body by the instrument and centred on the body by the dynamic physical movement that instrument affords.

Male interests and the male gaze were an important part of eighteenth-century women's musical performance. Though contemporaneous writers on education and conduct proposed that practising music within the home could prevent boredom and foster discipline in young girls, performance carried a different purpose. ${ }^{24}$ This was perhaps especially the case in the second half of the century as musical performance came under the "accomplishment" model of upper- and middle-class female education. Young women cultivated accomplishments (needlework, dancing, polite conversation) with the express purpose of appealing to potential suitors. Of all the accomplishments, music was deemed particularly useful as a method of attracting a husband as "it could be shown off best while actually being accomplished." 25 As an accomplishment which had a visible effect upon the body, women's musical performance thus often played directly to the gaze of male viewers in the hope of eliciting a proposal.

${ }^{21}$ Ibid., 139; Green, Music, Gender, Education, 59.

22 Music, Gender, Education, 59.

${ }^{23}$ Helyard, "Muzio Clementi, Difficult Music, and Cultural Ideology," 68.

${ }^{24}$ Leppert, The Sight of Sound, 67-68.

25 Arthur Loesser, Men, Women, and Pianos: A Social History (New York: Simon and Schuster, 1954), 268. 
Singing or playing certain instruments did not just display a woman's personal attributes: it also served to display her family's - thus her father's - material and cultural wealth. Through performance she showed that her family could afford lessons and an instrument (singers obviously excepted), and that they had the social standing to appreciate such things. Keyboard instruments were particularly well suited to this purpose, as even when not being played they still fulfilled the function of visually communicating the wealth and status of their owner through their size and elaborateness, on display in public rooms of the house. ${ }^{26}$ Violins - often much cheaper and certainly easier to store than keyboards - were possessed by people of varied socioeconomic status, including lower class and marginalised groups like the Roma (pejoratively called "gypsies"). Some violins were decorated with elaborately carved scrolls or even painted bodies but this could not compare with the potential for decoration offered by a keyboard. Violins thus carried little of the cultural capital inherent particularly in large keyboard instruments. ${ }^{27}$

Women's musical performance can thus be seen as part of economic exchange between men: it was a method by which potential buyers (husbands) could be encouraged to purchase (marry), and as such constituted an "investment" on the part of fathers. ${ }^{28}$ Jean Marsden has explored this idea in relation to actresses and the gaze on the English stage, pointing out that "in a social system that had already identified women as commodities for homosocial exchange... the actress presented an opportunity for visual representation of this exchange." ${ }^{29}$ Replace "actress" with "female musician" and this phrase encapsulates a key expectation - though not necessarily always the reality in practice - underlying women's musical performance. Within this world view, many eighteenth-century Europeans expected women's musical performance to provide aural and indeed visual pleasure for those witnessing it. Regula Hohl Trillini has also pointed out that the sight of the female performer may in practice have played a larger role in the male listener/viewer's ability to take pleasure in women's performance than one might think. Many men had little knowledge or interest in music

\footnotetext{
${ }^{26}$ Leppert, Music and Image, 154.

${ }^{27}$ Helyard, "Muzio Clementi, Difficult Music, and Cultural Ideology," 161.

${ }^{28}$ Leppert, Music and Image, 29. See also Luce Irigaray, "Women on the Market," in This Sex Which Is Not One (Ithaca, NY: Cornell University Press, 1985), 170-191.

29 Jean I. Marsden, Fatal Desire: Women, Sexuality, and the English Stage, 1660-1720 (Ithaca, NY: Cornell University Press, 2006), 9.
} 
due to the fact that they typically received little or no training in it and were therefore likely to place their focus on the visual elements of a performance. ${ }^{30}$

Class and the issue of remuneration clearly interact with the issues of display and the male gaze. Though both paid and unpaid performers can of course be objectified by the viewer, the unpaid performer is in some ways more tightly bound to the expectation that they will provide pleasure. This is because of a difference in aims between each mode of performance. The ostensible aim of unpaid performance is to communicate the player's status and secure a husband, thus the performance will not fulfil its function if the musician subverts the viewers' expectations through performing in a visually unattractive manner. Alternatively, with paid performance, while it may be in the performer's best interest to appeal to the male gaze, she may also build a career on not doing so: infamy (up to a point) sells just as many tickets. And importantly, the primary goal of professional performance is to provide income for the performer, allowing her an independent means to support herself which is unavailable to a compulsorily leisured woman. This is significant as receiving payment for performance renders it useful, the very "non-productiveness" of unpaid musical performance being what made it a prestigious activity for upper-class women. ${ }^{31}$ This may help explain why so few unpaid upper-class women appear to have played the violin, in comparison to those from middle-class/professional music backgrounds.

\section{Class and Gender Associations of the Violin and Its Repertoire}

The fact that instrumental performance posed greater problems for women than singing did (due to the interrupting effect an instrument can have on the gaze and thus the pleasure of the audience) is an issue that is clearly relevant to the violin. Moreover, the violin and certain repertoires for it had a number of additional unsavoury associations involving class and gender that rendered it even more problematic for women. The violin had been widely used throughout Europe in folk traditions and was thus linked with the lower and peasant classes, only becoming an appropriate instrument for gentlemen players in the seventeenth century. ${ }^{32}$ This use continued through the eighteenth and nineteenth centuries, with the Bierfiddler figure and the

\footnotetext{
${ }^{30}$ Regula Hohl Trillini, The Gaze of the Listener: English Representations of Domestic Music-Making (Amsterdam; New York: Rodopi, 2008), 215.

${ }^{31}$ Leppert, Music and Image, 28-29, 200.

32 The Sight of Sound, 34.
} 
instrument he played carrying connotations of vagrancy and immorality. ${ }^{33}$ The easy portability of the violin perhaps helped to maintain its itinerant and thus suspect reputation: certainly it contrasted with the immobility of large keyboards, whose size and weight perhaps projected the impression of their owners' rootedness or permanence. Violins were also an essential element of dance music and were often played by dancing masters. ${ }^{34}$ As dancing masters were often of low birth yet taught aristocratic skills to young female students, they were satirised (especially in England) as lecherous and with aspirations above their station. ${ }^{35}$ Building further on the connection with dance, the violin had consistently been depicted as the instrument of the devil in visual art from the mid-sixteenth century onwards. ${ }^{36}$ This derived from perceptions that dancing was sinful, the view taken by many religious institutions, which lent the instrument a sinister and depraved air. If playing an instrument was intended to improve or at least shore up a young woman's social status then the lower-class status and sinful connotations of the violin rendered it an undesirable choice.

In addition to these class associations, the violin was considered a "masculine" instrument during the late eighteenth century, though most sources do not elaborate upon what that might mean beyond the fact that it was predominantly played by men. The instrument itself was frequently discussed in gendered and sometimes personified terms. For instance, perhaps due to the prominence accorded the violin by Louis XIII through his employment of the Vingt-quatre Violons du Roy, the violin was often called the "king of instruments," associating it with royalty and despotic masculinity. ${ }^{37}$ This reputation was reinforced as courts throughout Europe began to establish violindominated ensembles which only employed men, which in turn marked the fledgling concept of the orchestra and its repertoire as masculine. In its role as a gentleman's instrument in the second half of the eighteenth century the violin participated in the even more obviously gendered genre of the accompanied sonata. This genre was closely associated with courtship, with the keyboard played by an unmarried woman and the violin by her suitor: as such it was considered to be highly intimate. ${ }^{38}$ The connotations of courtship add another layer of subversion to the dynamic of Mozart's K. 454 sonata:

\footnotetext{
33 Kawabata, Paganini, 61.

${ }^{34}$ Leppert, Music and Image, 78-88.

35 Paula Gillett, Musical Women in England, 1870-1914: "Encroaching on All Man's Privileges" (New York: St. Martin's Press, 2000), 90.

${ }^{36}$ Ibid., 88.

${ }^{37}$ John Spitzer and Neal Zaslaw, The Birth of the Orchestra: History of an Institution, 1650-1815 (Oxford; New York: Oxford University Press, 2005), 72.

${ }^{38}$ Helyard, "Muzio Clementi, Difficult Music, and Cultural Ideology," 180-182.
} 
having a female violinist fulfil the role normally taken by a male suitor would appear to pose a serious challenge to the patriarchal status quo. Strinasacchi not only took on a decidedly masculine role, but (as previously mentioned) one that was musically assertive. Even without the particular subversions of K. 454, the sexually charged nature of the genre may have made the accompanied sonata fraught territory for female violinists.

Seeing the violin as gendered and person-like was a concept that had increased in popularity by the end of the eighteenth century. By Paganini's day a change had taken place in the assigned gender of the instrument - violins were no longer likened to kings but to female singers. ${ }^{39}$ According to Kawabata, this is due both to the similarity in register between the violin and the female singing voice, but also because of the visual comparison between the instrument's hourglass-shaped "body" and that of the female figure. ${ }^{40}$ It is unclear when exactly this change in gendering of the violin as an instrument came about, though it seems to have increased in popularity after the rise of the military violin concerto and the concept of the heroic, Napoleonic violinist in Revolutionary-era Paris, an image advanced by violinist-composers such as Pierre Baillot, Pierre Rode, and Rudolphe Kreutzer. ${ }^{41}$ Kawabata states that "inherent in the idea of the 'heroic' violin performance was the player's masculinity," symbolised most palpably by his use of recently invented sword-like Cramer and Tourte bows. ${ }^{42}$ The straighter line of these bows and the more powerful, and indeed violent, strokes they afforded in comparison to earlier models elicited phallic associations, most apparent in responses to Paganini's playing, where his furious playing style was described as sexualised attack made against the feminine violin. ${ }^{43}$ Hoffmann (on whom Kawabata draws) has also suggested that a woman playing the violin in this context carried connotations of lesbianism: the interaction of gendered-female human body and gendered-female violin "body" in a public setting supposedly evoked an "unconscious" (unbewn $\beta t$ ) association of illicit female relations for eighteenth-century audiences. ${ }^{44}$

The most explicitly gendered concepts - of the violin as feminine and the violinist as heroically masculine - can only be confirmed as widespread after the turn of the century. Prior to this, the assumption was that the violin was a pursuit to be undertaken

\footnotetext{
${ }^{39}$ Kawabata, Paganini, 59.

40 Ibid., 58-59.

41 "Virtuoso Codes of Violin Performance," 97.

42 Ibid., 104.

43 Ibid., 103-105.

${ }^{44}$ Hoffmann, Instrument und Körper, 190.
} 
by men only, encapsulated by comments such as Leopold Mozart's recommendation to "always play with earnestness and manliness." 45 This shows that women and the feminine had little or nothing to do with the instrument in most listeners' minds, often resulting in confusion and sometimes antipathy when a woman assumed that role. ${ }^{46}$ Even when the instrument came to be directly connected with women and femininity, the particular nature of this gendering still resulted in exclusion of actual women, and it seems possible that a sense of anxiety around the use of the violin by women may have been heightened once the violin was explicitly cast as a feminised "body." The lowerclass and immoral associations of the instrument persisted into the eighteenth century parallel with its developing role as a gentleman's hobby, which likely led to a further sense of breached decorum when it was played by a woman. Thus, although understandings of the violin changed over time, discourse about the instrument was perpetually tied to ideas about gender and class which significantly complicated its use by women.

\section{Idealisation of Stillness in Women's Musical Performance}

The associations discussed above would have been on most listener/viewers' minds when witnessing a female violinist perform. In eighteenth-century commentaries on these musicians, however, it is not these connotations that are mentioned as the source of the transgression, but rather their physical bodies: the requirements of violinplaying appear to have clashed with ideas about women's physical movement. Nonworking middle- and upper-class women faced a host of restrictive expectations about their physical movement during the eighteenth century. These expectations connected with the belief that women were naturally intended to be passive members of society, while men were naturally active, but really this was about controlling the threat many men perceived in the concept of an active woman. ${ }^{47}$ From a young age, girls were prepared for leading a sedentary adult life and expected to occupy themselves with

\footnotetext{
${ }^{45}$ Quoted in Kawabata, "Virtuoso Codes of Violin Performance," 104. This pure, "manly" tone was contrasted with excessive use of vibrato, which (through its negative associations with weakness and positive associations with sweetness) was viewed as feminine. Tone and vibrato are therefore yet further examples of musical features that were perceived as gendered during the eighteenth century. My thanks to Erin Helyard for drawing my attention to the gendering of vibrato during this period. See Greta MoensHaenen, "Vibrato," Grove Music Online, Oxford Music Online, Oxford University Press, accessed 6 February 2016, http://www.oxfordmusiconline.com/subscriber/article/grove/music/29287.

${ }^{46}$ Gillett, Musical Women in England, 78.

${ }^{47}$ Green, Music, Gender, Education, 14-15.
} 
docile pursuits: thus the only two forms of overt physical movement deemed appropriate were walking and dancing. ${ }^{48}$ Clothing was another means by which women were physically restrained, to a much greater extent than men, through the use of items such as stays (a predecessor of the corset).

This prioritisation of stasis delineated which musical activities were generally deemed appropriate for women and how they should be executed. ${ }^{49}$ All eighteenthcentury instruments considered appropriately feminine held in common the trait that they could be played with minimal physical movement and maximum physically visible ease. In other words, when played in officially sanctioned (read: confined) ways, physically quiet instruments like keyboards and plucked strings affirmed the femininity of their performers. By comparison, the dynamic physical movement that the bow arm in particular often demands placed the violin outside the limits of acceptable performance. Likewise, contortion of the face caused by the use of the mouth in brass and woodwind playing meant that these instruments were considered even less appropriate for women than the violin. ${ }^{50}$ Affirmation of femininity in this context meant pleasing the male gaze by upholding the patriarchal conception of woman as passive object, available to be visually consumed, and it also involved adhering to eighteenth-century expectations regarding physical gracefulness. The concept of gracefulness was informed by the ideal of sprezzatura ("studied nonchalance") and inherently associated with the aristocracy, a physical communication of one's rank. ${ }^{51}$ According to Eric McKee, who discusses gracefulness in relation to the minuet, gracefulness involved such features as "simplicity... tranquillity; small inflections of the body; delicacy of attitude and motion; roundness of motion; weightlessness; restraint and hidden control". ${ }^{52}$ In this conception of grace, energetic physical movement or anything that was perceived to be laborious, appeared uncouth. Looking uncouth inhibited the possibility of the performer being perceived as desirable passive object. The concept that energetic movement was coarse ties back to the idea that to be perceived as doing something approximating work - such as exerting the body in

\footnotetext{
${ }^{48}$ Leppert, Music and Image, 69; Julia Allen, Swimming with Dr Johnson and Mrs Thrale: Sport, Health and Exercise in Eighteenth-Century England (Cambridge: Lutterworth Press, 2012), 120, 129.

${ }^{49}$ Leppert, Music and Image, 39.

${ }^{50}$ Woodwind instruments also carried phallic connotations. Hoffmann, Instrument und Körper, 190; Vanessa M. Tonelli, "Women and Music in the Venetian Ospedali" (master's thesis, Michigan State University, 2013), 37.

51 "Sprezzatura," accessed 13 July 2015, http://www.merriam-webster.com/dictionary/sprezzatura; Head, Sovereign Feminine, 62.

52 Adapted from table 2.2 in Eric McKee, Decorum of the Minuet, Delirium of the Waltz: A Study of Dance-Music Relations in 3/4 Time (Bloomington: Indiana University Press, 2012), 62.
} 
vigorous musical performance, as required in violin-playing - was degrading for upperand upper-middle-class women. ${ }^{53}$

The idealisation of stasis can be seen at work in relation to a uniquely eighteenthcentury instrument: the glass armonica. Heather Hadlock has suggested the armonica was considered the epitome of feminine music-making because it required so little physical effort to play. She argues that "to play the armonica was to hold a pose, to present a performance of stillness, balance, and silence. Playing, in short, resembled the "not-playing" depicted in so many contemporary paintings of women seated at keyboard instruments, touching but not pressing the keys." ${ }^{54}$ Important in relation to our focus on the male gaze, she posits that "the instrument reconciled potentially contradictory desires: to hear women making music and to see them in a relaxed and graceful attitude. ${ }^{, 55}$ This highlights that the sight of women performing was a crucial element of their music-making, but it also shows that the ideal of musical woman as object (epitomised by an actual object, the portrait) was essentially unobtainable. The violin provides a palpable contrast to the armonica: the movements required to play the violin, even quietly, are almost antithetical to this ideal of motionlessness. The combination of pressure and speed of bow are basic tenets of sound production on the violin, meaning that obvious movement of the right arm is unavoidable. In a discussion of late seventeenth-century Dutch landscape painting including musical scenes, Leppert also mentions that the violin's relationship to dance and the peasant classes led to its association with "intense physicality" and "frenetic movement". ${ }^{56}$ Meanwhile the armonica was strongly associated with hypnosis and the attendant connotations of spiritual disembodiment. ${ }^{57}$ The potential for dynamism, the "frenetic movement" of both the bow arm and the left hand (particularly in fast, detached passages), and the physical movement that the instrument inspired in other bodies (toe tapping, clapping, dancing), sets the armonica and the violin at opposite ends of the kinetic scale.

A second example involving the stillness ideal and musical performance shows that composers and performers were acutely aware of the requirements. In a letter to Haydn dated 11 July 1790, keyboardist Maria Anna von Genzinger requested that the composer change a left-over-right hand crossing in the Adagio of the Sonata in E flat,

${ }^{53}$ Head, Sovereign Feminine, 61-62.

${ }^{54}$ Hadlock, "Sonorous Bodies," 511.

55 Ibid.

${ }^{56}$ Leppert, The Sight of Sound, 34.

${ }^{57}$ Hadlock, "Sonorous Bodies," 534. 
Hob. XVI:49, because of the bodily and therefore visual affect this would have in performance. ${ }^{58}$ Tom Beghin notes that this passage (mm. 57ff.) "requires a contortion of arms and body that any well-postured, right-handed noble woman would have resisted. ${ }^{, 59}$ Left-handedness was treated with suspicion during the eighteenth century, so the attention-grabbing movement of crossing the left arm over the right may have been perceived as particularly ugly in its conspicuousness. Most importantly, this passage of the Adagio is offensive because it draws undesirable attention to the performer's body, which interferes with her ability to affirm her femininity through musical performance - hence Genzinger wanted it removed.

The Genzinger example of course illustrates that the concept of physical containment was not just a feature of feminine instruments, but of much of the repertoire women played. As Matthew Head discusses, a portion of keyboard repertoire targeted at women during this period was intentionally physically and musically "easy.",60 Because of this, restricting movement to her arms, wrists, and fingers while at the keyboard would not have prevented a musician from playing much popular music of the day to a standard considered acceptable. Sources such as Erasmus Darwin's A Plan for the Conduct of Female Education (1797) show that being too proficient a performer (for instance by playing advanced pieces which might require physical contortions, such as hand crossing or large intervals, was thought to indicate that the performer had ignored more important aspects of her education. ${ }^{61}$ Helyard has also shown that women's performance of difficult keyboard music was linked by critics to vanity when modesty was stressed as an important feminine quality. ${ }^{62}$ This means that a musically or technically flawed player who looked appealing while performing simple music was often valued more highly than her peer who could play difficult music well and yet used her body more vigorously, and thus "inappropriately."

\footnotetext{
58 Breene, "Mozart's Violin Sonatas and the Gestures of Embodiment," 229-230.

59 Tom Beghin, “A Composer, His Dedicatee, Her Instrument, and I: Thoughts on Performing Haydn's Keyboard Sonatas," in The Cambridge Companion to Haydn, ed. Caryl Leslie Clark (Cambridge: Cambridge University Press, 2005), 222.

${ }^{60}$ Head, Sovereign Feminine, 49, 66-68. Both Head and Helyard have discussed at length that, despite the existence of "easy" music, women players could and did resist. Helyard, "Muzio Clementi, Difficult Music, and Cultural Ideology," 78, 97, 100-102.

${ }^{61}$ Quoted in Leppert, The Sight of Sound, 68.

${ }^{62}$ Helyard, "Muzio Clementi, Difficult Music, and Cultural Ideology," 90.
} 


\section{Physical Movement and the Violin}

Eighteenth-century observers of women violinists often communicated that the physical movements required to play the violin were, at best, unattractive, at worst, offensive. The English oboist William Parke, for example, commented on the displeasing sight of Louise Gautherot performing on two separate occasions. In 1789 he stated that Gautherot performed "with great ability" but that "the ear... was more gratified than the eye by this lady's masculine effort." ${ }^{\text {"63 }}$ In relation to a 1790 performance he commented: "it strikes me that if [Gautherot] is desirous of enrapturing her audience, she should display her talent in a situation where there is only just enough light to make 'darkness visible." ${ }^{64}$ Further examples include those found in a 1784 essay by cleric and music commentator Carl Ludwig Junker. Junker believed that the combined impact of women's clothing and inappropriate physical movement had a negative effect upon the audience's ability to enjoy the music when female violinists played, stating further that "we have a certain feeling of impropriety, that, as it seems to me, weakens the effect of the piece that is performed. This arises from ideas of bodily movement joined to the characteristic dressing style of the second sex." ${ }^{\prime 65}$ Less than two decades later, philosopher Karl Heinrich Heydenreich argued that "to play on the violin or organ is not compatible with the grace of the female sex... The arm movements which violin players must make and the faces which they pull would do unfailing harm to femininity." ${ }^{\prime 66}$ What Parke, Junker, and Heydenreich were reacting to was the disruption of their ability to take pleasure in the musical female body: the physical movements women violinists made shattered the possibility of "consuming" their bodies as objects. ${ }^{67}$

Despite the fact that these statements single out physical movement as the key issue, Paula Gillett argues that such objections to the sight of female violinists were merely rationalisations for the discomfort commentators experienced. She suggests this primarily because writers like Parke and Junker are vague about the specific movements

${ }^{63}$ William Thomas Parke, Musical Memoirs: Comprising an Account of the General State of Music in England, from 1784, to the year 1830 (London: H. Colburn and R. Bentley, 1830), 120.

64 Ibid., 129-130.

${ }^{65}$ My italics. Quoted in Sanna Iitti, The Feminine in German Song (New York: Peter Lang, 2006), 35.

${ }^{66}$ Quoted in Steblin, “The Gender Stereotyping of Musical Instruments,” 138.

${ }^{67}$ Further examples of statements such as those above include the following. For Hans Georg Nägli regarding women violinists generally (1826) see Hoffmann, Instrument und Körper, 190. In a review of Giulia Paravicini (October 1830) see Kawabata, "Virtuoso Codes of Violin Performance," 105 n66. 
that might have caused offense. ${ }^{68}$ Instead, Gillett posits that the underlying association with immorality was what really made the instrument problematic for women. ${ }^{69}$ She points out that women who played other bowed string instruments did not prompt the same response: it was specifically the violin as an instrument that caused the objection. ${ }^{70}$ While the instrument's connection to sin and the lower classes played a significant role in preventing women from playing it, the idea that the physical movements themselves were transgressive should not be so easily dismissed.

Bowed strings played in the lap or placed between the knees such as the viola da gamba and pardessus de viole - which were considered appropriately feminine - use some movements broadly similar to those used in violin-playing but require very different playing positions. ${ }^{71}$ To begin with, unlike the violin, neither of these instruments involves the chin, meaning that the performer's face and neck can remain relaxed and undisturbed while performing. Given the importance of the male gaze in women's musical performance, being able to observe a performer's face without the instrument interfering is clearly a desirable feature. In fact, the attribute of allowing the performer's upper body to remain freely graceful is shared by all typically "feminine" instruments of this era. The viola da gamba and the pardessus also immobilise the musician - she must sit down, whereas a violinist can sit, stand, or even walk about as they please. The left and right arms furthermore utilise more relaxed or "natural" positions - the left arm is not raised as high as it is for the violin and it does not twist, and the bow arm moves along a horizontal line which sits no higher than the midpoint of the torso. Lap orientation thus requires significantly less contortion and physical effort on the part of the player than does the violin, making it concomitant with the ideals of stillness and sprezzatura.

\footnotetext{
${ }^{68}$ Gillett, Musical Women in England, 78.

${ }^{69}$ Ibid., 81.

${ }^{70}$ Ibid., 80.

71 There appear to be conflicting views on whether the placement of the viola da gamba between the legs was inappropriate for women. Peter Holman has argued it was not inappropriate, while Simon McVeigh's claim the instrument was "manly" suggests he believes it was. There were a significant number of upperclass women players during the eighteenth century, which would seem to indicate the standard position was less shocking than might be expected. See Peter Holman, "Ann Ford Revisited," Eighteenth-Century Music 1, no. 2 (2004): 177-178; Simon McVeigh, Concert Life in London from Mozart to Haydn (Cambridge; New York: Cambridge University Press, 1993), 87. Views of violoncello playing by women are similarly mixed, but in contrast to the gamba, perceptions of the cello as "manly" appear to have been more widespread. George Kennaway, Playing the Cello, 1780-1930 (Farnham: Ashgate Publishing Ltd, 2014) accessed 7 December 2015, http://VUW.eblib.com/patron/FullRecord.aspx?p=1589636. 177-178, 189190.
} 
These key differences between the way in which the violin and "feminine" bowed instruments are played thus signal that it would be rewarding to further explore the role that sight played in eighteenth-century comments on women violinists. There are two points which may account for the absence of detail about specific "offensive" violin movements. Firstly, describing physical movement accurately in written language is particularly difficult, and writers were perhaps further dissuaded by the customarily brief format of reviews and by the lack of enjoyment some derived from these performances. Secondly, the taboo nature of the transgression possibly rendered specific description risqué: writers perhaps did not want to give the thought any more power by painting a clear image in readers' minds. Instead of dismissing the lack of specificity around "inappropriate" movements as evidence that such movements were not important, I suggest that the violin was not only inextricably linked to eighteenth-century European constructs of masculinity, but that the physical movements required to play the instrument also came to be coded as masculine. Essentially, playing the violin required female performers to transgress established physical boundaries surrounding women's musical performance.

In addition to issues surrounding performance and display for women more generally, and the gender associations of the violin as an instrument, playing the violin required female performers to rupture the established physical limits involved in women's musical performance. These limits linked to a broader desire to contain women: if rendered passive, physically and mentally, they posed no threat to the patriarchal status quo. The dynamic and subversive associations of violin-playing reinforced at every turn that it was a danger to men if women and violins were allowed to interact. Despite this, a small but significant group of women did take up the instrument - several to acclaim - and their public performances posed a palpable challenge to the various restrictions placed on women's musical performance. 


\section{Chapter Two}

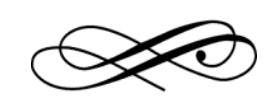

\section{“Much delicacy of finger": Conditions Which Enabled (Some) Women to Play the Violin}

The violinists discussed in this chapter experienced a mixture of conditions which made it possible for them to pursue professional careers. Women violinists often did not have access to the same kinds of employment opportunities as men. For instance, they generally could not work in a court or theatre orchestra (Strinasacchi and several others being exceptions), and few appear to have taught pupils. The primary route taken by women violinists was thus as solo players, in their home town and on international tours. The conditions which enabled female violinists to play despite the barriers that existed have been drawn from a framework used by Sylvia Glickmann. ${ }^{1}$ The conditions for success that are particularly relevant when considering the lives of female violinists are the intertwined factors of "encouragement by an inner circle," access to education, and acceptance by society. ${ }^{2}$ The first section of the chapter focuses on the kinds of support female violinists received from their families and (later) spouses, as well as the educational opportunities they were given access to by family members and teachers. The second explores the kinds of employment opportunities and endorsement women violinists received in the public sphere, while the third looks at ways in which certain women violinists were able to gain greater acceptance and praise from critics and audiences through emulating "masculine" playing styles and dress. The last section centres on institutions where violin-playing by women was fostered, namely convents and the Venetian ospedali, and considers why violin-playing was accepted in these contexts and the varied opportunities that they gave women violinists.

\footnotetext{
${ }^{1}$ Sylvia Glickman, "Introduction," in From Convent to Concert Hall: A Guide to Women Composers, ed. Sylvia Glickman and Martha Furman Schleifer (Westport, CT: Greenwood Press, 2003), 7.

${ }^{2}$ Ibid.
} 


\section{Familial Support and Access to Education}

The kind of musical education a girl might receive was very dependent upon her family and their socio-economic status. The large majority of professional female musicians came from professional musical families (which Nancy Reich has termed the “artist-musician" class) and female violinists were no different. ${ }^{3}$ Within this group it was by and large considered acceptable for women, even married women, to perform professionally. ${ }^{4}$ Of the twenty-four violinists out of a group of sixty-four whose mother's and/or father's occupations are known I have found twenty-two violinists who had one or more parents who were professional musicians, and twelve had parents or close relatives (mostly fathers or uncles) who were violinists. ${ }^{5}$ There are also two cases of mother-daughter violinist pairs: Strinasacchi and her daughter Caroline, and Josepha Schleicher and her two daughters Cordula and Caroline. ${ }^{6}$ Children within professional musical families usually learnt from their parents in an apprentice-like scheme similar to that used in other eighteenth-century professions, and it seems unlikely that these women would have received lessons on the violin if their families did not intend for them to play in public.

Indeed, parents may have chosen to give their daughters violin lessons for financial reasons. Child prodigies were a popular attraction during the late eighteenth and nineteenth centuries, and as the violin was not a standard instrument for girls the additional novelty factor had the potential to result in higher ticket sales. In these cases, parents (usually fathers) often acted as teacher-managers. Rita Steblin, drawing on Freia Hoffmann, suggests that young girls playing instruments like the violin in these contexts

\footnotetext{
${ }^{3}$ Reich, "Women as Musician," 125-126.

${ }^{4}$ Ibid., 126.

${ }^{5}$ Included in the total number but not counted as violinists for whom parents' occupations are known are four royal eighteenth-century women who are known to have played the violin: the sisters Marie-Adélaïde (1732-1800) and Victoire (1733-1799) of France, daughters of Louis XV, and the sisters Wilhelmine of Bayreuth (1709-1758) and Anna Amalia of Prussia (1723-1787), daughters of Frederick I and sisters to Frederick the Great. Julie Anne Sadie, "Musiciennes of the Ancien Régime," in Women Making Music: The Western Art Tradition, 1150-1950, ed. Jane M. Bowers and Judith Tick (Urbana: University of Illinois Press, 1986), 207; Caroline Richter, "Wilhelmine von Bayreuth," Sophie Drinker Institut, accessed 27 January 2015, http://www.sophie-drinker-institut.de/cms/index.php/wilhelmine-von-bayreuth; Anja Herold, "Anna Amalia, Prinzessin von Preußen," ibid., http://www.sophie-drinkerinstitut.de/cms/index.php/anna-amalia-prinzessin-von-preussen.

${ }^{6}$ All three of the Schleicher women also played the clarinet, an instrument that was even more eyebrowraising than the violin, due to its phallic connotations and contact with the mouth. "Schleicher, Josepha," Sophie Drinker Institut, accessed 29 January 2015, http:/ /www.sophie-drinkerinstitut.de/cms/index.php/schleicher-josepha; Freia Hoffmann, "Schleicher, Cordula," ibid., http://www.sophie-drinker-institut.de/cms/index.php/schleicher-cordula; Anja Herold, "Krähmer, Caroline," ibid., accessed 17 September 2014, http:/ / www.sophie-drinkerinstitut.de $/ \mathrm{cmsms} /$ index.php?page $=$ kraehmer-caroline.
} 
contributed to the normalisation of women playing "masculine" instruments in the nineteenth century. ${ }^{7}$ The reason that juvenile violinists may have paved the way for their elder sisters was that, because they were not of marriageable age, the aura of impropriety around the instrument was lessened. Examples of violinists who performed as children include Marie Janitsch, Friederike Klinsing, Klara Sigl, Hannah Lindley Taylor, and Mariane von Berner, as well as the more well-known figures of Louise Gautherot and Strinasacchi.

The only confirmed case of an aristocratic woman who trained as a professional was that of Félicité Lebrun. ${ }^{8}$ She was also the first female violinist to enter the Paris Conservatoire, attending from November 1796 to October 1800. ${ }^{9}$ Lebrun participated in Baillot's violin class (which was otherwise exclusively male), and in 1797 and 1799 won second and first-equal respectively in the Conservatoire's annual competition. Lebrun was not Baillot's only female violin pupil at the Conservatoire at the turn of the century: Adèle Sonneck joined the same class from May 1800 to June $1801 .{ }^{10}$ Frédéric de La Grandville, who has published material from the archives of the Conservatoire, suggests that Lebrun and Sonneck were able to join the men's class due to Baillot's highly respected status at the institution. ${ }^{11}$ By 1815 Kreutzer had followed Baillot's lead, as the seventeen-year-old Elisabeth Blanchet was admitted to his class that December. ${ }^{12}$ These were not insignificant moves on the part of Baillot and Kreutzer, as the Conservatoire otherwise seems to have maintained strict gender segregation in its classes throughout the nineteenth century, setting male and female students different syllabuses and even requiring them to use separate staircases. ${ }^{13}$ The admittance of female violin students appears even more striking given the founding purpose of the Conservatoire as a training centre for (strictly male) military musicians, and the expressly masculine heroism of the violin compositions of Baillot et al. ${ }^{14}$

\footnotetext{
7 Steblin, "The Gender Stereotyping of Musical Instruments," 143.

${ }^{8}$ Freia Hoffmann, "Lebrun, Félicité," Sophie Drinker Institut, accessed 9 March 2015, http://www.sophie-drinker-institut.de/cms/index.php/lebrun-felicite.

${ }^{9}$ Frédéric de La Grandville, Dictionnaire biographique des élèves et aspirants du Conservatoire de musique de Paris (1795-1815) (L'Institut de recherche sur le patrimonie musical en France, 2014) accessed 25 October 2015, http://www.irpmf.cnrs.fr/etudes-et-documents-de-l-irpmf-en/corpus/article/le-conservatoire-demusique-de?lang=fr. 360 .

${ }^{10}$ Ibid., 560.

11 Ibid., 361.

${ }^{12}$ Ibid., 55.

${ }^{13}$ Reich, "Women as Musician," 135.

14 Kawabata, "Virtuoso Codes of Violin Performance," 97 n14.
} 
Outside of Paris, there are perhaps surprisingly extensive examples of female violinists who learnt from famous teachers. Felicita Blangini and Giulia Paravicini received lessons from Gaetano Pugnani, Mariane von Berner from Rode, Marianne Crux from Friedrich Eck, Elizabeth Plunket from Matthew Dubourg, and Catarina Calcagno from Paganini. ${ }^{15}$ Giuseppe Tartini's connection with Lombardini Sirmen is the most well-known example, primarily because he sent a now famous letter to her about practising and violin technique in 1760. Lombardini Sirmen also travelled to Padua on multiple occasions between 1760 and 1766 to take lessons with Tartini in person. ${ }^{16}$ The fact that so many female violinists learnt from renowned teachers seriously undermines the idea that these women were on the fringes of musical life. Rather, through their contact with such teachers, we can see that women violinists engaged with the key eighteenth-century violin schools, and by extension the innovations those schools developed.

If a violinist chose to marry, support from their spouse was also an important factor in whether they continued to perform. An example of an amateur whose husband showed support for her activities was Anne Wathen Leeves, an Englishwoman whose husband William (a clergyman and amateur cellist) wrote doting poems about her violinplaying. These poems clearly show that he found Leeves' choice of instrument to be not only acceptable but even beguiling. ${ }^{17}$ Marrying a fellow professional musician also appears to have significantly increased the likelihood of a violinist continuing to perform publically once she was an adult. A number of violinists performed with their spouses - collaborative performance being an indicator of endorsement - including Lombardini Sirmen, the Schleichers, and Henriette Larrivée Borghese. Some, like

\footnotetext{
${ }^{15}$ H.B., "Blangini, Felicita," Sophie Drinker Institut, accessed 27 January 2015, http://www.sophiedrinker-institut.de/cms/index.php/blangini-felicita; Volker Timmermann, "Paravicini, Giulia," ibid., accessed 9 September 2014, http://www.sophie-drinker-institut.de/cms/index.php?page=paravicinigiulia; H.B., "Berner, Mariane von,” ibid., accessed 13 March 2015, http:/ /www.sophie-drinkerinstitut.de/cms/index.php/berner-mariane-von; Volker Timmermann, "Crux, Marianne," ibid., accessed 9 September 2014, http://www.sophie-drinker-institut.de/cmsms/index.php?page=crux-marianne; "Plunket, Elizabeth," Sophie Drinker Institut, accessed 13 March 2015, http://www.sophie-drinkerinstitut.de/cms/index.php/plunket-elizabeth; François-Joseph Fétis, Nicolo Paganini: With an Analysis of His Compositions and a Sketch of the History of the Violin (London: Schott \& Co., 1860; repr.: Dover Publications, 2013) accessed 5 August 2014, http://books.google.co.nz/books?id=cWzCAgAAQBAJ. ${ }^{16}$ Elsie Arnold and Jane L. Berdes, Maddalena Lombardini Sirmen: Eighteenth-Century Composer, Violinist, and Businesswoman (Lanham, MD: Scarecrow Press, 2002), 30-33.

17 Anna Maria Moon, In Memoriam: The Rev. W. Leeves, Author of the Air of "Auld Robin Gray" (Printed for private circulation, 1887) accessed 7 September 2014, https://archive.org/stream/inmemoriamrevwle00mooniala\#page/n7/mode/2up. 56-57.
} 
Strinasacchi and the Hungarian-Romani violinist Panna Czinka, meanwhile formed family ensembles. ${ }^{18}$

Strinasacchi and Lombardini Sirmen's marriages are of particular interest: both appear to have been, at least in part, economically-driven unions. It is certain that in Lombardini Sirmen's case, as a maestra (ospedali teacher and musical director), she needed to marry a musician in order to leave the Mendicanti. ${ }^{19}$ A letter sent on her behalf by Tartini to the composer Giovanni Naumann in 1766 indicates that she was somewhat desperate to get out. The aim of the letter was to secure employment for her future husband Lodovico Sirmen (also a violinist) and Lombardini Sirmen herself at the Dresden court, thus enabling them to secure permission from the Mendicanti governors to marry and depart Venice. ${ }^{20}$ The implication is that it was only through marrying a professional musician that Lombardini Sirmen could forge a more independent, and probably more exciting, career. ${ }^{21}$ Strinasacchi may have had been similarly bound to the Pietà, though this is unclear, as her exact status there is unknown. In any case, through her marriage to Schlick in 1785, she gained employment at the Gotha court, a relatively secure economic position which she almost certainly would not have been able to take up as an unmarried woman.

\section{Patronage and Employment}

Support for women violinists also came from sources outside of family and teachers, in the form of endorsement from patrons and employers. Examples of women who worked with the court system include Paravicini, who was employed by Josephine de Beauharnais (first wife of Napoleon) as a soloist and violin teacher for her son while in exile in Milan. ${ }^{22}$ Czinka meanwhile was sponsored as a child by the landowner Ján Lányi to have lessons with a local violin teacher, and Strinasacchi received patronage from both Prince August of Gotha and Anna Amalia of Weimar. ${ }^{23}$ Others, such as Crux

\footnotetext{
18 Anna G. Piotrowska, Gypsy Music in European Culture: From the Late Eighteenth to the Early Twentieth Centuries, trans. Guy R. Torr (Boston, New England: Northeastern University Press, 2013), 21.

${ }_{19}$ Arnold and Berdes, Maddalena Lombardini Sirmen, 35, 39; Berdes, Women Musicians of Venice, 141-142.

20 The letter was unsuccessful but the couple were later given permission and set off to tour Europe. Arnold and Berdes, Maddalena Lombardini Sirmen, 39-40, 46.

${ }^{21}$ Lombardini Sirmen frequently toured without her husband. Ibid., 57-58, 96.

22 Timmermann, "Paravicini, Giulia".

23 Piotrowska, Gypsy Music in European Culture, 21; Timmermann, "Strinasacchi, Regina".
} 
and Caroline Bayer (or Baier) are known to have performed for royalty. ${ }^{24}$ Such diverse examples of patronal support of female violinists are of significance: as is well known, a key purpose of patronage was to communicate that patron's prestige and wealth. ${ }^{25}$ This being the case, it is not unreasonable to assume that these patrons of female violinists felt the musicians they supported to be appropriate reflections of their prestige. Such endorsements can be seen as important steps towards the legitimisation of women violinists in their own day, and again shows that these women were very much a part of the eighteenth-century musical economy.

Performance opportunities for female violinists outside of the courts were sometimes available in private salons. Strinasacchi is known to have performed in a private concert hosted by Prince Kaunitz in Vienna in April 1784, and it is possible that other of the more well-known violinists also participated in this practice while touring. ${ }^{26}$ At her home in Paris, Madame Blangini (the mother of the violinist Felicita) held salons where the Italian violinists Rosalie Tognini and Luisa Gerbini performed in April 1810 and January $1811 .^{27}$ As Gerbini and Felicita Blangini are both known to have been pupils of Pugnani in Turin, it seems probable that they had known each other before the Blanginis settled in Paris. Felicita is also known to have been the violist of the first documented all-female string quartet, formed around 1800, which consisted of Mme. Ladurner (first violin), Clarisse Larcher (second), and Thérèse-Rosalie Pain (violoncello). ${ }^{28}$ Blangini also wrote and dedicated a string trio to Larcher. ${ }^{29}$ As well as showing that women violinists participated in salon culture, this suggests that being in a position to interact with other women violinists professionally and socially could be creatively stimulating in a variety of ways, resulting in collaborations and commissions.

Female violinists were not restricted to performing in "private" settings - in fact there are far more recorded instances of public performance. The concert series that

\footnotetext{
24 "Crux, Marianne”; "Bayer, Caroline," Sophie Drinker Institut, accessed 10 July 2015, http://www.sophie-drinker-institut.de/cms/index.php/bayer-caroline.

${ }^{25}$ William Weber, “The Contemporaneity of Eighteenth-Century Musical Taste," The Musical Quarterly 70, no. 2 (1984): 180.

${ }^{26}$ Mary Sue Morrow, Concert Life in Haydn's Vienna: Aspects of a Developing and Social Institution (Stuyvesant, NY: Pendragon Press, 1989), 377.

${ }^{27}$ Les Tablettes de Polymnie: Journal consacré à tout ce qui intéresse l'art musical (Paris, 1810-1811; repr. Geneva: Minkoff Reprints, 1971) accessed 8 August 2015, http:/ / babel.hathitrust.org/cgi/pt?id=osu.32435056265077; view=1up;seq=254. 14; 232-234; 261.

${ }^{28}$ Freia Hoffmann, “Ladurner, Vorname unbekannt," Sophie Drinker Institut, accessed 27 January 2015, http://www.sophie-drinker-institut.de/cms/index.php/ladurner.

${ }^{29}$ Mlle. T Blangini, Trio à Violon Principal, Second Violon et Basse, composé et dédié à Madame Larcher (Paris: Benoît Pollet, c. 1800).
} 
booked the most female violinists during the eighteenth century was probably the Concert Spirituel in Paris, where Lombardini Sirmen, Gautherot, and Paravicini all performed on multiple occasions. ${ }^{30}$ In London, Wilhelm Cramer's "Professional Concert" series and Johann Peter Salomon's rival series also engaged Gautherot between 1789 and 1791, while Madame Guilberg appeared at Salomon's in 1795. ${ }^{31}$ Vienna saw a comparatively high number of female violinists perform in its theatres (ten between the 1770s and 1810s) including international artists like Strinasacchi and Gerbini, and local violinists such as Josepha Ringbauer. ${ }^{32}$ Benefit concerts were also a major source of income for professional violinists, with many performing in London and Paris as well as cities throughout German- and Italian-speaking states. Though securing patronage and "private" concert opportunities require no less skill, the myriad appearances of female violinists on public stages alerts us to the fact that they were businesswomen. In order to put on concerts, touring virtuosi had to build relationships with local patrons and musicians, organise venues, ticket sales, and exercise numerous other skills, rendering them entrepreneurs. ${ }^{33}$ Though spouses or fathers may sometimes have acted in a managerial capacity, it should not be assumed that this role was always carried out by a male relative, as Lombardini Sirmen's highly independent status shows. $^{34}$

Female violinists did not only perform as soloists but as orchestral musicians, a striking fact considering the huge resistance that women musicians faced throughout Europe when trying to enter orchestras in the late nineteenth century. Women had been playing in ensembles within the ospedali and in convents since the seventeenth century, but Strinasacchi is thought to be one of the earliest female orchestral violinists to perform outside a cloistered environment. ${ }^{35}$ According to Louis Spohr, she was a member of the Gotha court orchestra by 1805, though she may well have performed with the ensemble from a much earlier date. ${ }^{36}$ Other pioneering orchestral violinists

\footnotetext{
${ }^{30}$ Arnold and Berdes, Maddalena Lombardini Sirmen, 51, 99; Volker Timmermann, "Gautherot, Louise," Sophie Drinker Institut, accessed 30 January 2015, http://www.sophie-drinkerinstitut.de/cms/index.php/gautherot-louise; "Paravicini, Giulia".

31 Thomas B. Milligan, The Concerto and London's Musical Culture in the Late Eighteenth Century (Ann Arbor, MI: UMI Research Press, 1983), 7, 138-139.

32 Morrow, Concert Life in Haydn's Vienna, 6, 8, 170, 270.

33 William Weber, “The Musician as Entrepreneur and Opportunist, 1700-1914," in The Musician as Entrepreneur, 1700-1914: Managers, Charlatans, and Idealists, ed. William Weber (Bloomington, IN: Indiana University Press, 2004), 10-12.

34 See Timmermann, "Plunket, Elizabeth"; Arnold and Berdes, Maddalena Lombardini Sirmen, 2, 57-58, 101.

35 Timmermann, "Strinasacchi, Regina".

${ }^{36}$ Louis Spohr, Louis Spohr's Autobiography (London: Longman, Green, Longman, Roberts, \& Green, 1865), 88-89.
} 
were the Schleicher sisters. Cordula played at an unnamed music hall in 1806 and in the Orchester der Züricher Allgemeinen Musikgesellschaft from 1812-1814. ${ }^{37}$ Caroline meanwhile held a position in the Kapelle of the Prince of Hohenzollern-Sigmaringen, was employed as a first violinist and sometimes concertmaster of an orchestra in the spa town of Baden, Switzerland, in 1809, and took up a position in the Karlsruher Orchester in Karlsruhe, Germany, around $1819 .{ }^{38}$ As early as 1798 , Swiss violinist Marie Janitsch led the orchestra of an operatic society in Hannover and around 1804 held the post of Konzertmeisterin in Bern. ${ }^{39}$

It was even more unusual for a female violinist to play in an orchestra than as a soloist because, according to Green, participating as part of the section in a maledominated orchestra causes a greater interruption to a performer's femininity than solo playing, where the violinist is separate. ${ }^{40}$ The audience's ability to interpret her performance in an orchestra as display is hindered because as she carries out the same gestures as the men around her she becomes a member of the collective. ${ }^{41}$ Particularly as a member of a theatre orchestra, a female orchestral violinist was also decidedly in the public sphere. The existence of no less than four women violinists in otherwise male orchestras almost two centuries before this was to become standard is thus astounding: they were truly pioneers.

\section{Emulating Men}

Female violinists sometimes also received endorsement in written criticism. Concurrent with the kinds of negative reviews discussed in Chapter One, there was a substantial body of positive accounts that appeared in published sources. These included the Allgemeine Musikalische Zeitung, Mercure de France, World and Fashionable

\footnotetext{
${ }^{37}$ Hoffmann, "Schleicher, Cordula".

${ }^{38}$ Caroline also performed clarinet solos with the Baden orchestra and was, according to Hoffmann, the first woman to establish a significant career on that instrument in the early nineteenth century. Her choice of two unusual instruments likely made her doubly intriguing to audiences. Anja Herold, "Krähmer, Caroline," ibid., accessed 17 September 2014, http:/ / www.sophie-drinkerinstitut.de/cmsms/index.php?page=kraehmer-caroline; Freia Hoffmann, "Die Klavierlehrerin: Caroline Krähmer und ein literarisches Stereotyp," ed. Cordula Heymann-Wentzel and Johannes Laas, Musik und Biographie: Festschrift für Rainer Cadenbach (Würzburg: Königshausen \& Neumann, 2004), accessed 13 July 2015, http://books.google.co.nz/books?id=DG7t3TgLKyAC, 155-156.

${ }^{39}$ Anja Herold and Jannis Wichmann, “Janitsch, Marie," Sophie Drinker Institut, accessed 27 January 2015, http://www.sophie-drinker-institut.de/cms/index.php/janitsch-marie.

${ }^{40}$ Green, Music, Gender, Education, 68.

${ }^{41}$ Ibid., 68-69.
} 
Advertiser, and Morning Chronicle among many others. ${ }^{42}$ Of specific writers who penned favourable accounts, Johann Friedrich Reichardt and Charles Burney are only two of the most eminent examples. ${ }^{43}$ While it is not my intention to provide a comprehensive reception study, there are certain themes which appear in accounts of women violinists, making a brief examination of critical responses useful. It becomes clear, for instance, that the ways in which they played naturally affected how they were received: specifically, the manlier a violinist's playing style, the better many commentators considered a woman violinist to be as a musician. Reichardt, for instance, praised Paravicini "because her playing is so masculine-powerful." 44 A Viennese review from 1807 regarding Gerbini, meanwhile, stated that "she can be counted among the strongest violinists [Violinisten] (men included) and has the power in her bow and certainty and strength even in the highest notes, and a precision of execution that make her completely worthy of general approbation. ${ }^{~} 45$ Masculinity in this context is interwoven with the concept of physical and aural strength, at odds with the perception of women as the weaker sex. By the same token, a violinist might be criticised for not being manly enough, as was Henriette Larrivée in a review from 1791 in which the writer stated that they had "no objection to the efforts of the sex on the Violin" but "that it requires the more muscular tone of a man, than the delicacy of female nerves to accomplish the instrument."

For commentators who were against female violinists, the categories "woman" and "violinist" were mutually exclusive. For many who gave favourable accounts though, "violinist" as a concept was still perceived as incomplete without some aspect of "man." By describing their playing as manly, commentators essentially bestowed the title of honorary man on violinists they admired as a way of rationalising their abilities. Those who were perceived as having an insufficiently masculine style were subsequently also inadequate violinists. So while positive reviews which cast female violinists as masculine mark progress in the acceptance of female violinist, they still display the difficulty eighteenth-century listener/viewers had in attempting to reconcile the ideas that someone could be both a skilled violinist and a woman.

\footnotetext{
42 Timmermann, "Paravicini, Giulia"; "Gautherot, Louise".

43 See Head, Sovereign Feminine, 17; Charles Burney, The Present State of Music in France and Italy: Or, the Journal of a Tour through Those Countries, Undertaken to Collect Materials for a General History of Music (London: T. Becket and Co, 1771), 183, 251.

${ }^{44}$ Kawabata, "Virtuoso Codes of Violin Performance," 106.

${ }^{45}$ Morrow, Concert Life in Haydn's Vienna, 217-218.

${ }^{46}$ Quoted in McVeigh, Concert Life in London, 87.
} 
Emulating men while playing the violin was not just connected to playing style, but the clothes worn by women violinists. In her autobiography, Getrud Mara (the famous opera singer who played the violin as a young girl) recounted that she "would dress in a riding habit [Amazonen-Habit - a floor-length riding coat], because one found that this attire was the most appropriate for violin-playing." ${ }^{47}$ Women's riding habits were at this time closely modelled on men's styles, and negative reactions show such outfits were considered by conservative commentators to transgress gender boundaries. ${ }^{48}$ Mara's wearing of a riding habit (the German term for which implies both masculine gender and its connection to the Amazon figure) thus carries links to her act of violin-playing, implying that the appropriateness of such an outfit lay more in its gender-muddling properties - which echoed the effect of the violin itself - than merely the practical benefits that riding clothes might afford violin-playing, in terms of ease of movement. ${ }^{49}$

This idea is supported by Junker, who said that women who wore riding habits while playing the violin more closely resembled men. ${ }^{50}$ Intriguingly, he appears to suggest that the "feeling of indecency" is weakened by the wearing of masculine clothing, indicating that impropriety is paradoxically increased when a woman plays the violin while wearing more feminine attire. That "indecency" might be lessened by a woman violinist's appearance being perceived as more masculine - whether by clothing or other means - is further supported by a response to Gerbini from 1803. In a review from the Zeitung für die elegante $W$ elt, the author remarked that "her more masculine than feminine attitude and figure prevented too glaring a contrast [between violin and performer]...,

\footnotetext{
${ }^{47}$ My translation: "Ich wurde in einen Amazonen-Habit [lose fallende bodenlange Kleidung für Reiterinnen] gekleidet, weil man fand, dass dieser Anzug am besten zur Violine passe.” Quoted in Freia Hoffmann, "Schmeling, Gertrud," Sophie Drinker Institut, accessed 16 January 2015, http://www.sophie-drinker-institut.de/cms/index.php/schmeling-gertrud.

${ }^{48}$ Dror Wahrman, The Making of the Modern Self: Identity and Culture in Eighteenth-Century England (New Haven: Yale University Press, 2004), 59.

${ }^{49}$ See ibid., 7-8. For further discussion on riding habits, gender roles, and the Amazon figure see Cally Blackman, "Walking Amazons: The Development of the Riding Habit in England during the Eighteenth Century," Costume Costume 35, no. 1 (2001): 47-58.

${ }^{50}$ My translation: "Man 'sehe das nemliche [Geige spielende] Frauenzimmer, nun im Amazonenhabit, also in einer Kleidung spielen, in welcher sie sich dem Manne, mehr annähert, und jenes Gefühl des Unschicklichen wird um vieles geschwächt."' Quoted in Hoffmann, "Schmeling, Gertrud".

${ }^{51}$ My translation: "Ihre mehr männliche als weibliche Haltung und Gestalt verhinderte dabei einen zu grellen Kontrast." "Signora Luigia Gerbini," ed. Karl Spazier, Zeitung für die elegante Welt (Berlin: Janke, 29 October 1803), accessed 1 February 2016, http://www.mdz-nbn-

resolving.de/urn/resolver.pl?urn=urn:nbn:de:bvb:12-bsb10532399-9. Quoted in Volker Timmermann, “Gerbini, Luigia," Sophie Drinker Institut, accessed 9 September 2014, http://www.sophie-drinkerinstitut.de/cmsms/index.php?page=gerbini-luigia.
} 


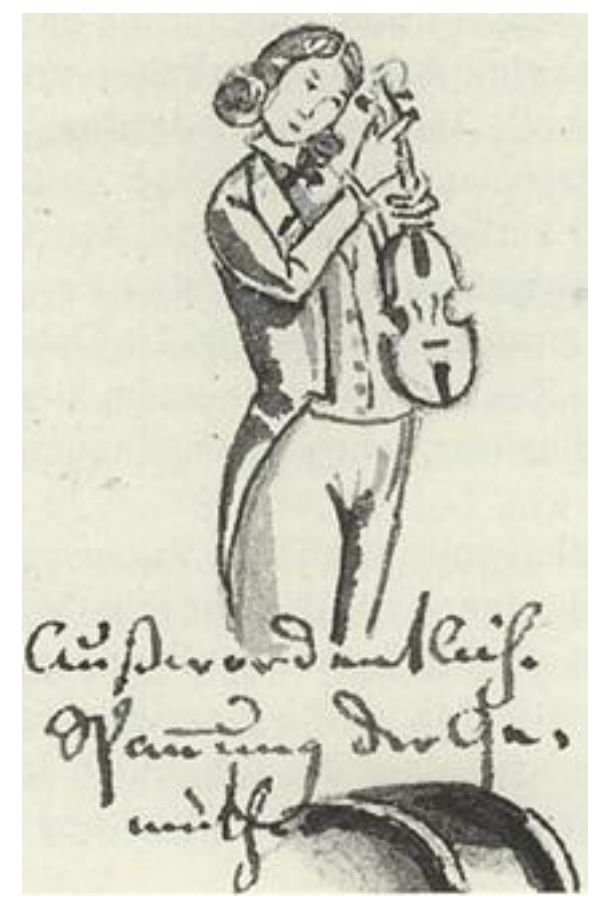

Figure 2. Josepha Marti-Zbinden as a young woman (early nineteenth century). ${ }^{52}$

Countering accusations of indecency appears to have motivated other female violinists go a step further and don actual men's clothing, rather than merely masculineinspired items. The first example was Czinka, who wore the livery of her patron's household when performing. ${ }^{53}$ A later example is Josepha Marti-Zbinden, a Swiss violinist who performed with her father's dance orchestra in the early nineteenth century (fig. 2) ${ }^{54}$ Hoffmann suggests that Marti-Zbinden would not have been able to perform with the all-male ensemble if she had not also dressed in men's clothing. ${ }^{55}$ The transgressive act of cross-dressing thus appears to have been less problematic than, firstly, playing the violin, and secondly, highlighting that she was the only woman in the band through the act of wearing women's clothing. It is pertinent to note that both these violinists were from lower-class backgrounds. This suggests that their crossdressing was a means through which they attempted to assume power in a maledominated environment. ${ }^{56}$ As well as employing a "masculine" style of playing, then, performing in men's or masculine-inspired clothing could paradoxically reduce the

\footnotetext{
${ }^{52}$ François de Capitani and Gerhard Aeschbacher, Musike in Bern: Musik, Musiker, Musikerinnen und Publikum in der Stadt Bern vom Mittelalter bis heute (Bern: Historischer Vereins des Kantons Bern, 1993), 182. Reproduced from Freia Hoffmann, "Marti-Zbinden, Josepha," Sophie Drinker Institut, accessed 9 March 2015, http://www.sophie-drinker-institut.de/cms/index.php/marti-zbinden-josepha.

53 Piotrowska, Gypsy Music in European Culture, 21.

${ }^{54}$ Hoffmann, "Marti-Zbinden, Josepha".

${ }^{55}$ Ibid.

56 Vern L. Bullough and Bonnie Bullough, Cross Dressing, Sex, and Gender (Philadelphia: University of Pennsylvania Press, 1993), 68.
} 
impropriety perceived in women's violin-playing, in turn enabling these women to perform as professionals.

While the majority of favourable accounts emphasise the performer's successful embodiment of violinistic masculinity, it is important to note that there are accounts that suggest an alternative conception of violin-playing that explicitly involved femininity. This is apparent in an English review of Madame Guilberg from 1795, which stated that

her youth and beauty, added to a delicate, though rather feeble tone, a brilliant shake, and great neatness of execution, interested her hearers, who expressed their approbation with repeated plaudits. The Adagio in particular (composed by Viotti, much to his honour) she played in a chaste and charming style. ${ }^{57}$

Here we see a reference to the performer's physical attractiveness, typical for accounts of women's performance. It also, however, invokes typically feminine traits such as delicacy, charm, chastity, and accuracy, characteristics which carried great value in other kinds of women's performance. ${ }^{58}$ Another account, this from the private writings of Susan Burney, concerns Gautherot and also concentrates on the concept of accuracy by referring to the violinist's "rapid execution, \& so much precision." 59 Through praising Gautherot's precision (she has little else favourable to say), Burney places Gautherot's playing within the realm of brilliant but "empty" virtuosity, a concept linked to the perception of virtuosic women's keyboard-playing as mechanical. ${ }^{60}$ Fast passagework was seen as falsely impressive, ultimately lacking in genuine feeling - thus machine-like - which aligned such musical effects with a broader view of women and their activities as superficial and sometimes deceptive. ${ }^{61}$ Mechanical metaphors such as the comparison of keyboard-playing women with automata and the use of descriptive words like "rattling" can be seen works such as Maria Edgeworth's treatise, Practical Education. ${ }^{62}$ The associations of fast passagework with a particular kind of display-focused

\footnotetext{
${ }^{57}$ London, Morning Chronicle, 24 February 1795. Quoted in Milligan, The Concerto and London's Musical Culture, 136.

58 Green, Music, Gender, Education, 101.

${ }^{59}$ Ian Woodfield, Salomon and the Burneys: Private Patronage and a Public Career, vol. no. 12 (Burlington: Ashgate, 2003), 41-43.

${ }^{60}$ Ibid., 42.

61 This evokes Rousseau's statement regarding women writers as able to "acquire science, erudition, talents, and everything that is acquired by virtue of work" but incapable of producing work that was anything but "cold and pretty." Rousseau, Letter to D'Alembert and Writings for the Theater, 327.

${ }^{62}$ Hohl Trillini, The Gaze of the Listener, 67-68. See also Gillen D'Arcy Wood, Romanticism and Music Culture in Britain, 1770-1840: Virtue and Virtuosity (Cambridge; New York: Cambridge University Press, 2010), 65.
} 
femininity show that, while descriptions of women's violin performances as masculine (whether positive or negative) predominated in the eighteenth century, the idea that violin-playing could be seen as an activity that encompassed contemporaneous understandings of femininity was also explored by some writers.

\section{Convents and the Venetian ospedali}

The convents of Catholic Europe and the ospedali were the only contexts where concentrated and relatively consistent support existed for female violinists to learn, collaborate, and perform regularly as soloists and in ensembles. Convents that are known to have had resident violinists and all-female ensembles existed in Italy, Spain, France, Poland, and in Vienna and Brno (in the modern day Czech Republic). ${ }^{63}$ Though the four ospedali - the Pietà, Derelitti, Mendicanti, and Incurabili - were sometimes mistaken for convents by tourists, they were in fact charitable institutions originally established in the sixteenth century to house and educate poor, orphaned, and invalided children. Importantly, they provided a high quality of musical education for female wards, known collectively as the figlie del coro. ${ }^{64}$ By the eighteenth century the institutions were so famous for the musical activities that girls from middle class or even wealthy families were quite frequently admitted. ${ }^{65}$ The ospedali and in some cases convents thus provided musical education to a much wider range of girls than those who were to became nuns or permanent residents.

There are a number of factors that enabled and normalised violin performance by women within these contexts. Firstly, both convents and the ospedali were religious institutions, the spiritual purpose of their music-making rendering it for the most part acceptable. ${ }^{66}$ Instrumental music was furthermore a relatively common (though

\footnotetext{
${ }^{63}$ Burney, The Present State of Music in France and Italy, 358-62; Colleen Baade, "Two Centuries of Nun Musicians in Spain's Imperial City," TRANS: Revista transcultural de música/Transcultural Music Review 15(2011): 10; Horace Walpole, “Letter No. 109 to George Montagu, Esq., 17 September 1769," in Letters of Horace Walpole (London: T. Fisher Unwin, 1890); Elizabeth Rapley, A Social History of the Cloister: Daily Life in the Teaching Monasteries of the Old Regime (Montreal: McGill-Queen's University Press, 2001); Magdalena Walter-Mazur, "The Musical Practice of the Sandomierz Benedictine Nuns During the Eighteenth Century," Interdisciplinary Studies in Musicology 11(2012): 187-198; Janet K. Page, Convent Music and Politics in Eighteenth-Century Vienna (Cambridge: Cambridge University Press, 2014); Ken Shifrin, "The Women's Orchestra of Old Brno," Early Music America 11, no. 2 (2005): 26-28, 46.

${ }^{64}$ This was however declining in the late eighteenth century. Berdes, Women Musicians of Venice, 113.

65 Ibid., 116-121.

66 Tonelli, "Women and Music in the Venetian Ospedali," 26-27.
} 
contentious) feature of religious services throughout Europe, particularly in Italy. ${ }^{67}$ Secondly, violins comprised the core of instrumental ensembles, so any ensemble in such institutions would have been improbable without them. The fact that the ensembles were comprised only of women rendered them more acceptable to the governing authorities and outsiders. ${ }^{68}$ Green argues that the all-female nature of the ospedali cori, coupled with the discourse of religiosity in fact provided "a temporary solution to the interruptive potential of femininity that is delineated by female instrumental performance." ${ }^{99}$ Fourthly, public performances by the cori were integral to the survival of the ospedali. Steblin has suggested that the figlie were allowed to play "masculine" instruments because the novelty drew larger audiences and thus more donations. ${ }^{70}$ Finally, both convents and the ospedali were ultimately under the jurisdiction of male authorities: church heads such as the local bishop, and the ospedali's governing boards, made up of aristocratic or wealthy Venetian men (though at the Derelitti widows could succeed their husbands and sit on the board). ${ }^{71}$ This indicated that, despite the fostering of women's musical activities that went on in these contexts, their institutions were still under often strict patriarchal control.

Nuns were usually physically separated (cloistered) from the outside world, meaning that when they were performing, musicians had to be obscured from the audiences' view. The ospedali took a similar approach. Separation in performance was achieved by placing the musicians in an inner chapel, on balconies above the audience, and by using grilles, significantly reducing display (see fig. 4). ${ }^{72}$ The decision to mask these women musicians' performances shows that the ecclesiastical authorities and governing boards were well aware of the effect display had and the power it could bestow upon the performers. Masking display supposedly protected the modesty and piety of nuns and the figlie, but in reality this highly intentional disembodiment of women's musical sound imposed by external forces can be viewed as a method for controlling female agency and sexuality. ${ }^{73}$ The numerous conflicts that occurred between nuns and their superiors throughout the sixteenth through eighteenth centuries about what nuns could and could

\footnotetext{
${ }^{67}$ Spitzer and Zaslaw, The Birth of the Orchestra, 160-161, 215.

${ }^{68}$ Male wards did not receive musical training. Berdes, Women Musicians of Venice, 81.

${ }^{69}$ Green, Music, Gender, Education, 65.

70 Steblin, "The Gender Stereotyping of Musical Instruments," 142.

${ }^{71}$ Berdes, Women Musicians of Venice, 67.

72 Barbara Garvey Jackson, "Musical Women of the Seventeenth and Eighteenth Centuries," in Women and Music: A History, ed. Karin Pendle (Bloomington, IN: Indiana University Press, 2001), 98; Berdes and Whittemore, $A$ Guide to Ospedali Research, 81.

73 Indeed, this was a key aim of cloistering more broadly. Mario Rosa, "The Nun," in Baroque Personae, ed. Rosario Villari (Chicago: University of Chicago Press, 1995), 198.
} 
not do musically are a testament to the perceived power that music and the concept of musical freedom carried. ${ }^{74}$

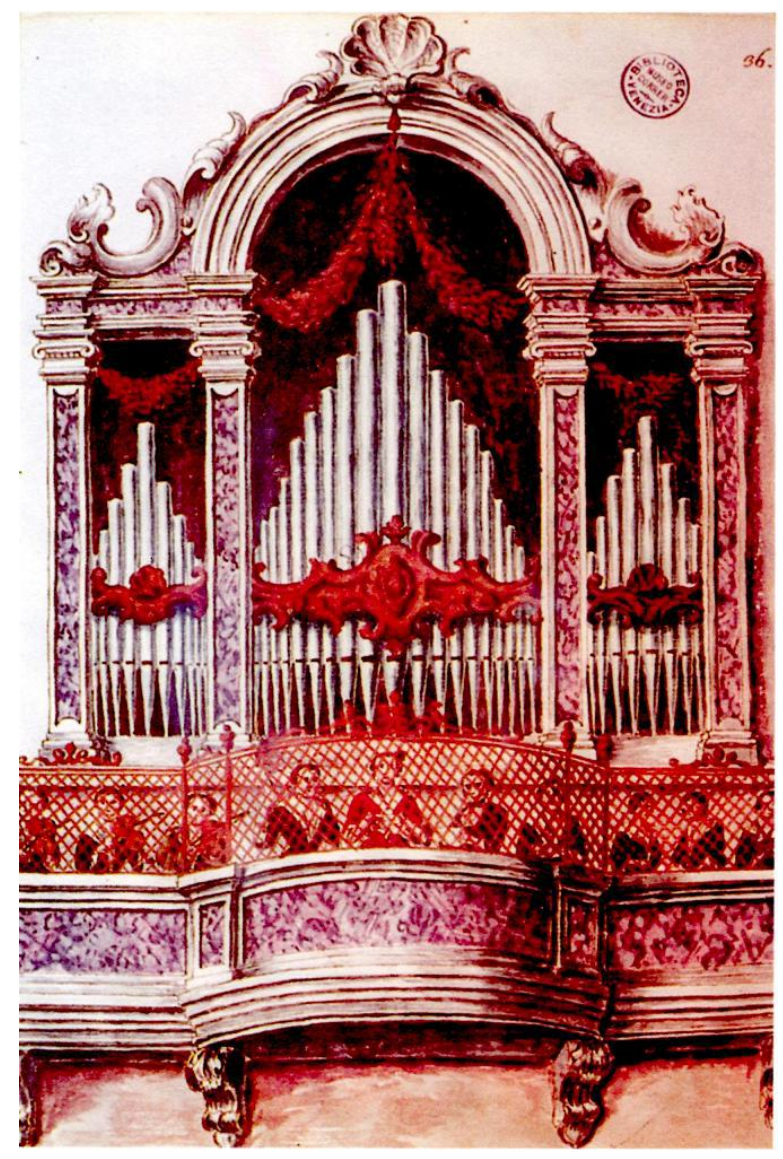

Figure 3. A performance at the Pietà during the eighteenth century - violinists on left. ${ }^{75}$

Removing the visible body from musical performance does not, however, remove the body altogether. In the pre-recording age, music was of course inseparable from body as it could not be produced without it. The imagined body thus still played a powerful role in this unseen music. While obscuring the musicians from view did have the effect of maintaining their holiness in the minds of some, for others the imagined musical body was perhaps even more tantalising than those they could see in the opera house. ${ }^{76}$ In these instances, the absence of sight, the lure of the forbidden and unknown was ironically more arousing for some audience members. This is clear from the sometimes sensual descriptions of ospedali performances. Rousseau's account of his

\footnotetext{
74 See Craig A. Monson, Divas in the Convent: Nuns, Music, and Defiance in Seventeenth-Century Italy (Chicago: University of Chicago Press, 2012).

${ }^{75}$ Giovanni Grevenbroch, Orfane filarmoniche, 1754, in Gli abiti de Veneziani di quasi ogni età con diligenza raccolti, e dipinti nel secolo XVII, vol. 4, Museo Correr, Venice. Reproduced from Denis Stevens, "Musicians in 18th-Century Venice," Early Music 20, no. 3 (1992): 402.

${ }^{76}$ Spitzer and Zaslaw, The Birth of the Orchestra, 176.
} 
experience at the Mendicanti from his Confessions describes the coro's concealed performances as "voluptuous" (voluptueux) and "delicious" (délicieux). ${ }^{77}$ He expresses an almost obsessive desire to see the women, conveying agitation at not being able to observe them clearly and noting that he "felt a shuddering of love that I had never experienced" just before meeting the performers. ${ }^{78}$ The fleshly descriptions Rousseau used convey a physical response to the music, the eroticism of which was greatly heightened for him by the fact that the sounds' source was invisible.

Though the cloistered figlie and convent musicians often spent their whole lives within their institutions, there is a strong case for considering their time working there as professional careers. This is particularly the case with the figlie: each musician received a portion of the profits from their performances, as those who trained younger girls did from their teaching, so the figlie earned personal income. ${ }^{79}$ Lombardini Sirmen, for instance, had accrued the large sum of 3,000 ducats by the time she left the Mendicanti in $1767 .^{80}$ Furthermore, it was through income from the women's performances that the ospedali were sustained financially, thus the quality of their performance was of great importance. ${ }^{81}$ The names of over sixty violinists are recorded in the ospedali archives, of which Chiara della Pietà was one of the most renowned at mid-century. ${ }^{82}$ Chiara not only had numerous works dedicated to her by composers like Vivaldi and Antonio Martinelli, but was said by Charles de Brosses to be among the best, i.e. professional male, violinists in Italy, further strengthening the claim of the women to professional status. ${ }^{83}$

The ospedali can also be seen as a training ground not only for orphaned girls, but for those wishing to go on to professional careers in the secular world. Berdes has already suggested this was the case for numerous opera singers who went through the institutions. They also appear to have served this role for some violinists: a number, including Strinasacchi, came from families of professional musicians and did not remain

\footnotetext{
${ }^{77}$ Jean-Jacques Rousseau, The Confessions and Correspondence, Including the Letters to Malesherbes, ed. Christopher Kelly, Roger D. Masters, and Peter G. Stillman (London: University Press of New England, 1995), 264; Les confessions de J. J. Rousseau (Paris: Charpentier, 1841), 325.

78 The Confessions, 265.

${ }^{79}$ Berdes, Women Musicians of Venice, 165-166.

80 Arnold and Berdes, Maddalena Lombardini Sirmen, 40.

81 Tonelli, "Women and Music in the Venetian Ospedali," 27-28.

82 Berdes and Whittemore, A Guide to Ospedali Research, 432-511.

${ }^{83}$ Charles de Brosses, Selections from the Letters of de Brosses, trans. Ronald Sutherland Gower (London: K. Paul, Trench, Trübner, \& Co., 1897), 51.
} 
at the ospedali. ${ }^{84}$ Besides the wards there were two other groups within the figlie: figlie d'educazione, or scholarship students; and figlie di spese, fee-paying students. ${ }^{85}$ Figlie di spese could be boarders but also local Venetian day students, essentially private pupils taught by the maestra di coro, while daughters of professional musicians could come from further afield. ${ }^{86}$ Lombardini Sirmen, Leila Achiapati, Maria Canciana, Teresa Maruzzi, and Antonia Perona are some of the violinists from these categories who appear in the ospedali archives, indicating that the ospedali enabled something of a culture of violin-playing among girls not just from orphan backgrounds to develop in Venice and surrounding areas. ${ }^{87}$

In the convent system, girls with musical talent were sometimes admitted with portions of their convent dowries waived. ${ }^{88}$ Women with waived dowries who were unable to fulfil their musical duties, either through failing to meet expectations or through falling ill, were in many cases required to pay a further portion of their dowry in order to stay on at their convent. ${ }^{89}$ There are other examples of women who were musicians but chose to pay full dowries so as to not be contractually obliged to perform. ${ }^{90}$ These cases all indicate that convent musicians did indeed "work" in a sense similar to their secular counterparts employed at court, and may have held an equivalent level of social status - as skilled servants. Colleen Baade has even found evidence that some nuns received financial compensation for their performances. ${ }^{91}$ This culture of waiving entry dowries also shows that women and girls did not always enter convents for strictly religious reasons, and that music in convent life was by no means casual affair but an undertaking that required trained musicians. It may have been work in the service of God, but it was nevertheless work.

Convents, as providers of education to thousands of European girls, may also have enabled access to violin lessons for girls who were not nuns. Historian Elizabeth Rapley has noted that accounts of the Ursuline convent school at Montbard show violin lessons, along with other artistic activities, were provided for the students in the 1790 s

\footnotetext{
${ }^{84}$ Berdes, Women Musicians of Venice, 118.

85 Ibid., 116-121.

86 Ibid., 117, 118, 120-121.

87 Berdes and Whittemore, A Guide to Ospedali Research, 432, 446, 480, 488.

88 Page, Convent Music and Politics, 93; Baade, "Two Centuries of Nun Musicians," 19.

89 “Two Centuries of Nun Musicians," 15.

${ }^{90}$ Ibid., 16-18.

91 "'Hired' Nun Musicians in Early Modern Castile."
} 
due to requests from the girls' families. ${ }^{92}$ Girls might have the opportunity to learn the violin from nuns or from external male teachers. This shows that in some cases it was not only nuns playing the instrument in France, but their upper-class female pupils. In other words, a wider group of aristocratic or wealthy women may have had opportunities to learn the instrument in France, and this may well have been the case in other European cities. The only western-European country that did not have convents (and thus convent schools) in the eighteenth century was Britain. It is possible that the practice of playing the violin in convents, convent schools, and the ospedali to a certain extent normalised the act in Continental communities adjacent to convents. As convents had not existed in Britain since the sixteenth century, a woman playing the violin may have seemed much more out of the ordinary there, and contributed towards the greater level of negativity towards female violinists among Britons.

Female violinists outside of convent or ospedali communities received encouragement and educational support from family members, spouses, and teachers. Mentors and teachers could also help their female pupils secure employment. In the public sphere, support came in the form of employment and patronage, economic support that carried with it a sense of professional validation. Colleagues who performed with female violinists also aided their participation in the highly collaborative nature of putting on concerts in the late eighteenth century, though clearly some fellow musicians did not approve of their instrument choice. Although economic support from audiences may not necessarily have translated into endorsement, those who chose to pay to see female violinists perform nevertheless enabled these women to continue performing. In order to be taken seriously as a musician, one method available to women violinists was to emulate a "masculine" playing style, equated with physical and aural strength. In some cases, dressing as man or in masculine-inspired clothing also paradoxically allowed women violinists to perform when their gender and outward display of that gender might otherwise have precluded this.

Within the ospedali and sometimes in convent communities, women violinists also effectively worked as professional musicians and, unlike their non-cloistered counterparts, were part of a community of musical women in which they frequently performed in ensembles. We can also imagine that these contexts where many women

92 Rapley, A Social History of the Cloister, 242, 343 n51. 
violinists worked together were places in which they found emotional support through interaction with musicians similar to themselves. At the very least these contexts provided female role models for younger violinists. Though reception of nun and ospedali musicians by the outside world was increasingly ambivalent, during the eighteenth century the music-making of the ospedali in particular was accepted by the wider community. These many examples of different forms of supportive relationships between female violinists and those around them show that they did not exist in isolation, and in fact received a much higher level of endorsement than one might think, given the apparently subversive nature of their performances in an eighteenth-century context. 
This page is left intentionally blank. 


\section{Chapter Three}

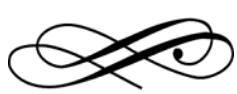

\section{Gender and Gesture in Late Eighteenth-Century Women's Violin Performance: Regina Strinasacchi's Violin Concerto in B flat major}

The perception that a violin-playing woman was a subversive sight permeates late eighteenth-century accounts. Commentators saw female violinists' physical movements as intriguing and sometimes distasteful (only a minority were so nonplussed as to make no explicit mention of the performer's body). But what movements might commentators have been reacting to, and what kind of music might produce such movements? Given the importance ascribed to gender and gesture in women's violin performance, this chapter takes as its focus a piece composed by a female violinist - Strinasacchi's Violin Concerto in B flat major utilising embodied analysis to explore how elements of Strinasacchi's concerto intersected with issues of gender in an eighteenth-century European context.

The source of Strinasacchi's Violin Concerto drawn on here is a copy currently held by the British Library (shelfmark GB-Lbl R.M.21.d.7, ff. 105-130). This handwritten set of parts - part of a bound collection of eleven works by various eighteenth- and nineteenth-century composers - was made and probably owned by one Johann Wilhelm ('William') Griesbach (1772-1825) and is dated 1798. At present this is the only known copy of Strinasacchi's concerto. It is not known how Griesbach came to have a copy of the concerto parts, but it is known that he was a Hanoverian-born string-player who worked as a member of the "Queen's Band" at the court of George III. ${ }^{1}$ He immigrated to England around 1785, joining several relatives already in the Band: perhaps he brought a copy of the concerto over to England with him, or a relative or friend sent it at his request. ${ }^{2}$ As Strinasacchi is not

${ }^{1}$ F. Anne M. R. Jarvis, "The Community of German Migrant Musicians in London c1750-c1850” (master's thesis, University of Cambridge, 2003), accessed 6 February 2015, http://www.maydwell.co.uk/german-musicians/dissertation/. 2 Ibid. 
known to have had any personal connection with England, this seems the more likely means by which the concerto would have arrived in Britain.

Little to nothing is currently known about the genesis of the concerto itself. Because the only known extant version is the Griesbach copy, and the concerto is not mentioned specifically in any sources found in the course of this research, it is ultimately not possible to pinpoint when, where, or why Strinasacchi composed or performed this concerto. Through drawing on research about Strinasacchi's historical context, however, it is possible to make some broad suggestions about the concerto's background and purpose. Like Lombardini Sirmen before her, Strinasacchi possibly learnt to compose during her time at the ospedale. The solo concerto was a natural genre for her to choose: as is well known, it was the primary means by which eighteenth-century virtuosi displayed their skills and garnered attention. ${ }^{3}$ In writing a concerto then, Strinasacchi was doing as her male colleagues did, though few other female violinists appear to have followed suit (Lombardini Sirmen excepted). There are two likely purposes for which Strinasacchi may have written this concerto: for one of her several tours around Italy and Germany, or for her patron Prince August once she had settled in Gotha. It appears that concerto was never published, but this does not necessarily mean that it was intended only for Strinasacchi's personal use. According to George B. Stauffer, "copying scores and performance parts by hand remained the most viable way of reproducing pieces quickly and economically" in the second half of the century. ${ }^{4}$ Thus the absence of publication is not necessarily an indication that the concerto received limited distribution: indeed, its presence in Griesbach's collection would seem to indicate otherwise.

What kind of audience might have heard Strinasacchi perform this concerto? Concert audiences at this time, though they were increasingly drawn from the middle classes, really involved only the upper third of society. ${ }^{5}$ Nevertheless there were a variety of groups with different social standing and levels of wealth from the upperand upper-middle classes represented, with the particular mixture varying according to geographical location. Listener/viewers also came with different levels of musical knowledge, and were broadly divided into three groups: amateurs (also dilettantes or

${ }^{3}$ Chappell White, From Vivaldi to Viotti: A History of the Early Classical Violin Concerto (Philadelphia: Gordon and Breach, 1992), 25.

${ }^{4}$ George B. Stauffer, "Introduction: J.S. Bach, the Breitkopfs, and Eighteenth-Century Music Trade," Bach Perspectives 2 (1996): 6-7.

${ }^{5}$ William Weber, “The Muddle of the Middle Classes," 19th-Century Music 3, no. 2 (1979): 182. 
Liebhaber in northern Germany), connoisseurs (experts or Kenner), and professionals. ${ }^{6}$ Those in the first two groups predominantly came from the upper echelons - they might play an instrument but would not perform for pay - and were thus of higher social standing than professional performers or composers. Non-working women of the middle classes and relatively well-off men employed in a profession other than music could also fall into these categories.

Though musicology has often privileged the perspectives of professionals and the Kenner over those of the Liebhaber, Yotan Bar-Yoshafat has argued that Liebhaber views should not necessarily be thought of as inferior: even during the late eighteenth century the two groups were not universally perceived in this way. ${ }^{7}$ This also extends to the reputation for inattention often associated with eighteenthcentury audiences, particularly women. According to Caryl Clark, writing about opera in eighteenth-century Vienna, "the spectacle of chattering female Burgtheater patrons need not diminish or tarnish the role of women as consumers of opera or signal their total disregard for what was being transmitted to them. Likewise, audience attentiveness does not always mean listening or comprehension; rather, occasional inattention may be a sign of engagement with immediate events." ${ }^{8}$ In other words, simply because certain musical features and modes of listening have traditionally been ascribed higher value than others, it does not in fact follow that they are any less valid means of engaging with music.

In the course of this chapter I look at Strinasacchi's concerto in its historical context, reflecting on it as a performance in the environment of the public concert rather than as an abstract "work." Considering this concerto as a performance enables me to explore how the gendering of violin-playing made it a complex undertaking for female violinists, in turn facilitating closer study of some of the issues encountered in the preceding chapters. A performance focus is arguably also a more appropriate approach for late eighteenth-century music, which belonged to an

\footnotetext{
${ }^{6}$ Yonatan Bar-Yoshafat, "Kenner und Liebhaber - Yet Another Look," International Review of the Aesthetics and Sociology of Music 44, no. 1 (2013): 20.

${ }^{7}$ Ibid., 30.

${ }^{8}$ Caryl Clark, "Reading and Listening: Viennese Frauenzimmer Journals and the Sociocultural Context of Mozartean Opera Buffa," The Musical Quarterly 87, no. 1 (2004): 146.
} 
environment in which "work" and "performance" were often not considered separable concepts. ${ }^{9}$

Because of the relationship of the body to issues of gender (both generally and in relation to Western art music in particular), I will consider not only the aural effects of these musical features, but also their visual effects when performed by a female violinist. I emphasise this aspect of performance because of the centrality of the performer's gendered body in responses to women violin players. Thus consideration of what George Fisher and Judy Locchead have termed performance gesture and its relation to gender in this context will flow through this analysis. ${ }^{10} \mathrm{I}$ focus on two kinds of performance gestures: those "necessary for sound production", and "coordinating and cuing activities", as these are physical movements that can be extrapolated from the only remaining trace of performance, the score. ${ }^{11}$

After presenting historical and recent musicological support for focusing on performance gesture, I elucidate my approach to four other musical aspects that will be considered: virtuosity, topics, structure, and soloist/orchestra interaction. I then turn to the analysis itself which proceeds through the three concerto movements in chronological order, moving between and often combining discussion of the six issues outlined above (gender, gesture, virtuosity, topics, structure, soloist/orchestra interaction).

What emerges is a concerto in which the composer/performer has wholeheartedly embraced the multiplicity of her position as an eighteenth-century female violinist. At once perceived as expressing both feminine and masculine traits in performance, the onstage female violinist came to be viewed as enacting an ambiguous mixture of genders. Strinasacchi's use of different musical features that were themselves considered to be gendered resulted in moments that affirmed the performer's femininity and others that implied her embodiment of masculinity.

\footnotetext{
${ }^{9}$ Lydia Goehr, The Imaginary Museum of Musical Works: An Essay in the Philosophy of Music (Oxford: Clarendon Press, 1992), 185-187.

${ }^{10}$ Fisher and Lochhead, "Analyzing from the Body," 47.

11 Ibid., 48.
} 


\section{Analytical Frameworks}

\section{Gender and Gesture}

Many elements of Strinasacchi's performance were imbued with gendered associations, first among them being that, as discussed in Chapter One, the instrument itself was seen as a man's instrument. The violin concerto as a genre (given the instrument's association with men) was thus also considered relatively masculine, with this sense being strengthened by its connection with professionalism and the public venue of the concert hall. Particular musical features, mainly structure and topic, also interacted with eighteenth-century ideas about gender in various ways The rondo, for instance, was perceived as a feminine form. ${ }^{12}$ Yet further layers are added when the performers' bodies are considered: performance of the solo violin part by a feminine-gendered body contrasted with the collective male-gendered body of the orchestra accompanying her. Though many of these features would generally have gone unremarked under "normal" circumstances (with a male solo violinist), when performed by a female violinist their gendered associations were highlighted. What was taken as standard when performed by a male violinist ceased to be invisible.

Turning first to consideration of performing bodies, a host of evidence from eighteenth-century sources indicates that eighteenth-century musicians felt performers' physical movements were of significance, thus lending the use of performance gesture historical applicability in this context. Opera is the most obvious musical context in which gesture played an important role: scholars such as Mary Ann Smart have explored how gesture not only interacted with text but with musical content. ${ }^{13}$ It is important to note that there are limited parallels between theatrical (and oratorical) gesture and those involved in violin-playing. As the primary function of violin gestures is a practical one - to produce sound - in order not to interfere with sound production the violinist is obviously much more restricted in the scope and variety of their movements than an opera singer. Despite the fact that violin gestures for the most part do not resemble other kinds of movements, concepts from theatrical and oratorical gesture do have some application. Referring

\footnotetext{
12 Matthew Head, “'Like Beauty Spots on the Face of a Man': Gender in 18th-Century North-German Discourse on Genre," The Journal of Musicology 13, no. 2 (1995): 155-157.

${ }^{13}$ Mary Ann Smart, Mimomania: Music and Gesture in Nineteenth-Century Opera (Berkeley: University of California Press, 2004).
} 
to Gilbert Austin's Chrironomia from 1806, Robert Toft has noted that "most gestures do not represent any particular sentiment but relate to the emotional quality of the text in a general way. Action derives its significance, then, not from the gesture itself but rather from the manner in which it is applied." "Th This holds true for violin performance. For instance, slow movements (such as the long slurred bows in the Adagio) visually communicate repose - likewise in calm phrases the singer or orator moves their arms and hands little and in a leisurely manner. Though I argue that violin gestures tend to communicate in a general rather than specific way, there is some overlap between these and theatrical/oratorical gesture, which will be discussed in relation to topics and structure.

Further sources show that gesture was important to non-operatic musical performance. In The Art of Musical Phrasing in the Eighteenth Century, Stephanie Vial discusses views on the topic from figures such as C.P.E Bach and Daniel Gottlob Türk. Crucially, though Vial focuses mostly on vocal performance, she shows that these writers addressed gesture specifically in the context of instrumental performance. C.P.E. Bach is more strongly committed to this task, stating in his Versuch (1753) that "those who maintain that all of this [affect] can be accomplished without gesture will retract their words when, owing to their own insensibility, they find themselves obliged to sit like a statue before their instrument." ${ }^{, 15}$ In other words, emoting with the body is essential to good performance, as without it the main purpose of music (conveying affect to and thus moving the audience) cannot be communicated effectively. Türk's comments in his Klavierschule (1789) show another side of the story, arguing that it does "not hold that such a pantomimic play in music contributes very much to expression as was formerly maintained." 16 This indicates that Türk felt some instrumental performers were by the 1780s relying too heavily upon the emotive capabilities of their physical bodies (as opposed to the "music itself'). Türk was proposing that this practice be reined in, though not banned outright: Vial adds that instead "Türk maintains that the countenance of the keyboard player should approximate the character of the composition in a decorous manner." ${ }^{\text {17 }}$

\footnotetext{
14 Robert Toft, "Action and Singing in Late 18th- and Early 19th- Century England," Performance Practice Review 9, no. 2 (1996): 157.

15 Quoted in Stephanie Vial, The Art of Musical Phrasing in the Eighteenth Century: Punctuating the Classical

'Period' (Rochester: University of Rochester Press, 2008), 68.

16 Ibid., 69.

17 Ibid.
} 
In addition to these late eighteenth-century sources, relatively recent musicological texts such as Le Guin's Boccherini's Body provide precedents for discussing performance gesture in eighteenth- and early nineteenth-century contexts. ${ }^{18}$ As Le Guin is a cellist, the physical processes she describes have some cross-over with violin-playing, and offer an example of how performers can draw upon their own embodied experiences of playing a piece to construct an analysis. Inspired by the approach of Le Guin, as well as Helyard, DeNora, and Fisher and Lochhead, I utilise my own experience as a female violinist and also a listener/viewer in this analysis in order to discern what kind of physical gestures Strinasacchi may have made in performance. Through this I explore what her audience may have seen and what the combination of sounds and performance gestures originating from a female violinist might have meant to them. As Le Guin acknowledges in relation to Boccherini, this type of reconstruction is in many ways a fictive exercise - we cannot really know what or how Strinasacchi and her eighteenth-century listener/viewers heard, saw, or interpreted. ${ }^{19}$ Nevertheless, there is much to be discovered by thinking about the body that first played these notes, and that is sometimes best done by trying out those roles yourself.

My decision to focus on how Strinasacchi's performance may have been received and interpreted, rather than on her imagined subjective experience, may appear to downplay her agency. In fact, my decision to emphasise potential audience response stems from a desire to give her as much agency as possible: I have not constructed my analysis around a projection of what Strinasacchi hypothetically experienced because I do not wish to claim that I speak for her. By considering the concerto from the perspective of an imagined audience I am able to explore important aspects of Strinasacchi's performance without re-enacting the historical silencing female violinists have often faced by putting my words in her mouth. An additional motivation for this decision was that there is very little primary material from which an idea of Strinasacchi's personality and subjective experience could be constructed: only one letter in her hand and three or possibly four silhouettes

\footnotetext{
${ }^{18}$ Futher examples - which also explore gender in relation to performance gesture - include Tia DeNora, "Embodiment and Opportunity: Bodily Capital, Gender, and Reputation in Beethoven's Vienna," in The Musician as Entrepreneur, 1700-1914: Managers, Charlatans, and Idealists, ed. William Weber (Bloomington, IN: Indiana University Press, 2004), 185-197; Helyard, "Muzio Clementi, Difficult Music, and Cultural Ideology."

${ }^{19}$ Le Guin, Boccherini's Body, 12-13.
} 
(including the one from 1795) are readily available. ${ }^{20}$ This situation might change with focused archival research, but such research was not within the scope of this study. Lacking such material, it was therefore necessary for me to ground my work in the score, my own violin-playing experience, contemporary accounts of female violinists, and (as those accounts are often vague) scholarship regarding other kinds of eighteenth-century female instrumentalists.

\section{Musical Features for Analysis}

In addition to the wide reaching issues of gender and performance gesture, a slightly less typical approach to this piece than a focus on form and harmony was required as, for a number of reasons, it might be seen as inferior when viewed using mainstream criteria. Firstly, it is a concerto (a genre maligned for its foregrounding of virtuosity), and it is by a little-known composer doubly devalued due both to her gender and to her reputation as a performer first and foremost. Furthermore, Strinasacchi's concerto is Italianate: melody-focused, dominated by light accompaniment in thirds, with short and clear phrases, much variety between phrases, and modulations that never stray far from the tonic. Thus I have focused on the features of virtuosity, topics, structure, and soloist/orchestra interaction.

Though it is not my intention to make claims of greatness on behalf of this concerto, using tools which focus on its inadequacies would ignore what interesting insights it has to offer in relation to eighteenth-century women's violin performance. It is also worth noting that though the Italianate features listed above were often viewed negatively by many eighteenth- and nineteenth-century German critics, this does not mean that listeners with different kinds of musical knowledge felt the same way. Indeed quite the opposite: these musical attributes were highly popular among general eighteenth-century concert audiences, and criticisms from specialist German writers were frequently motivated by non-musical concerns such as nationalism. ${ }^{21}$

\footnotetext{
${ }^{20}$ In addition to the 1795 silhouette there is a head-only silhouette _ in an album amicorum owned by Schade and another held by the New York Public Library. A silhouette by Böttger was also mentioned in the Allgemeine Literatur Zeitung in 1796, which may or may not be the same artwork at that held in New York.

${ }^{21}$ Mary Sue Morrow, German Music Criticism in the Late Eighteenth Century: Aesthetic Issues in Instrumental Music (New York; Cambridge, U.K: Cambridge University Press, 1997), 48-50.
} 
For these reasons, I have chosen to focus on musical elements that interact with the issues of gender and gesture in interesting ways.

\section{Virtuosity}

Though the majority of research on virtuosity has so far focused predominantly on the nineteenth century, it is possible to draw some conclusions about musical virtuosity in the eighteenth century. Firstly, there are two primary kinds of virtuosity: technical prowess, which on the violin usually involves the use of features such as fast passagework and high positions; and beautiful sound production, shown primarily in melody-driven passages. ${ }^{22}$ Theorists of the day effectively saw virtuosity of the technical display kind as the direct opposition of true feeling. ${ }^{23}$ Thus highly virtuosic music eschewed what many considered the central aim of music: to move the passions. Because of this, virtuosi were often cast as machine-like and inhuman, lacking in the ability to express true sentiment, and consequently virtuosic feats were considered easier to perform than music that moved the soul. ${ }^{24}$ It is important to note here that a number of scholars have shown that much anti-virtuosic sentiment stemmed from musicians and composers reacting to others in their field. ${ }^{25}$ As such there was almost certainly an element of professional jealously wrapped up in seemingly noble statements. Aside from a perceived threat felt by some musicians, the focus that virtuosity put on the body rendered such musical performances earthly, akin to lower class forms of entertainment such as circus acts. ${ }^{26}$ This made musical performance a craft (i.e. laborious) more than an art and, crucially, took the focus off the "music itself." 27 The role that the visual played in virtuosic performance is thus highlighted in many accounts, with prioritisation of the visual being correlated with superficiality. ${ }^{28}$ Finally, particularly with regards to singing and violin-playing,

\footnotetext{
22 White, From Vivaldi to Viotti, 89.

${ }^{23}$ Le Guin, Boccherini's Body, 136-138.

${ }^{24}$ Ibid.; Helyard, "Muzio Clementi, Difficult Music, and Cultural Ideology," 46.

${ }^{25}$ Dana A. Gooley, "The Battle against Instrumental Virtuosity in the Early Nineteenth Century," in Franz Liszt and His World, ed. Christopher Howard Gibbs and Dana A. Gooley (Princeton: Princeton University Press, 2006), 76; Cliff Eisen, "The Rise (and Fall) of the Concerto Virtuoso in the Late Eighteenth and Nineteenth Centuries," in The Cambridge Companion to the Concerto, ed. Simon P. Keefe (Cambridge: Cambridge University Press, 2005), 189-190.

${ }^{26}$ Gramit, Cultivating Music, 141; Le Guin, Boccherini's Body, 134.

${ }^{27}$ Gramit, Cultivating Music, 141-142; Eisen, “The Rise (and Fall) of the Concerto Virtuoso,” 189.

${ }^{28}$ Le Guin, Boccherini's Body, 137-138.
} 
virtuosity was inherently connected to Italian music and musicians, lending criticism by non-Italians a xenophobic edge. ${ }^{29}$

The widespread popularity of Italian virtuosi and their performance styles however confirms that this prejudice was mainly held by specialists - professionals and possibly the Kenner - and was a view that, according to Dana Gooley, was later "imposed upon a public that was initially gravitating toward music of virtuoso character.. ${ }^{30}$ For the Liebhaber, then, virtuosity held great appeal: its ability to arouse wonder and astonishment (seen by theorists as suspicious) held what Le Guin suggests was a seductive power. ${ }^{31}$ Undoubtedly, this seduction in part stemmed from virtuosity's rootedness in the physical and the visual. According to Le Guin, wonderinducing virtuosic feats cause a sense of alienation in the listener/viewer. This alienation - or Othering - can render a body inhuman and has the ability to both repulse and seduce. ${ }^{32}$ Furthermore, it can lead to objectification of the virtuosic body (hinted at by commentators' comparisons of virtuosi to machines).

Thus there is some overlap in the anxieties surrounding the display of the body in virtuosic music and in women's (paid and unpaid) performance. As virtuosity was associated with professionalism, and women's musical performance was so closely tied to amateurism, the domestic sphere, and the ideal of stillness, women enacting virtuosity (primarily as keyboardists) could be seen as embodying masculinity. ${ }^{33}$ Women who did this faced criticism similar to that of male virtuosi, but fast finger action at the keyboard in particular (and its association with the mechanical) came to be closely linked to female performance and was often termed "rattling." 34 In terms of women's violin-playing, a number of commentators expressed surprise at how well certain violinists were able to play. ${ }^{35}$ This implies that their expectations of female violinists perhaps aligned with expectations around women's performance more generally - that virtuosity was not part and parcel of it. On the other hand, Gillen D'Arcy Wood has argued that through the link between virtuosic performance

\footnotetext{
${ }^{29}$ Ibid., 137.

${ }^{30}$ Gooley, "The Battle against Instrumental Virtuosity in the Early Nineteenth Century," 104.

31 Matthew Riley, Musical Listening in the German Enlightenment: Attention, Wonder and Astonishment (Burlington; Aldershot: Ashgate Pub. Co, 2004), 31-32; Le Guin, Boccherini's Body, 138.

32 Boccherini's Body, 138.

33 Tia DeNora, "Music into Action: Performing Gender on the Viennese Concert Stage, 1790-1810," Poetics 30, no. 1 (2002): 19-33.

${ }^{34}$ Hohl Trillini, The Gaze of the Listener, 66, 74.

35 See for instance two reviews of Strinasacchi in Cramer's Magazin der Musik (1783), quoted in Timmermann, "Strinasacchi, Regina".
} 
and the aristocracy, characterised by emerging bourgeois culture as effeminate, virtuosity itself came to be considered by some as effeminate, particularly through the idea that it constituted "useless labour." ${ }^{36}$ The presence of virtuosic sounds and physical movements in Strinasacchi's concerto thus brings up interesting issues surrounding gender and virtuosity (especially on a masculine instrument), making consideration of these musical feature vital to my analysis.

\section{Topics}

Though eighteenth-century listeners did not use the term "topic," and some scholars dispute the historical basis for topic theory, others argue that eighteenthcentury listeners were very familiar with and comprehended the use of topics such as the march, various dances, the pastoral, singing style, and numerous others. ${ }^{37}$ Here, a topic is defined as "a familiar style type with easily recognisable musical features" that is "taken out of [its] proper context and used in another way.", It is thought that particularly the mixing of topics played a significant role in making much late eighteenth-century music not only intelligible but enjoyable (and thus pleasurable) for audiences, and is thus integral to this music's sociability. ${ }^{39}$ The trend toward the mixing of topics in instrumental music in the second half of the century meant that large works were essentially "music made out of music," and considered indicative of Italian style. ${ }^{40}$ The origins of this style have been linked to opera buffa and the mixed style's comic nature was frequently touted as a negative turn for instrumental music by German commentators. ${ }^{41}$ Topics also encompass "imitation of extra-musical sounds." 42

Numerous topic theorists have explored the ways in which musical gestures can emulate physical movement (musical gestures being "the sonically oriented concept"

\footnotetext{
${ }^{36}$ Wood, Romanticism and Music Culture in Britain, 6, 2-4. Note: effeminacy is not the same as femininity - see Head, "Like Beauty Spots on the Face of a Man," 148-150.

${ }^{37}$ Danuta Mirka, "Introduction," in The Oxford Handbook of Topic Theory, ed. Danuta Mirka (Oxford: Oxford University Press, 2014), 2, 28; Melanie Lowe, Pleasure and Meaning in the Classical Symphony (Bloomington: Indiana University Press, 2007), 27-28.

38 Robert S. Hatten, “The Troping of Topics in Mozart's Instrumental Works," in The Oxford Handbook of Topic Theory, ed. Danuta Mirka (Oxford: Oxford University Press, 2014), 514; Danuta Mirka, "Introduction," ibid., 2.

39 "Introduction," 43.

40 Allanbrook quoted in ibid., 28; ibid., 6.

41 Ibid., 9.

${ }^{42}$ Ibid., 35-36.
} 
rather than the physical movements of performers). ${ }^{43}$ Few have considered how musical gesture and its relation to topics might interact with performance gestures. ${ }^{44}$ At particular points throughout this concerto, I consider how actual performed physical gestures might interact with topics, showing that they often heighten the listener/viewer's experience of particular topics and the associations these topics evoke. Some theorists, such as Melanie Lowe, have argued that certain topics functioned as indicators of structure, allowing less musically educated listeners to follow along with a movement's progress. ${ }^{45}$ Topics such as the French overture (dotted rhythms, slow, grand) frequently signal openings, minor keys (in predominantly major key movements) can signal sections of continuation, while horns can signal closure. ${ }^{46}$ If physical gestures produced by particular topics can help communicate those topics, and certain topics can convey structure, I posit that certain gestures can also convey aspects of structure. In this analysis I will primarily focus on "commencing" topics and gesture, linking one particular gesture with basic movements found in eighteenth-century theatrical practice.

\section{Structure}

I spend little time in this analysis on structure in and of itself - I am more concerned with how it interacts with other musical elements. A lighter emphasis on large-scale structure in the traditional sense (e.g. first movement sonata form) is also arguably more historically appropriate for Italianate music of this era. As Le Guin (and others) have explored, tools designed for later Viennese music simply do not work well for other repertoires. ${ }^{47}$ Alternative approaches have been proposed by Lowe, Robert Gjerdingen, and Mary Sue Morrow. Lowe argues that consideration of the broad categories of openings, middles, and closings - as opposed to a nonchronological, out-of-time approach - is more applicable to a musical culture in which instrumental pieces were often heard only once. ${ }^{48}$ Such general markers are quite easily discernible while experiencing a musical performance as it happens.

43 Ibid., 47-48; Fisher and Lochhead, "Analyzing from the Body," 47.

44 An exception is Mary Hunter who has alluded to a connection. Mary Hunter, "Topics and Opera Buffa," in The Oxford Handbook of Topic Theory, ed. Danuta Mirka (Oxford: Oxford University Press, 2014), 68.

${ }^{45}$ Lowe, Pleasure and Meaning, 29.

46 Ibid., 30-32, 49, 26.

${ }^{47}$ Le Guin, Boccherini's Body, 26-27.

48 Lowe, Pleasure and Meaning, 23-24. 
Thinking about structure in this way constitutes more of a continuous flow approach. Gjerdingen suggests that this was possibly the kind of listening employed by eighteenth-century audiences. ${ }^{49}$ Similarly, Morrow indicates that detailed aspects of large-scale structure were at this time more the prerogative of theorists than the Kenner or Liebhaber. Even in the writings of eighteenth-century theorists the importance of form did not really begin to gain strength until the end of the 1780s. Rather, in the 1770s and early 1780s, "musical structure depended more on the logical progression of small musical ideas than it did on abstract unity or concrete form. ${ }^{.50}$

In this approach to composition the eighteenth-century requirement for music to be sociable, a burden placed upon the composer rather than the listener, is visible. In Strinasacchi's concerto, there is an emphasis on clarity and comprehensibility from bar to bar and phrase to phrase that show she aimed to bring her less musically educated listeners along with her. This is particularly apparent in the solos, which are dominated by repeated two-bar units. Furthermore there is very little development or recasting of earlier material in a Mozartian sense. ${ }^{51}$ Though this approach, which favours clarity "at the price of grace" can lead to "continuity [which is] choppy and short-breathed," and came to be frowned upon as simplistic as ideologies changed, White indicates that it was certainly not an unusual feature for violin concerti of this period. ${ }^{52}$ What this approach does enable is contrast and variety in melody, rhythmic ideas, and affect - important, as variety was touted by theorists like Johann Sulzer as key to sustaining a listener's pleasure and attention. $\quad{ }^{53}$ So while clarity is perhaps sometimes valued over smoothness and overall unity in this concerto, these features reflect the values of Strinasacchi's musical context, and show a desire on her part to engage with many of her listener/viewers in a comprehensible way.

Though moment-to-moment consideration might be more appropriate for this concerto, as large-scale form is such a part of the discourse surrounding late eighteenth-century music, and because standard forms can be mapped onto this

${ }^{49}$ Robert O. Gjerdingen, Music in the Galant Style (Oxford; New York: Oxford University Press, 2007), 424.

50 Morrow, German Music Criticism, 87.

51 This one-idea-to-the-next approach is one that Head has also noted in relation to a rondo by Sophia Westenholz. Head, Sovereign Feminine, 174.

52 Chappell White, “The Violin Concertos of Giornovichi," The Musical Quarterly 58, no. 1 (1972): 76, 91-92.

53 Matthew Riley, "Civilizing the Savage: Johann Georg Sulzer and the 'Aesthetic Force' of Music," Journal of the Royal Musical Association 127, no. 1 (2002): 16. 
concerto, I lay out the structure of each movement at the beginning of each movement discussion. The analysis as a whole progresses in a broadly chronological fashion, but in the interest of clarity and to avoid extraneous bar-by-bar description, I move between moment-to-moment description and a more out-of-time approach, where I have deemed this to be appropriate.

\section{Soloist/Orchestra Interaction}

The interaction between soloist and orchestra was, along with virtuosity, a key attraction of the concerto genre. In relation to this concerto, it also seems possible that the novelty of seeing a female violinist interact with a (male) orchestra may well have been a significant part of the appeal for audience members unaware of Strinasacchi's fame as a virtuoso. If visual spectacle was already a mainstay of the concerto genre due to the requirement of virtuosic display, then adding a further spectacle in the form of an unusual soloist would have been an additional draw card consistent with the genre's emphasis on inspiring awe. Seeing Strinasacchi side by side with male violinists (musicians of the "correct" gender) may have heightened the sense of wonder created by the discord between her body, her instrument, and her gestures through the visual comparison.

The issue of leadership is of particular importance in the interaction of the two parties. The dual orchestral leadership model (with both keyboardist and first violinist working together) was common throughout the century, but the first violinist was increasingly favoured. ${ }^{54}$ It was also standard practice for the solo violinist to play the first violin part and thus act as leader during tutti sections, especially if they were the composer. ${ }^{55}$ Common practice therefore places Strinasacchi as leader of an all-male ensemble not only as a distinct figure, but as one that is frequently integrated into the ensemble through her playing of the first violin part. She is both separate and assimilated, an individual woman soloist and a member of the male orchestral collective. This complicates Green's argument that women performing as orchestral players are even less likely to affirm their femininity than

\footnotetext{
${ }^{54}$ Spitzer and Zaslaw, The Birth of the Orchestra, 392-393.

${ }_{55}$ Robin Stowell, "Performance Practice in the Eighteenth-Century Concerto," in The Cambridge Companion to the Concerto, ed. Simon P. Keefe (Cambridge: Cambridge University Press, 2005), 225.
} 
soloists, as they must work with the male collective and become "one of the men." Of course, in the context of a concerto, it is visually and aurally clear when the soloist is acting as such, and when they are acting as a first violin. Nevertheless, in Strinasacchi's case, these two seemingly exclusive roles were likely embodied by the same woman. This blurred the distinction, putting Strinasacchi in two masculinegendered roles (leader and orchestral player) simultaneously, with the role of member of the orchestra potentially questioning traditional musical gender roles even more than that of solo violinist.

Strinasacchi's role as leader within the "music itself" is also of importance. Musical interaction between soloist and orchestra in concerti usually refers to exchange and development of thematic material. There is minimal dialogue or exchange of thematic material in this concerto (really a feature of concerti by German, rather than Italian, composers), making moments where active dialogue does occur stand out. The matter of who says what first is also of significance. Through monopolising musical material, the solo violin asserts her metaphorical and actual role as leader, challenging expectations regarding women's roles both in ensemble music-making and perhaps also more generally.

\section{Analysis of Strinasacchi's Violin Concerto}

\section{Allegro Moderato}

The Allegro of Strinasacchi's concerto is in ritornello-sonata form and follows many of the formal conventions of concerto first movements from the 1770s and $1780 \mathrm{~s}^{57}$ As is typical for the era, though the labels of exposition, development, and recapitulation can be mapped on to the Allegro, these do not fit neatly. This is especially the case in the "development"/second solo episode in bb. 112-158: as is common for non-Austrian concerti, there is no real recasting or working out of earlier material here. ${ }^{58}$ The ritornello principle is thus clear in this movement, with alternations between (four) tutti and (three) solo sections.

\footnotetext{
${ }^{56}$ Green, Music, Gender, Education, 68.

57 White, "The Violin Concertos of Giornovichi," 74-75.

58 Ibid., 76.
} 
The Allegro contains numerous musical features and performance gestures which suggest that an eighteenth-century conception of a masculine-gendered performance style dominates. Strinasacchi's fulfilment of a masculine role, specifically that of leader of the orchestra, is reinforced by the solo violin's takeover of formerly tutti material in the recapitulation section. Opening and closing gestures - preparatory bow movements, coup d'archet, and final flourishes - visually illustrate basic elements of the movement's structure, and the fact that Strinasacchi likely would have led these movements in performance emphasises her leadership role. Masculine-gendered violin-playing is found in "vulgar" displays of virtuosity: large leaps, extreme "grand" cadences, and passages in high registers. The use of fast mechanical and pianistic passagework however hints at a feminine-coded virtuosity.

The opening tutti begins with a coup d'archet, elongated by a pause and rendered particularly grand by the rest which follows immediately after it in b. 1 (see example 1.1 below). ${ }^{59}$ This rest separates the coup d'archet from a light and playful melody featuring syncopation in b. 6, which is itself interrupted by a clipped French overture exclamation in bb. 10-11, though the syncopated melody returns soon after. Lowe argues that, in music of this period, the French overture topic and the coup d'archet figure signal opening and as such serve a structural function - the first traditionally served as courtly "ceremonial entrance music," while the second loudly tells otherwise occupied audience members that the piece has started. ${ }^{60}$ Before the first note had sounded though, gestures would have alerted listener/viewers to the start of the concerto being imminent: the orchestra would raise their instruments to their shoulders or lips, and the string players would hold their bows at the ready above the string. The solo violinist/leader might then beat the tempo with their bow or scroll in order to cue the orchestra for the unison first note. ${ }^{61}$ So without even producing sound, gestures clearly indicate opening, and thus indicate structure. The gesture of the coup d'archet itself also communicates the opening function of this two-note figure: the orchestra (particularly of course the strings' bows) are not just aurally but also visually unified, signifying the association of this figure with "authoritative control" in more than one way. ${ }^{62}$ The starting position for the violin

\footnotetext{
59 James H. Johnson, Listening in Paris: A Cultural History (Berkeley: University of California Press, 1995), 78.

${ }^{60}$ Lowe, Pleasure and Meaning, 30-32.

${ }^{61}$ Spitzer and Zaslaw, The Birth of the Orchestra, 391-392.

${ }^{62}$ Janet Levy quoted in Lowe, Pleasure and Meaning, 32.
} 
bows here also happens to mimic theatrical and oratorical "commencing" gestures. According to Toft, a "period commences by raising the hand from rest to a place no higher than the downward or horizontal position of the arm" - a very similar position to where the right hand must move to in order to begin the up bow of this movement in the middle or lower half. ${ }^{63}$ Furthermore, because of the placement of the rest directly after the coup d'archet, Strinasacchi must cue the orchestra twice. Her gestures train the eyes of the orchestra and indeed the audience on her body in a truly commanding manner right from the outset of the concerto. ${ }^{64}$

The second and third tutti sections share much material with the first, but particularly in the third there are crucial differences (see examples 1.1 and 1.2 below). Here the solo violin takes on several phrases originally played by the orchestra: this can be seen as the soloist asserting her role as leader. Dialogue between the parties is also at its most active here. The first phrase (bb. 159-163) proceeds exactly as it did in the expositional section, but in the consequent phrase, rather than the solo and first violins playing in unison as they did initially, the soloist takes charge of the melody line. Meanwhile, the first violins take over the accompaniment line previously delivered by the seconds, the seconds take over the viola line, and the violas drop out altogether. The whole ensemble joins in again in bb. 168-169 for a French overture statement, but immediately after this in bb. 170-172 the same changes in part distribution are repeated. In the exposition, this is followed by a grand forte section (bb. 15-18), a contrasting piano section (bb. 19-22), and a three-bar crescendo (bb. 23-25). In the recapitulation, however, this is replaced by another solo episode (bb. 173-195) that introduces new material (mainly passagework in bb. 173-176) but which also plays on expositional material. For example, in bb. 180-183, the solo violin takes on the appoggiatura-laden phrase from bb. 26-31 and presents it up the octave and with a semi-quaver variation in b. 181, while the first violins join in a tenth below with an unornamented version of the melody.

${ }^{63}$ Toft, "Action and Singing in Late 18th- and Early 19th- Century England," 156.

${ }^{64} \mathrm{I}$ am grateful to Erin Helyard for suggesting this point. 

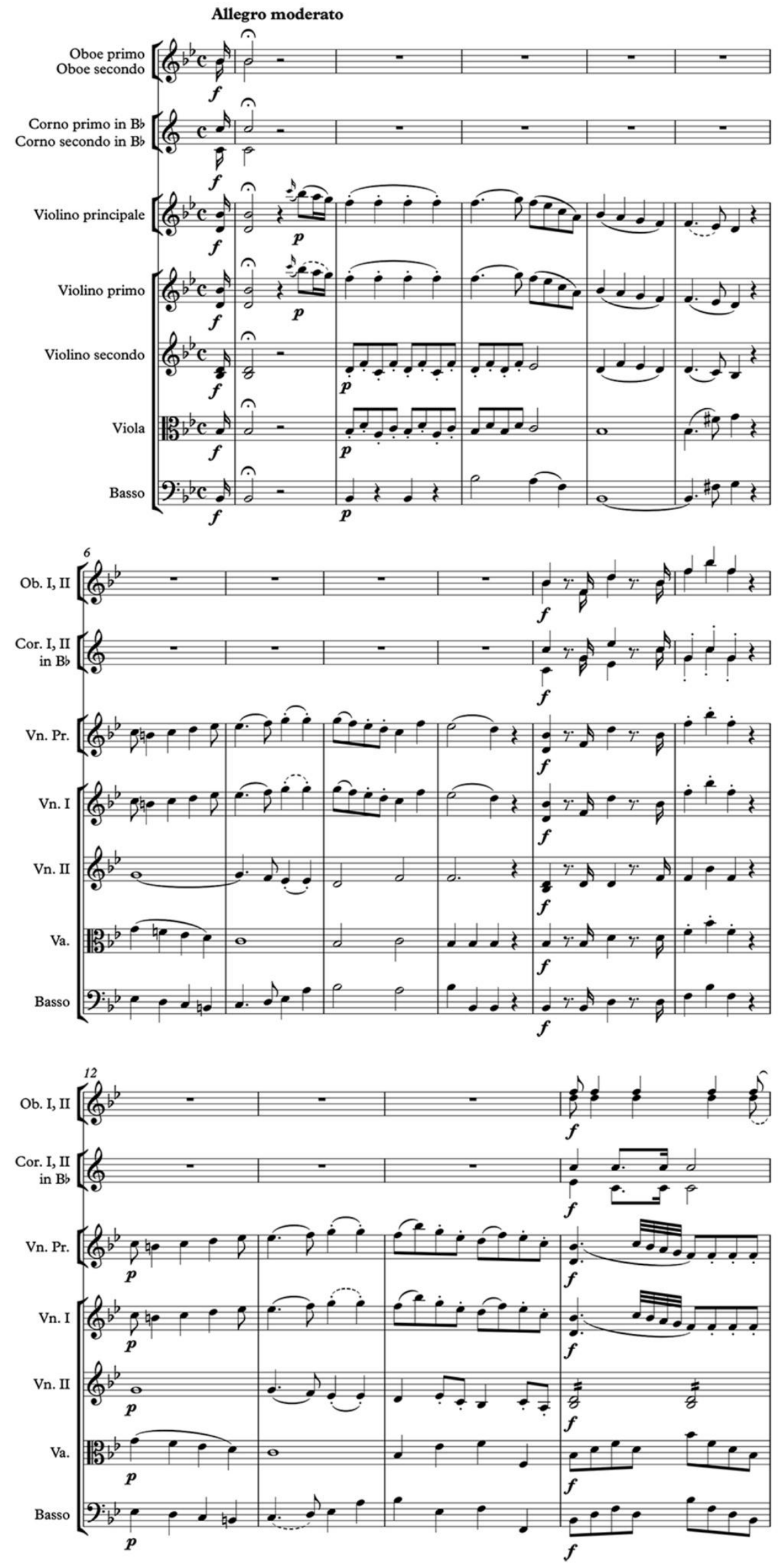

Example 1.1 Exposition 

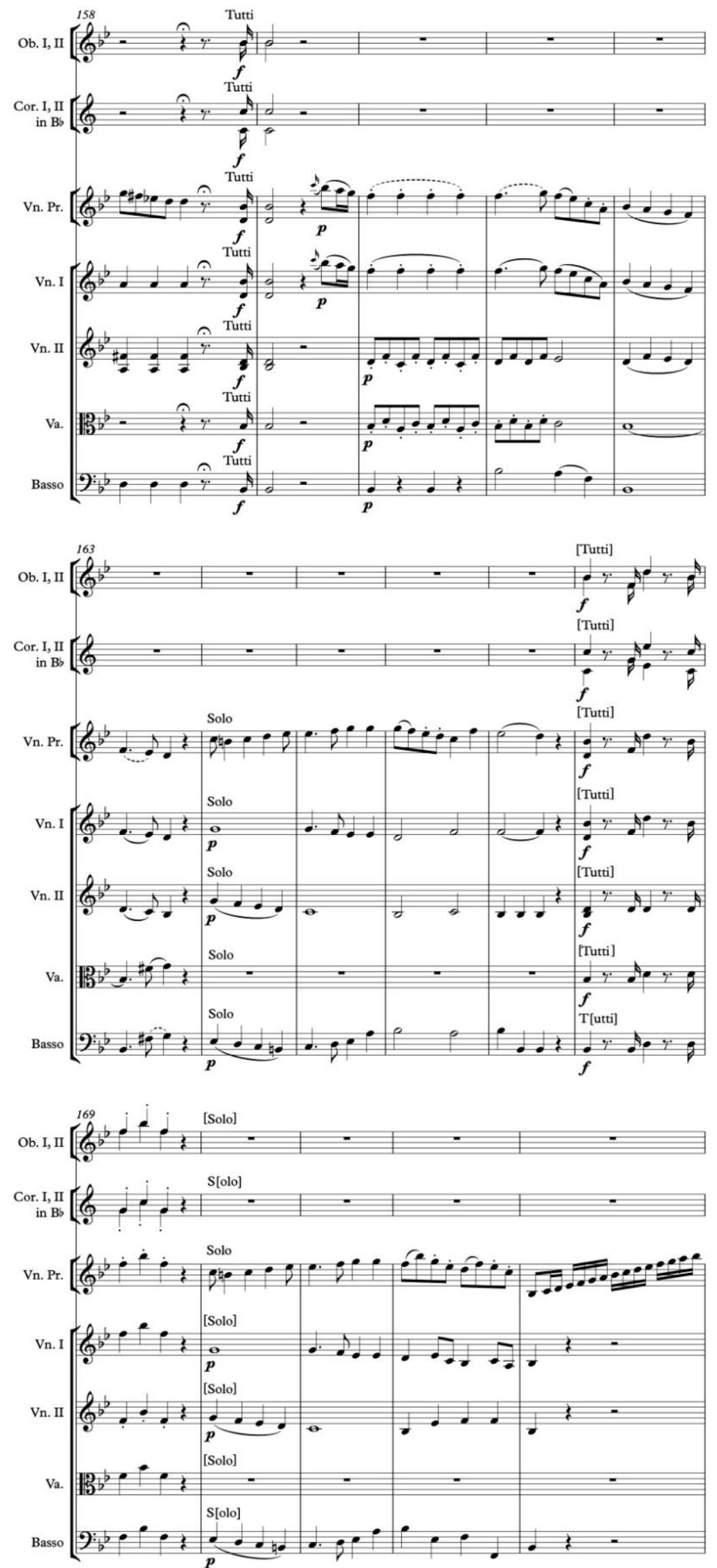

Example 1.2 Recapitulation 
A further difference between the exposition and recapitulation is that the latter is infused with more drama: the third bar (b. 182) now contains a quaver rest and a precipitous "grand cadence" drop (discussed below), the crotchet-length cadential trill has been extended to a minim, and the phrase ends with an unsatisfying imperfect authentic cadence in bb. 183-184. The whole phrase demands repetition to bring the solo episode to a more effective close. The solution Strinasacchi provides is a longer and grander cadential build up (made thus through the use of longer note values), an even longer trill (now a semibreve), and the anticipated perfect authentic cadence. The subsequent tutti section is effectively a coda: it reinforces the arrival of the final cadence in the tonic and is an exact repetition of bb. 23-42, involving the whole ensemble in a grand fashion.

Through these changes, the solo violin has dismantled the strict separation between solo- and orchestra-focused sections adhered to during the rest of the movement. In doing so, she has asserted her leadership, and also questioned the individual/group divide. By taking over the consequent section of each period in the opening of the recapitulation (bb. 164-167 and 170-172), she provides the metaphorical answers to the orchestra's questions (bb. 159-163 and 168-169). The violinist then takes the helm alone by diverting off into new virtuosic material. She also leads the way to reintroducing expositional material in b. 180 with sequential repetition in bb. 177-179, while the orchestral strings emphatically state their support by mirroring the solo part and outlining chord I. In b. 179, the continuous quavers in the firsts and basses echo their accompaniment in b. 26 , providing a subtle reminder of and additional momentum for launching into the variation of the appoggiatura figure in b. 180 .

This musical takeover on the part of the violinist confirms her leadership role and it also further blurs the boundary between what musical turf belongs to the soloist and to the orchestra. Strinasacchi's roles as visual leader of the ensemble (as concertmaster) and musical leader have also been merged into one here. In looking to the rhetoric espoused by male orchestral musicians in the late nineteenth century, when the number of women violinists had grown exponentially and there were calls for orchestras to begin employing them, it is apparent that the idea of a woman entering an orchestra was seen as an intrusion on a distinctly male sphere. ${ }^{65}$ Though

${ }^{65}$ Gillett, Musical Women in England. 
the number of women orchestral musicians was not at all sufficient to warrant them being seen as a threat to men's jobs in the late eighteenth and early nineteenth centuries, Strinasacchi's musically and visually evident move into that sphere in this concerto could have been seen in a similar light.

The solo episodes of the Allegro focus primarily on brilliant style virtuosity, foregrounding fast passagework, high positions, and vertiginous leaps in both the left hand and the bow. The presence of fast passagework here is perhaps one of the least provocative kinds of virtuosity Strinasacchi could have used as a female musician. I suggest this because it is in passagework that a violinist can, gesturally speaking, most closely resemble a pianist (specifically, the movements of the left hand fingers become visually like those of a pianist). Because the keyboard was considered a feminine instrument, and fast, finger-centric movement was an accepted part of that instrument's gestural vocabulary, the gestures of fast passagework in violin-playing fall more readily within the established limits of eighteenth-century female music making. More than one account of Gautherot's London performances show that eighteenth-century audiences saw passagework in the playing of female violinists in this light, with one saying "she bows but feebly, but she has a rapid and brilliant left hand, that overcame many difficulties." ${ }^{66}$ Susan Burney's criticisms of Gautherot mentioned earlier, and which are summarised by her statement that Gautherot's best playing was "rather brilliant than touching" - were very similar to those aimed at women keyboardists. ${ }^{67}$

In fast passages on the violin, the left hand fingers have to strike the fingerboard with precision and strength - more so than at slower tempos, so that the notes can speak properly. Rapidly striking or "rattling" fingers can both feel and look mechanical: they visually resemble and fulfil a similar function to the hammers of a fortepiano. ${ }^{68}$ This hammering action is echoed by the right arm movement required for executing fast, separate quavers: the bow and right hand/lower arm also make vigorous striking actions that move diagonally. The way one learns and retains the ability to execute these figures at speed is also, to a certain extent, "mechanical": they

\footnotetext{
${ }^{66}$ World and Fashionable Advertiser, 10 February 1789. Timmermann, "Gautherot, Louise". ${ }^{67}$ Quoted in Woodfield, Salomon and the Burneys, no. 12, 42.

68 Of course, with a fortepiano the action of the hammers striking the string actually produces sound, whereas on the violin the left hand fingers only alter the pitch (while the bow produces the sound). Nevertheless, as the violinist's left hand is highly visible in performance, the link between left hand action and sound production is strong.
} 
must be ingrained in muscle memory and are in that sense "automatic." Moments where such mechanical virtuosic gestures appear in Allegro include bb. 77-80, 117119 and 121-125, 126-130, 173-176. These passages involve strings of semiquavers, often in repetitive scalic (e.g. bb. 79-80 and 173) or arpeggiated (bb. 126 and 128) patterns, but also in stock patterns such those found in the second half of b. 118 and in b. 174 .

In a number of places, vertiginous leaps link high position work to passages near the bottom of the violin's range. The biggest leaps of this kind in the Allegro occur in b. 55 and b. 57 (f "' to b b'), and 182 and 189 (b b'" to e'). A different treatment of this virtuosic technique occurs in b. 76, which contains not one but two consecutive leaps ( $e^{\prime}$ to $g^{\prime \prime \prime}$ to $b$ b) and leads into fast passagework on the G, D, and A strings in bb. 7781 (see example 1.3 below). These leaps necessitate large and highly visible gestures on the part of the violinist. In most cases either the left hand must quickly dive from one end of the fingerboard to the other, or left hand and bow must jump laterally from the E string to the D or even the G. In b. 76 there is an example of these left and right arm gestures occurring simultaneously: while the left hand leaps from first position on the $\mathrm{D}$ string to sixth position on the $\mathrm{E}$ and back down to first position on the $\mathrm{G}$, the bow also generates large arm gestures. If I end b. 75 with a down bow, due to the crotchet-length slur I am at least at the midpoint if not closer to the tip for the up bow at the beginning of b. 76. Because the second note of the bar is both a minim and on the E string, I must launch this first up bow with speed and, simultaneously, quickly lower the level of my right arm, so that my bow starts the next note both at the heel and on the correct string. In order to get down to b b', I must swing my right arm upwards, skipping both the A and D strings, so that the tip of my bow lands on the $G$ for the final crotchet.

Harmonically, the first stratospheric leap seems to create a momentary sense of stasis as the minim (metaphorically) hangs suspended at the top of chord V in the dominant (F major). Underneath the solo violin, the orchestral violins and basses calmly continue their repeated quavers from the previous bar, and after the action of the high position work in bb. 70-74 and exciting descent and rhythmic variety in b. 75 in the solo violin, b. 76 seems full of anticipation without forward momentum. What, after all, could follow such a brazen jump on the high wire? Strinasacchi undermines our anticipation of something even more exciting in b. 77 by changing 
tack and diving into sprightly semi-quaver movement in an elaboration of chord $\mathrm{V}$, passagework which stays uncharacteristically low by utilising only the $G$ and D strings. Put simply, b. 76 is aural and visual spectacle.

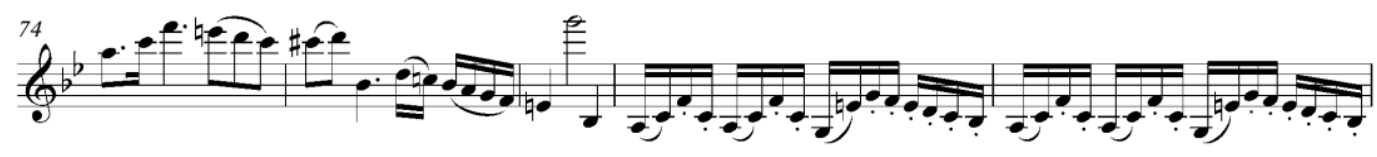

Example 1.3 Vertiginous leaps

Vertiginous leaps of a slightly different kind to those seen in b. 76 occur in Strinasacchi's use of the gravity-defying "grand cadence." This is a term adapted from Robert Gjerdingen's Music in the Galant Style by Floyd Grave, and is described by Grave as involving "a fast climb to a melodic peak... a precipitous drop on the following downbeat; a final approach to the cadence from above, energized by a trill over dominant harmony; and the structurally salient close itself." ${ }^{\text {"99 }}$ Grave is primarily discussing the use of the schema in Haydn's string quartets, and he argues that the composer's use of the exaggerated feature is not only comic but also didactic in function. More specifically, these often out-of-place drops can be seen as a lesson in the appropriate limits of eighteenth-century taste: leaps such as these are too brazen.

Two examples of extreme grand cadences are on show in bb. 182-184 and bb. 189-193, at the very end of the last solo section of the Allegro (see examples 1.4 and 1.5 below). In b. 182 we see the quick ascent to the peak followed by the extreme drop (though this does not fall on the downbeat of the next bar, the quaver's anticipatory nature produces the same effect), followed by a trill in b. 184 and partial resolution in the form of an imperfect authentic cadence. The second attempt at the grand cadence is a repeat of the first with several changes that make this resolution much more satisfactory. There is a two-bar extension between bb. 190-193 (which builds anticipation as it diverges from the plan laid out in bb. 182-184), the trill now lasts for a whole rather than a half bar, and we finally hear the requisite perfect authentic cadence in b. 193, given with much greater force than the previous cadence by the oboes, horns, and violas joining the strings for the tonic chord.

${ }^{69}$ Floyd Grave, "Freakish Variations on a 'Grand Cadence' Prototype in Haydn's String Quartets," Journal of Musicological Research 28, no. 2-3 (2009): 120. 


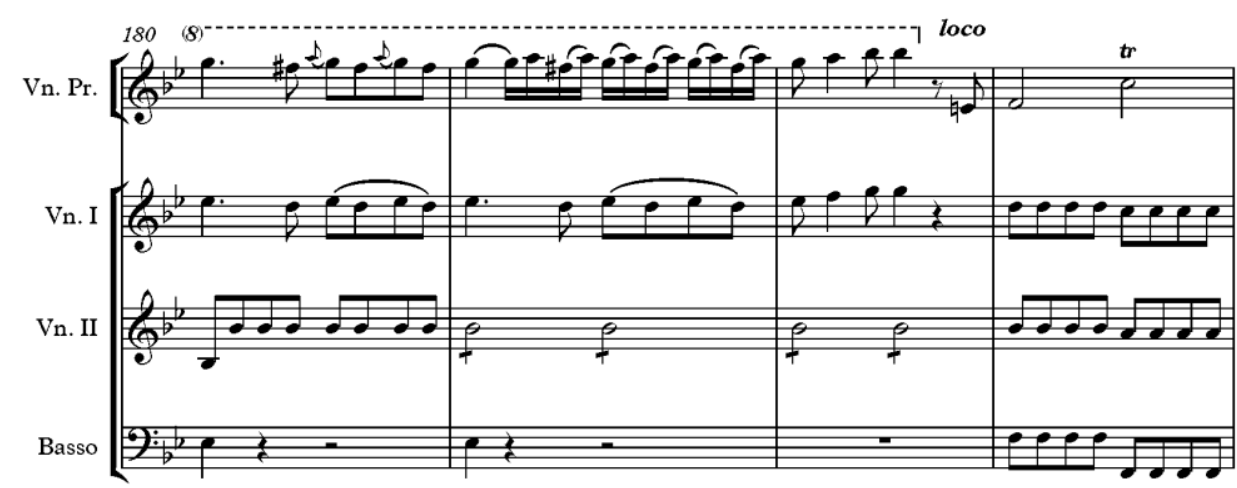

Example 1.4 Vulgar grand cadence 1

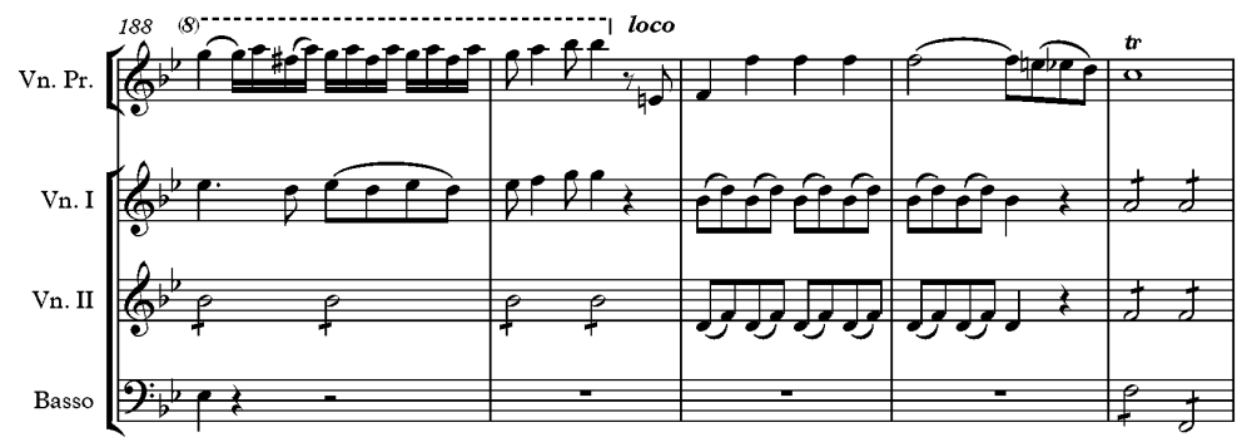

Example 1.5 Vulgar grand cadence 2

Going by Grave's criteria, these grand cadence drops within Strinasacchi's concerto appear to exceed the limits of violinistic politeness, crossing over into vulgarity. It is particularly striking that a female violinist would do this: with these compositional and performative gestures, it is almost as if Strinasacchi is communicating a bold "I couldn't care less" to potential detractors. In performing these potentially vulgar movements, Strinasacchi could be seen as actively presenting a challenge to the idea that eighteenth-century women should embody virtue, chastity, and constraint of all kinds. ${ }^{70}$

In the same article in which he explores Haydn's use of extreme grand cadences, Grave also mentions the concept of a galant pitch "ceiling" - according to Grave, Leopold Mozart puts the standard ceiling for the violin at a"'. ${ }^{71}$ Strinasacchi includes more than one passage in this concerto that centres on and even exceeds that pitch. In the Allegro this appears in the final solo episode in bb. 180-183 and again in 187190, passages which centre on g'" and also reach up to b b"' in b. 182 and 189. Grave

${ }^{70}$ Susan Moller Okin, “Rousseau's Natural Woman," The Journal of Politics 41, no. 2 (1979): 413-14.
71 Grave "Freakish Variations on a 'Grand Cadence' Prototype in Haydn's String Quartets," 123. 
argues that "to watch a violinist [ascend higher than a"'] - reaching precariously around the shoulder of the instrument with the left hand while drawing the bow carefully over a very short string-length with the right - is to gain an appreciation of the strain involved". ${ }^{72}$ The high position passages in Strinasacchi's concerto are indeed hard work for the violinist. In fact, it feels as if Strinasacchi is putting the spotlight on the concept of violin-playing as physically laborious. It requires visible effort to play accurately and with appealing tone in eighth position (with the first finger placed on $\mathrm{f}$ "' on the E string so $\mathrm{b} \mathrm{b}^{\prime \prime}$ can be reached with the fourth), due to the shortness of the string. As Grave points out, the left hand must contort around the instrument as the thumb remains anchored at the point where the neck meets the body while the rest of the hand reaches up the fingerboard. Even if I am able to make these passages sound easy, it is quite another thing to make them look easy - it is somewhat difficult to make my left hand and arm appear relaxed in these positions, mainly due to the twisting they require. These demanding passages thus challenge the centrality of the ideals of sprezzatura and stillness considered so important to eighteenth-century women's musical practices, and they also undermine the idea that women should always remain visually appealing while performing for the benefit of the male gaze. In the performance context of Strinassachi's concerto then, a"' becomes a kind of musical glass ceiling, the symbolic breaking of which has the result of defying the physical limits of women's performance and disrupting the audience's ability to comfortably employ the male gaze.

Certainly, these moments seem to intentionally draw the listener/viewer's gaze to the performer's body in action - they are the opposite of feminine stasis. The gestures feel very public: they are movements designed to be seen right at the back of a public theatre. In performing them, Strinasacchi would have also taken visible command of the physical space around her, in contrast to the very sedate and indeed almost passive movements of the (male) string players accompanying her at these moments. Strinasacchi's physical gestures also reaffirmed the public-ness of this particular concerto: the gestures are compounded by the fact that the concerto is already a public genre and that we are considering a concerto performance in a public theatre (a location which already questions the standard view of eighteenth-century European women's musicianship as domestic). The developing concept of the public

72 Ibid. 
was increasingly linked to the masculine during this period, and by dint of the perceived inherent masculinity of violin gestures, the size and boldness of these virtuosic movements come across as distinctly gendered in an eighteenth-century context. Strinasacchi could be interpreted as capitalising on her audience's perception that these virtuosic gestures were inappropriate for a woman, or indeed anyone, to perform, if we see these as physical and aural gestures so extreme as to become vulgar. Through exaggerated movement, Strinasacchi further exploits the awe inspired by the visual discord between feminine body and masculine movement: these are certainly gestures that astonish, perhaps even scandalise.

\section{Adagio}

In contrast to the Allegro, the Adagio can be seen as affirmative of femininity. It uses a number of musical features that were strongly associated with women and the feminine in the eighteenth century. These include the pastoral and related zefiro topics and the use of singing-style. These musical features, which involve small, comfortable movements and a narrow range, contribute to a gesturally contained performance style which bears relation to the physical limitations expected of women's musical performance more generally. Strinasacchi's successful performance of an unnamed adagio was directly linked to her gender by Leopold Mozart in a letter to Nannerl dated 7-9 Dec 1785. In it he wrote that:

She plays not a note without feeling, even in the orchestral ritornello she plays everything with expression, and the Adagio no one can play with more feeling and more touchingly than she. Her whole heart and soul are in the melody she is playing. Her tone remains so beautiful and so powerful. I find that overall, a woman with talent plays with more expression than men. ${ }^{73}$

As Daniel Heartz has commented, "this is an extraordinary statement coming from one of the age's finest and most experienced violin teachers, and from an era that was more likely to deprecate than praise professionalism in women." ${ }^{74}$ This is not only high praise for a women musician but high praise for any musician to receive from Leopold, indicating that he was truly impressed by Strinasacchi's abilities.

\footnotetext{
${ }^{73}$ Quoted in Daniel Heartz, Mozart, Haydn and Early Beethoven, 1781-1802 (New York: W.W. Norton, 2009), 56.

${ }^{74}$ Ibid.
} 
Breene has pointed out that in making this connection between Strinasacchi's gender and her emotive adagio playing, Leopold was drawing upon a well-worn trope of "the association between feeling and femininity —in contrast to reason and masculinity" ${ }^{75}$ The trope's very ubiquity nevertheless strengthens the idea that other audience members may well have made such a connection between Strinasacchi's femininity and her performance of this Adagio.

This movement is in $\mathrm{E}$ flat major and uses arietta form (common for middle movements of violin concertos at this time).$^{76}$ Like the first movement, it opens with an orchestral introduction (see example 2.1 below) that uses the dotted rhythms of the French overture. The whole ensemble is heard playing this in bb. 1 and 3, while in bb. 2 and 4 we hear a horn-call topic. We have already seen in relation to the Allegro that the French overture carries a structural function as a presentational topic. Horn calls can also indicate this. ${ }^{77}$ In the context of a slow second movement however, horns also signal the pastoral topic, and the presence of this topic in the Adagio is confirmed by the highlighting of the oboe and flute timbres in bb. $8-10 .^{78}$ Whether the horns indicate opening or the pastoral topic, or indeed both, they sound as if they are playing in the distance. Their interjections are frequently isolated, both in terms of the material they present and in that the strings and woodwind tend to drop out of the texture when they play. While the horns play in rhythmic unison with the strings and woodwind in bb. 1 and 3, they alone present the idiosyncratic call in bb. 2 and 4. The woodwind initially also appear to be set apart from the ensemble in bb. 8-10, but their motif is immediately echoed by the upper strings in bb. 10-12. Meanwhile in bb. 12-13 the horns present not the woodwind/string material, but their own take on the dotted rhythms contained within those phrases, making the horn motif sound like a far off afterthought. The musical "foreground" during the introduction is therefore comprised of woodwind and strings, a trend continued through the middle section of the piece where the focus is of course on the solo violin.

\footnotetext{
75 Breene, "Mozart's Violin Sonatas and the Gestures of Embodiment," 225.

${ }^{76}$ White, From Vivaldi to Viotti, 39.

${ }_{77}$ Lowe, Pleasure and Meaning, 26.

${ }^{78}$ Raymond Monelle, The Musical Topic: Hunt, Military and Pastoral (Bloomington: Indiana University Press, 2006), 5.
} 

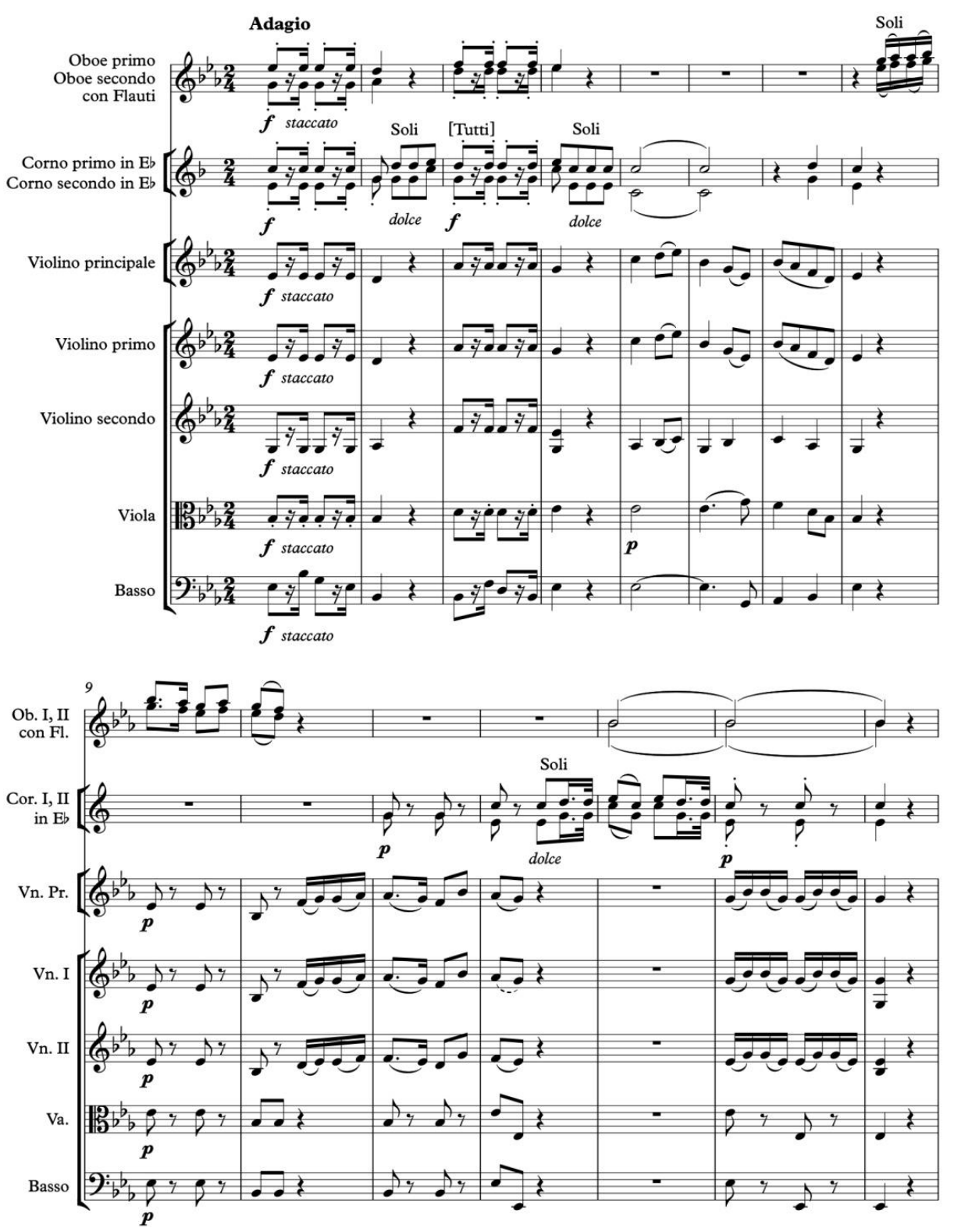

Example 2.1 Adagio introduction

Another feature of this movement that is often found in conjunction with the pastoral is the zefiro topic - a rocking or murmuring semi-quaver figure that appears in the orchestral strings, woodwind, and solo violin (see example 2.2 below). ${ }^{79}$ It is also evocative of a lullaby, a genre of song inextricably linked to the image of a mother singing to her child, an image which connotes calm, stillness, and comfort. These associations render the rocking figure affirmative of femininity. ${ }^{80}$ The pervasiveness of the zefiro topic makes comfort and compactness a veritable feature of the Adagio: these figures are easy and pleasant to play on the violin. After being

\footnotetext{
${ }^{79}$ Elaine Sisman, "Symphonies and the Public Display of Topics," in The Oxford Handbook of Topic Theory, ed. Danuta Mirka (Oxford: Oxford University Press, 2014), 100.

${ }^{80}$ Green, Music, Gender, Education, 29.
} 
heard in the woodwind in b. 8, the figure is first heard in the solo/orchestral violins in b. 10 , played in thirds. This is followed in b. 14 by a repeated major third, which can be seen as a fragmentation and thus a variation of the initial woodwind motive. As the principal violin enters with the solo part in b. 16, the orchestral violins begin a further variation on the rocking figure from b. 14. These figures are not just close and comfortable for the violinist's left hand: they work in much the same way for the bow. The most logical fingering for the first violins in bb. 14-21 is first position, with the third finger on $g^{\prime}$ (D string) and first finger on b b" (A string) simultaneously. The combination of this fingering with slurs means that the bow moves in a way that visually connotes rocking, through the constant movement between the $\mathrm{D}$ and $\mathrm{A}$ strings. Unless the second violins decided to play this passage in third position (which is plausible), the bow does not waver for the seconds - rather the fingers establish a rocking pattern on a smaller scale as they drop and lift with each semiquaver.
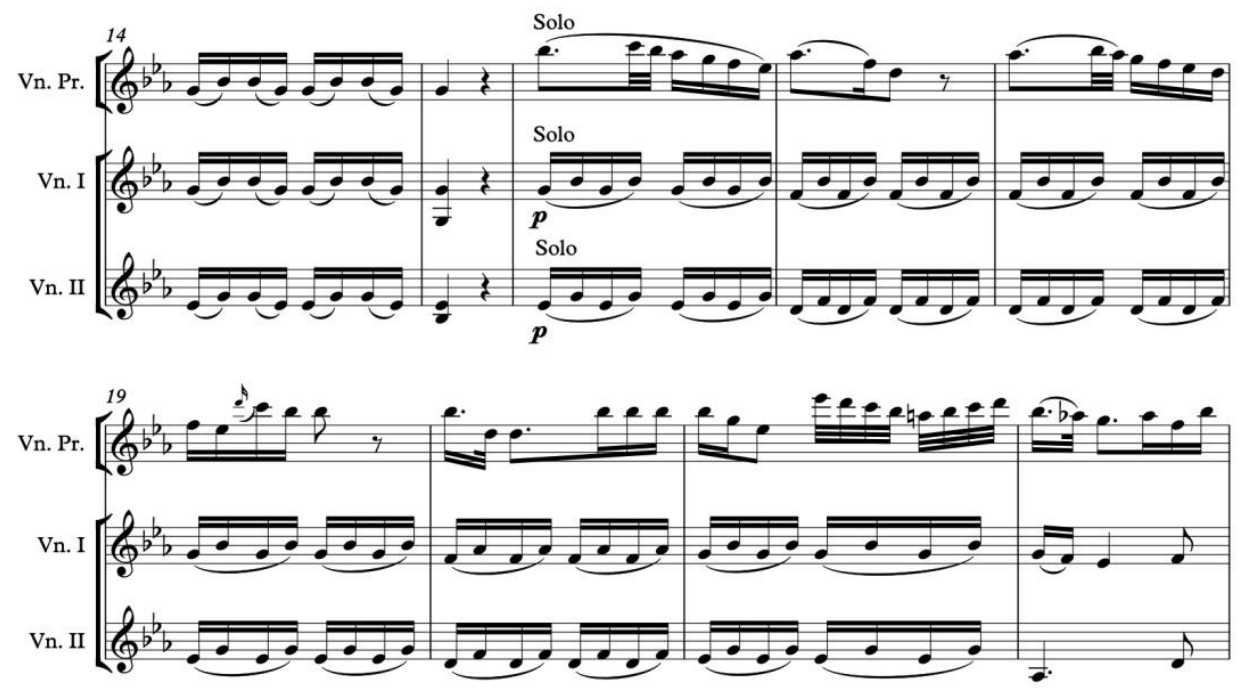

Example 2.2 Zefiro topic

Strinasacchi has taken a vocal-influenced approach to melody in the Adagio: the repetition and one-idea-after-the-other pattern followed by the Allegro (and Rondo) are replaced by long lines that foreground melody. This signals that singing style dominates this movement, foregrounding the second type of virtuosity. Though the pastoral encompassed a wide range of meanings in the eighteenth century, performing music that utilised the pastoral and singing style was commensurate with eighteenth-century tropes surrounding femininity, specifically through the link made 
in pastoral-themed works between femininity, nature, and sexual subservience. ${ }^{81}$ It is important to note, however, that these topics are commonly found in second movements, so I emphasise that it is their performance by a female violinist (rather than their presence an abstract score) that brings out issues of gender in this movement. Indicators of singing style outlined by Sarah Day-O'Connell (drawing on Ratner, Monelle, and various eighteenth-century theorists) include features common to vocal melodies, such as narrow range and stepwise movement. ${ }^{82}$ Others relate to vocal performance practice, and include "vibrato, messa di voce, legato... and rubato." 83 Most signifiers in this second group are not indicated by the score, though Strinasacchi may certainly have used these techniques in performance. Legato lines, however, are clearly indicated by the preponderance of long slurs in this movement (which contrasts with the outer two). On top of this, the form of the movement clearly takes inspiration from vocal practice. ${ }^{84}$ When combined with the adagio tempo, a narrow range, stepwise movement, and legato articulation, this creates a lyrical solo violin part that follows vocal genre conventions and is indeed "singable."

There are a number of indications that Strinasacchi's performance of singing style may have emphasised the idea that she was affirming her femininity through playing this Adagio. Singing, as discussed in Chapter One, was an activity which was strongly coded feminine. ${ }^{85}$ This correlation went further: there was not only a connection between femininity and the act of singing, but with the use of singing style as a topic in non-vocal music. ${ }^{86}$ Expressivity in instrumental performance was intrinsically linked to emulating the singing voice in the eighteenth century, and in fact no instrument was felt to be closer to reaching this ideal than the violin, due to similarities in timbre, register, and versatility. Francesco Geminiani, for instance, said that "the Art of playing the Violin consists in giving that Instrument a Tone that shall in a Manner rival the most perfect human Voice" ${ }^{87}$ Recalling Leopold Mozart's comments about Strinasacchi's adagio playing, we remember that he went so far as to say that expressivity was the prerogative of talented women musicians, more so than

${ }^{81}$ Leslie Ritchie, Women Writing Music in Late Eighteenth-Century England: Social Harmony in Literature and Performance (Burlington; Aldershot: Ashgate, 2008), 133-136.

82 Sarah Day-O'Connell, "The Singing Style," in The Oxford Handbook of Topic Theory, ed. Danuta Mirka

(Oxford: Oxford University Press, 2014), 238-258.

83 Ibid., 248

84 White, From Vivaldi to Viotti, 39.

${ }^{85}$ Green, Music, Gender, Education, 28-30.

${ }^{86}$ Day-O’Connell, “The Singing Style," 254.

${ }^{87}$ Francesco Geminiani, The Art of Playing on the Violin, 1751, ed. David D. Boyden (London; New York: Oxford University Press, 1951), 1. 
male ones. Due to the link between emulating the voice and expressivity in violinplaying in particular, and the connection of vocal performance and expressivity with femininity, it seems possible that performing singing-style melodies and other features drawn from vocal practice might have been perceived by Strinasacchi's audience as an act that was consonant with her gender. ${ }^{88}$

The idea that this Adagio displayed a performance of femininity is bolstered by physical gestures. Narrow range and stepwise movement are features of singing style that are visually perceptible by a listener/viewer, and tie in not only with the feminine associations of singing, but with the feminine associations of certain kinds of keyboard performance - specifically, physically contained keyboard performance. While the range spanned by the solo violin in the Allegro and Rondo exceeds three octaves (from $\mathrm{g}$ to $\mathrm{b} \mathrm{b}^{\prime \prime}$ in the Allegro, and $\mathrm{g}$ to $\mathrm{c}^{\prime \prime \prime}$ in the Rondo), the Adagio does not venture above $\mathrm{f}$ "'. The solo violin range in this movement thus not only reflects that of the female singing voice, but perhaps suggests a violin-playing femininity that echoes the physical constraints well-established within in the context of eighteenthcentury domestic women's keyboard music (see example 2.3 below). The kinds of physical gestures produced in the course of performing singing-style virtuosity also contrast noticeably with those produced when performing in the brilliant style. The use of stepwise movement and ornamentation which "fills in" leaps in the Adagio by contrast closely resembles that of contemporary vocal arias. This is particularly the case with the use of passaggi (b. 16, 25, 31, 32) and "skipping" appoggiaturas (b. 25, 26). The stepwise movement of the solo violin line creates a visually (and, for the performer, physically) appealing left hand. The upwards run in b. 25 of the Adagio looks and feels mellifluous as the fingers drop quickly onto the fingerboard. Though this left hand movement looks somewhat similar to the "hammering" virtuosic gestures discussed in relation to the Allegro, the combined impact of left hand and bow can change the affect of this gesture. In this moment, the bow creates a long, smooth gesture due to the slur. Furthermore, the fingers do not have to strike the fingerboard to the same degree as in loud passages. This is also the case for bb. 31 and 32 , though the hand must reset at the beginning of each run due to the addition of $d b^{\prime \prime}$.

\footnotetext{
${ }^{88}$ For more on vocality and the violin, see Maiko Kawabata, "Violinists 'Singing': Paganini, Operatic Voices, and Virtuosity," Ad Parnassum: A Journal of Eigbteenth-and Nineteenth-Century Instrumental Music 5, no. 9 (2007): 7-39.
} 
The "graces" in bb. 25-27 and bb. 31-31 also add visual grace. The fingers of the left hand appear to dance or skip down the fingerboard as they release the short, onthe-beat appoggiaturas of b. 25 in time for the main note. This is a far cry from the laborious and larger-than-life leaps of the Allegro (bb. 55, 76, and 182) and Rondo (bb. 71, 73, and 97-99). Though there are plenty of runs and segments of stepwise movement in the solo violin, these movements include far more arpeggiation and smaller leaps than the Adagio. That such visible charm and grace could be considered feminine even when played on the violin is supported by the review of Madame Guilberg discussed in Chapter Two. Strinasacchi's own playing was at times said to be "tender" or "sensitive" (zart) and "recited with delicacy" (mit Delikatesse vortrug), indicating that such an interpretation of these physical movements in her Adagio is consistent with contemporary opinions. ${ }^{89}$
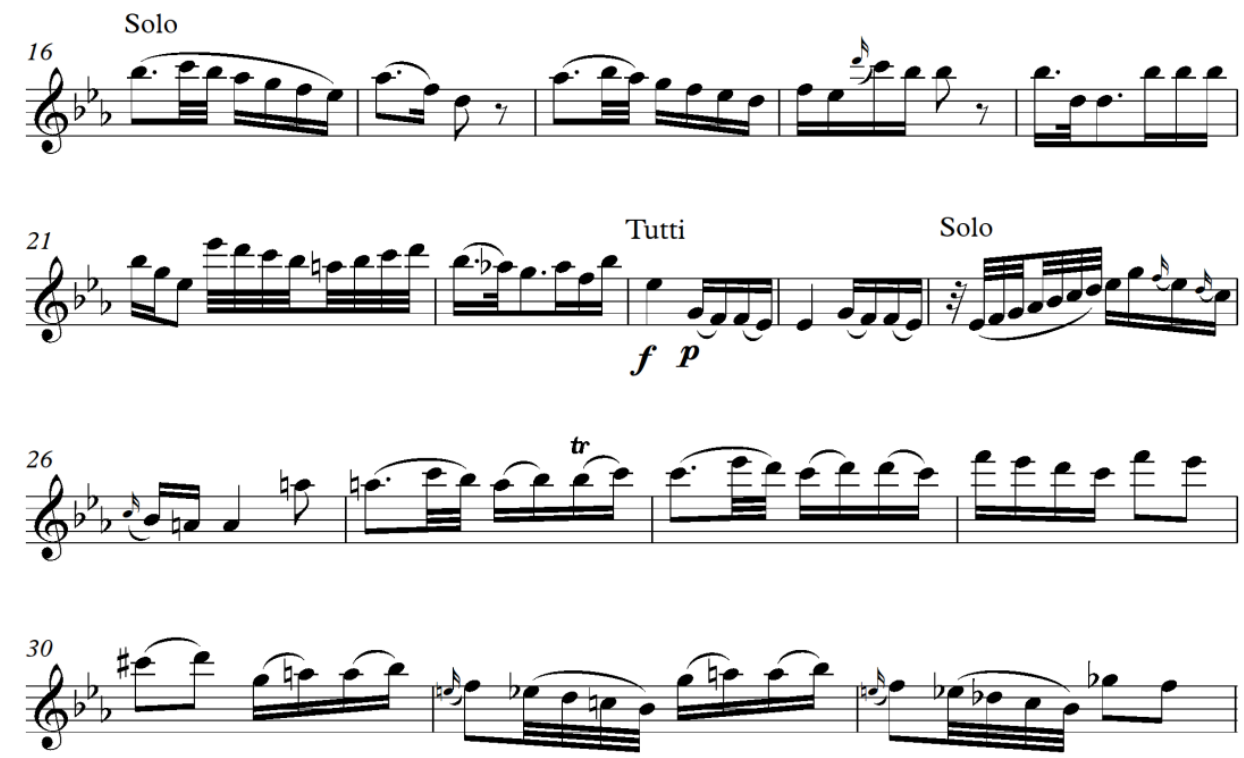

Example 2.3 Vocal-influenced melody

Towards the end of the movement (in bb. 47-54) the solo violin's first phrase from bb. 16-23 returns. Though the repetition signals arietta form, the order of the repeated phrases here is perhaps slightly unusual: the form becomes almost like a palindrome in that the solo violin's first phrase comes after the middle section solo, followed by the second phrase of the orchestral introduction, essentially reversing their order. Horns can signal closure as well as opening: that this phrase is repeated suggests the topic's closing function, but the horn timbre here also serves to

${ }^{89}$ Cramer's Magazin der Musik 1784, 346; Abend-Zeitung, 2 November 1805. Quoted in Timmermann, "Strinasacchi, Regina". 
underscore this function. ${ }^{90}$ In any case, their return reminds us of their background presence and also provides an amusing link to the Rondo, where a sudden transition from calm pastoral, singing style, and zefiro topics to the lively chasse topic of the rondo refrain occurs.

\section{Rondo Affectuoso}

Though both the Allegro and Rondo affectuoso [sic] contain play between differently-gendered elements, the Rondo is a particularly ambiguous and changeable mixture. There is a marked sense of disruption in the move from the pastoral Adagio to the chasse-dominated Rondo - the entrance of the "horn" (solo violin) suggests that the far-off hunting party has unexpectedly crashed straight through the peaceful glade in which we were reclining mere moments before. In the Rondo itself, there is an interesting tension generated by the juxtaposition of rondo form (gendered feminine) and the chasse topic (gendered masculine). The rondo refrain acts as a frame that contains the wildness of the solo episodes, rendered Other by their virtuosity and occasional use of the minor mode. This aspect of containment (and the multiple gendered layers found in the refrain), led as it is by the solo violin, is made all the more interesting by the fact that the female violinist is both leader of the containing hunt refrain and the proponent of the virtuosic contained-Other material. Vulgarity is at its most extreme in the second and third solo episodes of this movement, particularly in the minore section (which contains some of the most visually laborious leaps) and in the third solo which contains the highest and most extended moment of passagework in the concerto.

Before exploring this in detail, it is worth noting that the movement's title is in itself a point of interest, as the paring of "rondo" with "affettuoso" was a highly unusual choice. It was far more common for slow movements to be in affettuoso style: the term translates to "affectionate" or "loving" in English (a sentiment commensurate with slow movements) and was further associated with "gentleness, ardour, tenderness, flattery... heartwarmingness." 91 This suggests that the Rondo

\footnotetext{
${ }^{90}$ Lowe, Pleasure and Meaning, 26.

${ }^{91}$ David Fallows, “Affettuoso," Grove Music Online, Oxford Music Online, Oxford University Press, accessed 6 February 2016,
} 
should not be performed in too boisterous a manner. According to David Fallows, "affettuoso" also has a second, more intriguing definition: it can denote an "affectconscious style of performance..."92 The affettuoso marking also indicates that the performer should be hyper-aware of the different affects conjured by the array of topics found in the Rondo. Fallows' second definition also implies that an element of artificially or exaggeration is present in the affettuoso style. In the context of Strinasacchi's concerto - where the performer's body and the concept of display are foregrounded - it is tempting to read the affettuoso marking as an indication that the Rondo is a kind of performance about performance. An exercise in display in which display itself is a feature. Whether or not this was Strinasacchi's intention (which is perhaps doubtful) the affettuoso qualification draws our attention to the great emotional and topical variety of this Rondo. ${ }^{93}$

The Rondo begins with the solo violin launching into a rollicking chasse- or hunt-themed, period-structure refrain (see example 3.1 below). The gestures of the first two notes are visually similar to those that open the Allegro: a short anacrusis on an up bow followed by a longer downbeat on a down bow. Here however (in keeping with the "low" style of last movements) the effect is aurally and visually much less grand, as the soloist is the only instrument that plays both the anacrusis and the downbeat. ${ }^{94}$ In the antecedent segment (bb. 1-8) the solo violin has the melody and here imitates a horn through its use of repeated notes and hornappropriate intervals. In stark comparison to the Adagio, the bow of the soloist appears to visibly "escape" the string, bouncing in the lower half and imparting energy to each quaver. Control by the right arm is of course still required so that the bow does not become wild, but it is a very different kind of control to that needed for long slurs. The whole ensemble participates in the even more boisterousness consequent phrase (bb. 9-16), helping to confirm that the Adagio atmosphere has been roundly dismissed. Thus, musical stillness, visual stillness, and the feminineaffirmative atmosphere stillness connotes are disrupted.

This disruption was perhaps all the more rude (or fun, depending on your point of view) to the ears of an eighteenth-century audience as this kind of imitation -

http://www.oxfordmusiconline.com/subscriber/article/grove/music/00258; David Lasocki, "Quantz and the Passions: Theory and Practice," Early Music 6, no. 4 (1978): 567 n24.

${ }^{92}$ Fallows, "Affettuoso".

${ }^{93} \mathrm{My}$ thanks to Erin Helyard for drawing my attention to the unusualness of the affettuoso marking.

${ }^{94}$ Lowe, Pleasure and Meaning, 68. 
violin emulating horn - was considered crass by many theorists. ${ }^{95}$ In terms of the gendered associations of musical material, we have moved suddenly from material encoded feminine and which is relatively passive physically, to material which is aurally and visually dynamic, and topically encoded masculine. According to Raymond Monelle, the chasse topic not only evoked connotations of "manliness and nobility," but other ideas associated with these concepts, such as "adventure, risk, and exhilaration; youth, the overcoming of danger". ${ }^{96}$ The chasse is indicated here by a number of features, the most obvious of which is the $6 / 8$ metre. Repeated notes, triadic figures, and regular periodicity are other markers found in the refrain, but the use of double-stopped thirds (imitating horns bicinia) in bb. $42-48$ and bb. 135-150 (in solo episodes one and three) also indicates the presence of the chasse outside of the refrain. ${ }^{97} \mathrm{~A}$ less obvious indicator of the hunt is that the movement is in the "oldfashioned" hunting key of B flat major (used in violin works by Vivaldi, such as his Concerto No. 10 La caccia) though by the late eighteenth century it was more standard to use D major (in France) or E flat major (in Germany). ${ }^{98}$

Including a finale that used the chasse topic was a popular way to end a symphony or concerto during the 1770 s and 80 s, and chasse movements also quite frequently appeared in violin showpieces and in keyboard suites. ${ }^{99}$ Women thus frequently performed works utilising the chasse and other masculine topics, such as the march, in the keyboard suite and sonata genres. There is, however, a key difference between the appearance of the chasse topic in this context and in the context of the public concerto, and that lies in the level of containment encoded in each genre. Keyboard suites, which involve short movements often characterised as trivial, were a domestic genre. Though the use of such topics in these pieces for women arguably allows the player to metaphorically explore eighteenth-century masculine modes of behaviour embodied by the chasse topic - running, the outdoors, danger, thrill (experiences that were restricted for middle- and upper-class women) - they do so within the sanitised safety of the drawing room. The freedom implied by the topic remains contained and only expressed privately. So while the chasse rondo finale was almost ubiquitous in a number of genres, when this topic is

${ }^{55}$ Ritchie, Women Writing Music in Late Eighteenth-Century England, 140.

96 Monelle, The Musical Topic, 95.

${ }^{97}$ Ibid., 90, 99-100, 98.

${ }^{98}$ Alexander L. Ringer, "The 'Chasse' as a Musical Topic of the 18th Century," Journal of the American Musicological Society 6, no. 2 (1953): 154; Monelle, The Musical Topic, 42.

${ }_{99}$ The Musical Topic, 85-90. 
taken out of the home and into the concert-hall via the concerto, the constraints found in domestic keyboard music evaporate, and a woman performing the topic becomes potentially transgressive.

Crucially, Strinasacchi's instigation of this musical hunt positions her as its leader. The solo violin monopolises the chasse signifiers - repeated notes and bicinia movement - when there are actual horns available. The solo violin's domination of the chasse features, even when orchestral horns could have been used, reinforces the female violinist's active (masculine) involvement as leader of the hunt. This is a position which contrasts noticeably with the passive spectator role played by women in actual eighteenth-century hunts: they usually either watched from the safety of a carriage or met the hunters for a meal before or after the fact. ${ }^{100}$

${ }^{100}$ See Watteau's Le rendez-voud de chasse (c.1717-18) 

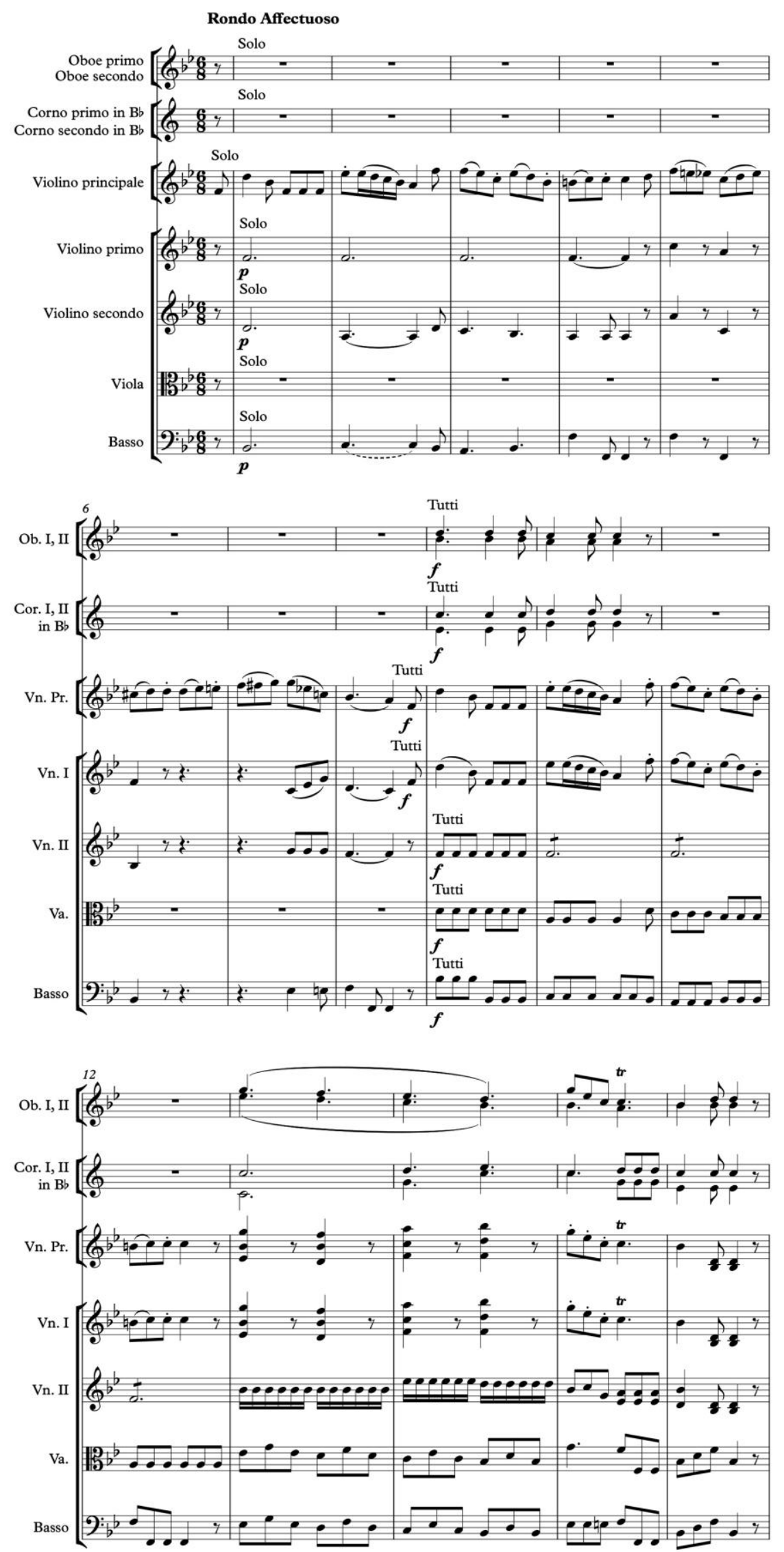

Example 3.1 Refrain 
Along with being a decidedly male affair, hunting was also the prerogative of royalty and the aristocracy. Consequently, though the chasse topic is vigorous it is not unrefined and (as Monelle indicates) its presence has distinct class associations. Extreme, bold, or otherwise unrestrained or "impolite" sounds and gestures are thus not found in the chasse refrain. Instead these occur in the solo episodes, particularly the second and third, meaning they often act as foils to the refrain's "norm." The first episode is virtuosic, but it is not as extreme as the others: it only ascends to $\mathrm{f}$ "', contains only one leap, and uses the chasse topic, marking it as relatively normative next to the other episodes. The second episode, meanwhile, presents a stark contrast to the cheery refrain. The transition from the refrain to the minore section in b. 82 is much more abrupt than that between the refrain and the first episode. This is the result of the concurrent switch from chasse topic in the tonic to entirely new material in the relative minor of $G$ minor.

This new melody is laden with neighbour notes, quick ornaments (b. 82 in the solo and b. 92 in the orchestral violins), and figures which feature "hopping" between two notes (bb. 84, 86-89, and 91 - see example 3.2 below). In conjunction with the minor mode, these features could indicate the presence of an "exotic" topic such as the Turkish or Hungarian topics found in much eighteenth-century music. Whether this ornamented melody does or does not utilise a Turkish or Hungarian topic, the contrast between the new material and the chasse refrain certainly serve to render the former very "Other" by comparison. ${ }^{101}$ This Otherness is reinforced by the diminished seventh leaps found in bb. 87 and 89, as the angularity of these leaps forms a noticeable contrast with the straightforward diatonic steps and skips of the refrain. This is also a moment where the aural and visual seem almost at odds with one another: though the leap sounds strange in the context of this Rondo, it does not look this way. Instead, the move from the $\mathrm{D}$ to the A string and back again in one bow is an easy and indeed graceful movement for the soloist, and the $\mathrm{f} \#$ ' and $\mathrm{e} b$ " can comfortably be accommodated by the left hand in first position. The discord between sight and sound here perhaps augments the strangeness of this interval in comparison to the rondo refrain, because our ear expects it not only to sound but to concurrently look odd. The minor-mode material is immediately followed by a brief foray into the pastoral (bb. 98-97), indicated by tonic drones in the bass and second

101 Catherine Mayes, "Turkish and Hungarian-Gypsy Styles," in The Oxford Handbook of Topic Theory, ed. Danuta Mirka (Oxford: Oxford University Press, 2014), 213-215. 
violins and a simple melody in the solo (doubled an eleventh below by the first violins) that keeps within the comparatively narrow range of a sixth.
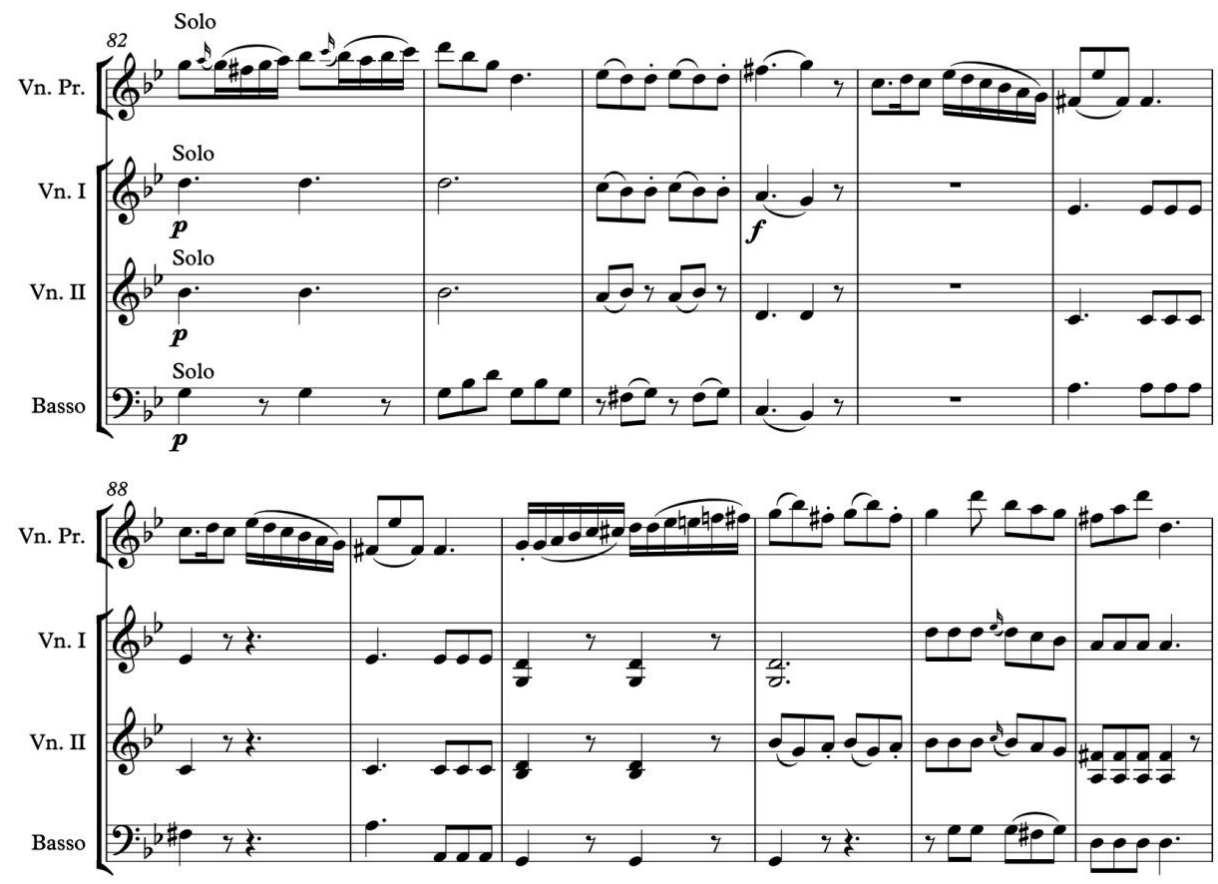

Example 3.2 Minore section opening

After presenting a jovial melody in bb. 98-104 followed by whirling semiquaver figures, we suddenly swerve back into $G$ minor again in b. 112 (see example 3.3). The tonality of bb. 112-118 and the large leaps found in bb. 113-115 allude to the diminished sevenths heard at the opening of the minore. The leaps in bb. 113-115 get increasingly larger, and the fact that the accompaniment drops out entirely here puts the focus all the more completely on the solo violinist's physical virtuosity. Though this passage is not at all as challenging for the left hand as many of the others in this concerto (the lower note is open $\mathrm{g}$, meaning that the left hand does not have to shift up and down), this is one of the most physically involved moments for the bow arm in the whole piece. The violinist must repeatedly dive from a slightly longer down bow on the A or $E$ string to a quicker up bow on the $G$ and then back again, creating large circles in the bow arm elbow as it moves backwards and forwards between the strings. 

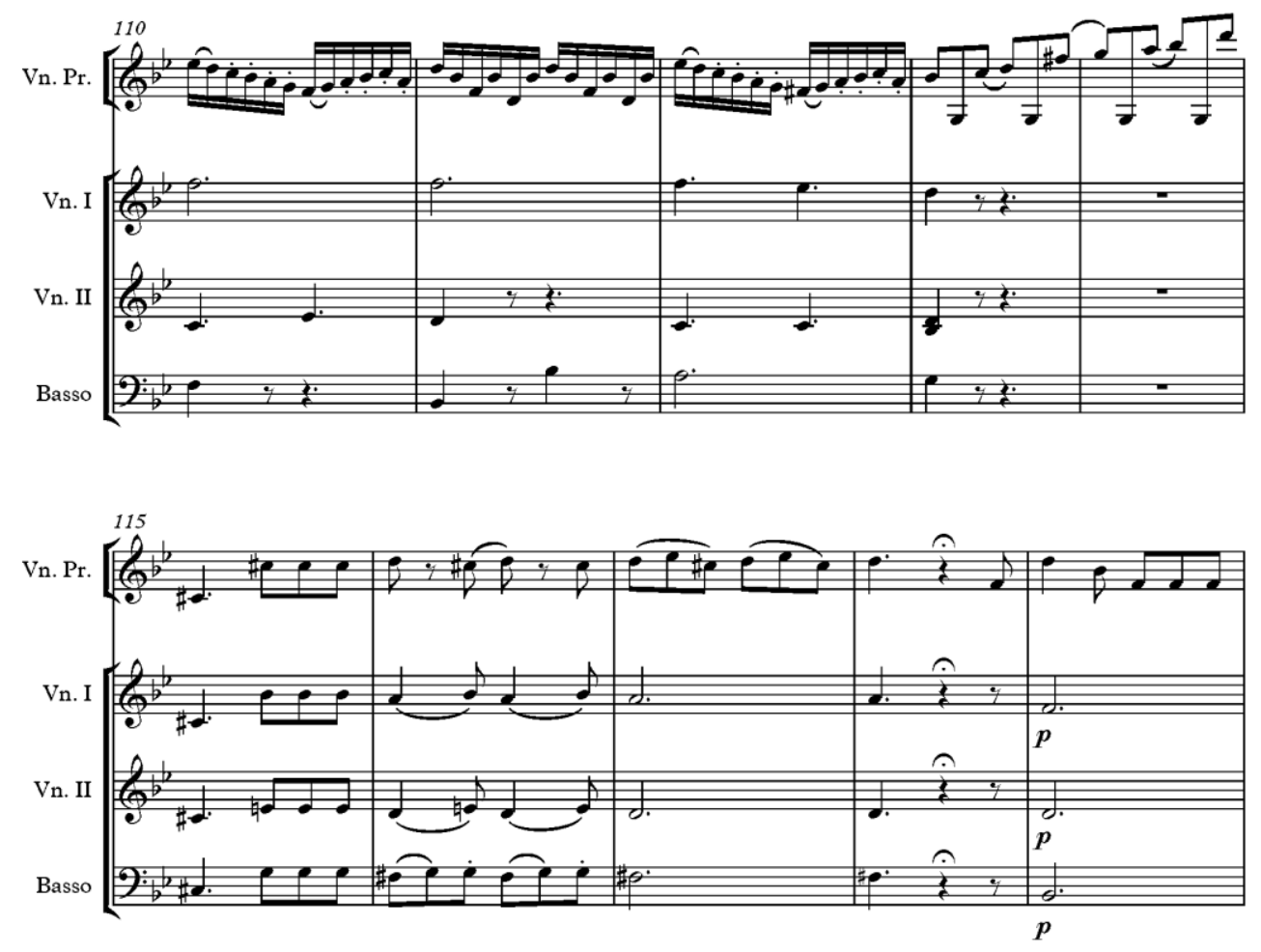

Example 3.3 End of minore section

The third episode opens with a continuation of the chasse topic with yet more imitation of horns in the solo violin that persists until b. 150. The horns' presence as topical indicators of opening and stability seem almost an attempt to apologise for the excesses of the second solo episode. However, the highest point of the whole concerto in terms of pitch occurs in the next passage, bb. 150-157, a passage which from b. 154 reaches up to a"' but climbs to c'"' in b. 157 (see example 3.4 below). Seventh position is required for the quaver and semi-quaver figures, so the fourth finger must extend upwards to reach c'"'. As discussed in the Allegro, high positions involve visible contortion of the left arm and hand. The effort looks all the more impressive (and uncomfortable) here because the violinist is required to stay in seventh position for so long (eight bars). This is followed by a plunge down to a for two bars of ascending arpeggios, and three bars of dainty stepwise quavers, the straightforwardness of which seem to possess a teasing quality after such extreme gestures. In bb. 165-174 we hear another vulgar grand cadence (again in the dominant), though this example contains certain alterations. Rather than one drop, we are treated to two - decorum has been violated twice over. The first ascent and drop occur in bb. 165-166 (a"' to a) followed by the second in bb. 167-168 (b b"' to 
b). The outrageousness of the two drops is counterbalanced by a variation on the dainty quavers of bb. 160-162 between the second drop and the cadential trill. This and the transitional material of bb. 174-178 appear to be attempts to sublimate the virtuosity of the final solo episode: all movement in the solo violin is now either by step or small skip, tidying the material of the last episode away in order to move smoothly into the final iteration of the refrain.
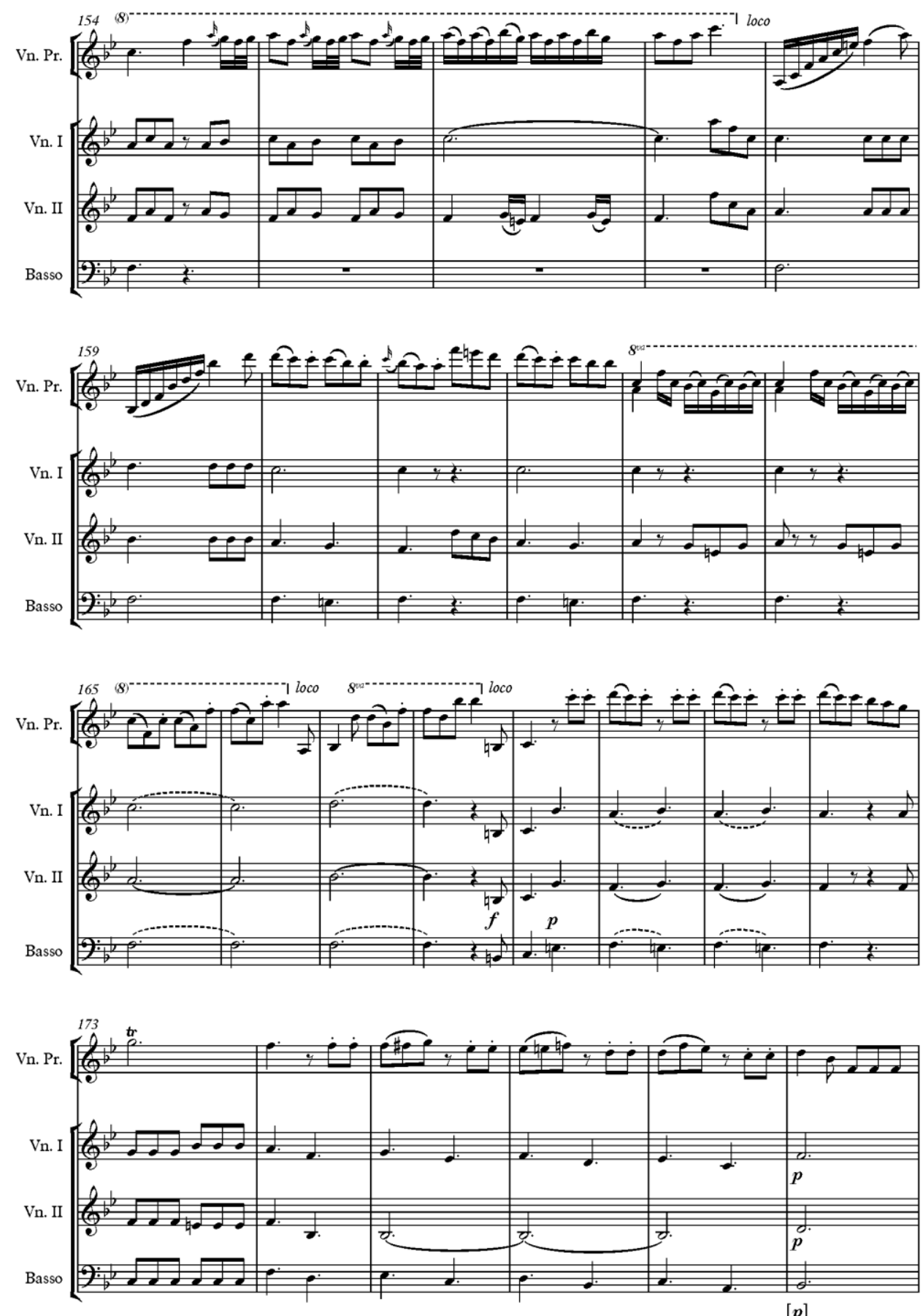

$[p]$

Example 3.4 High points of the Rondo 
The contrast in gesture, topic, and level of virtuosity between the refrain and solo episodes (particularly the second), along with the transitional passages which appear to "tidy up" the virtuosic content of the episodes before the return, suggest that the rondo form serves not only to frame but to contain the excesses of the solo episodes. The chasse refrain, embodying the masculine and noble eighteenth-century norm, seeks to tame the sometimes vulgar and transgressive Other embodied by the solo episodes. The second episode in particular represents the Other, as it does not hold any hints of the chasse topic. The minor-mode sections of the second and brilliant-style sections of the third episodes also visually strain against the limitations set out by the refrain. In the refrain, though the bowing pattern used for the quavers (two slurred followed by a separate up bow) creates lively bow action, and the chords in bb. 13-14 require bow strength, these movements do not come close in size and virtuosity to the many diving bow gestures created by leaps in the solo episodes. Furthermore, in the refrain, the left hand does not once need to move outside of first position, while the highest note and longest passage in a high position in the whole concerto occur in the third episode.

The containment function of the refrain and its gendering as masculine is particularly interesting when one considers that, according to Head, north German theorists understood the rondo to be a distinctly feminine genre. This is because of its French origins (French courtly life being perceived by the Germans as highly feminised in a negative sense), and the genre's "circularity of form.". that the repetitive nature of rondos creates harmonic stasis, and that the nonprogressive nature of the structure bears similarity to the non-progressive approach to female education espoused by, among others, Rousseau. ${ }^{103}$ The juxtaposition of these two distinctly gendered musical concepts (rondo form and the chasse topic), though in itself not usual, is thrown into stark relief by the gender of the composer and original performer. These codes, which under "normal" circumstances (composition and performance by a male violinist) are unremarkable, are brought to the fore when performed by a marked (female-gendered) body in a professional and public context.

There is perhaps a sense of tension inherent in the combination of masculine/active chasse and feminine/passive rondo - while the refrain is vivacious,

102 Head, "Like Beauty Spots on the Face of a Man," 159.

103 Ibid., 159-161. 
the very nature of rondo form means that we keep circling back to the same refrain, the result being that the movement does not "go" anywhere. This tension also exists in the physical gestures of the refrain: they are concurrently forward-driving and circular. The notes of the refrain require a boisterous bow (the eager bouncing noted earlier) and fleet left hand fingers which seem to hurtle forwards, but these same movements also echo the roundness of the rondo form. In playing this, my bow hand and lower arm literally make small circular movements in the lower half as I perform small retakes in order to remain in this part of the bow (necessary for keeping short notes under control at speed). These quick round bow movements are also "repetitive" in that they are repeated many times within each of the two halves of the refrain, and in that the period structure of the refrain means that bb. 1-4 are literally repeated. Hence gestural and aural circularity are emphasised simultaneously along with forward-driving activity. It is interesting to consider that it is the physical/visual and "superficial" feature (the chasse) that is considered masculine, and that the "deep" abstract/intellectual feature (rondo form) is considered feminine here. The containment of the solo episodes affected by the refrain and rondo form is thus not a straightforward situation of the unruly Other being sublimated by the masculinised norm. This complication is underscored by the fact that the solo violin plays all of this material - she instigates both the refrain and the solo episodes. We might therefore think of the use of sometimes conflictingly gendered musical features in the Rondo as an exploration of different gender roles by the eighteenthcentury female violinist.

Strinasacchi's concerto enables the female violinist to explore a variety of gendered roles through violin performance. Musically and metaphorically, she plays the virtuosic acrobat, operatic singer, exoticised Other, and leader of the hunt. Literally, she fulfils the role of soloist, integrated orchestral member, and orchestra leader. She achieves this through both musical material and the performance gestures that material creates. As such, she physically appears to embody a number of differently-gendered roles, some of which "match" the visible gender of her body 
(expressed through indicators such as dress) and others of which do not, resulting in a work that presents the female violinist as a delightfully multifaceted figure. ${ }^{104}$

${ }^{104}$ See Cusick, "Performing/Composing/Woman." 


\section{Conclusion}

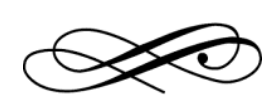

In looking at the physical gestures created by different musical material in Strinasacchi's violin concerto, it is apparent that some of these unquestionably disrupt the male gaze, while others stage much less jarring interruptions. For commentators who voiced displeasure at the sight of female violinists performing, it seems that any violin gestures were seen as disruptive - they interfered with the ability of these listener/viewers to consume the female performer as object - and were thus frequently characterised as masculine movements. For others, however, a woman violinist who embodied masculine playing styles (for instance through displaying power and force of tone) was a successful musician, showing that some equated successful violin-playing with manliness, and that this was not always offlimits for women.

For yet other commentators (though they were in the minority), violin-playing was apparently neither disruptive to the gaze nor considered incommensurate with femininity. Though these writers tended not to comment specifically on movement or gesture, the descriptions they used (for instance, "charming" or "delicate") match with musical features (such as stepwise movement, legato bowing) which create contained, sprezzatura gestures. These physical movements fit comparatively well with the vocabulary of small and constrained movements deemed to be the ideal in established forms of women's instrumental performance on feminine instruments. It is of course possible that commentators who did not talk of disruption saw women's musical performance as something that didn't have to please the male gaze. The presence of remarks regarding musically-irrelevant elements of women violinists' appearance (such as their figure or physical beauty) would seem to indicate that this was not necessarily the case. It thus appears that the male gaze was an important aspect in the reception of women's violin performance, but that the instrument and the gestures required to play it were not always seen as at odds with the ability of audience members to experience visual pleasure.

In contrast, other kinds of gestures in this concerto (including vertiginous leaps, contorted high passagework, and large movements of the bow) seem almost to 
exceed boundaries of politeness surrounding men's violin performance, let alone a style of performance affirmative of a woman musician's femininity. We could speculate about Strinasacchi's motivations for making such gestures a veritable feature of the outer movements. One possibility is that inspiring awe and excitement through pushing virtuosic boundaries was simply part of the culture in which she worked as a touring soloist - it was a form of emulating the (male) violinists around her. This was necessary in the competitive world of attracting a paying audience. A second reason might be that this was what Strinasacchi had learnt to do (as a violinist and possibly a composer) at the Pietà: impressive soloistic display was integral to women's performance there. It was such a feature because it was through impressive performance specifically by women instrumentalists and vocalists that the institution supported itself financially: exploiting the novelty of women musicians of all kinds being able to perform impressive musical feats was a specific attraction of the ospedali concerts. ${ }^{1}$ Strinasacchi's use of such eye-catching features might therefore have been an instance of her putting her experience of ospedale methods to use, capitalising on the visual discord between her visible gender and physical movements in order to get audiences talking about her performance style, thereby selling more tickets.

The variety of gendered roles explored in Strinasacchi's concerto thus in some ways reflects the diversity of responses to female violinists in reality: in performance, listener/viewers perceived some women as performing masculinity, others femininity, and yet others imply that female violinists enacted a mixture between the two poles. A number of accounts suggest that some performers appeared to simultaneously embody differently-gendered traits, and this mixture could be perceived as harmonious. Johann Friedrich Reichardt, speaking of a Berlin performance by Crux in 1792 remarked: "so wholly sweet and nobly feminine is her performance in quiet and touching pieces, so powerful, sure and accomplished is her performance in lively movements."2 A review from Cramer's Magazin der Musik in 1783 meanwhile said this of Strinasacchi:

It is unbelievable with how much ease and grace this girl (she is around 18 years old and very well trained) shows how to handle this difficult instrument. The tone that she pulls out of

1 Tonelli, "Women and Music in the Venetian Ospedali," 68-76.

${ }^{2}$ My translation: "So ganz zart und edel weiblich ihr Vortrag in rührenden und angenehmen Stücken ist, so kräftig, sicher und vollendet ist ihr Vortrag in lebhaften Sätzen.” Timmermann, "Crux, Marianne". 
her Cremonese violin is finely polished and silvery. She played the violin concertos of

Giarnowick, St. George, Borra, Cambini etc. especially well, and with a lot of fire. ${ }^{3}$

Both of these reviews reconcile the idea that female violinists could convey both masculinity ("powerful," "with a lot of fire") and femininity ("sweet and nobly feminine" and "finely polished and silvery [tone]") with violin performance. While such reviewers may have registered surprise or felt it to be unusual, they do not indicate that embodying both masculinity and femininity was necessarily contradictory. By showing that violin performance could be commensurate with both eighteenth-century ideas of masculinity and femininity, Strinasacchi's concerto attests to the fact that women could and did play the violin to a virtuoso level. Furthermore it shows that women could successfully assume roles that were equated with masculine authority.

It also suggests that comparisons could be drawn between women's violinplaying and the performance of travesty roles. Through violin-playing, these women physically embodied a visibly masculine "role," projected a "voice" that was ambiguously gendered (associated with sopranos but also castrati, thus with fading authoritarian power), and were marvelled at for their ability to masquerade as man. ${ }^{4}$ Further research, particularly into the gendering of the appearance and sound of the violin prior to c.1816 (thus using Kawabata and Hoffmann as a point of departure) would be required, but this line of enquiry could produce interesting findings.

This provides a more nuanced view both of violin performance and of women's musical performance during the eighteenth century. It also hints at the liberating potential the traditionally male instrument may have had for these women, and would to some extent go on to have for a much larger number during the late nineteenth century. ${ }^{5}$ The Bluestocking Hester Lynch Piozzi in fact indicates that some saw proto-feminist parallels between violin-playing and expansion of women's rights during the late eighteenth century. In a diary entry from May 1789, Piozzi remarked: 'How the Women do shine of late! ... Madame Krumpholz' [sic.] Tasteful

\footnotetext{
${ }^{3}$ My translation: "Es ist unglaublich, mit welcher Leichtigkeit und gutem Anstand das Mädchen (sie ist ohngefähr 18 Jahre alt und sehr gut gebildet) dies an sich schwere Instrument zu behandeln weis. Der Ton, den sie aus ihrer cremonesischen Geige herauszieht, ist feiner abgeschliffener Silberton. Die Violinconcerte von Giarnowick, St. George, Borra, Cambini etc. spielt sie besonders gut, mit vielem Feuer." "Strinasacchi, Regina".

${ }^{4}$ Naomi André, Voicing Gender: Castrati, Travesti, and the Second Woman in Early-Nineteenth-Century Italian Opera (Bloomington, IN: Indiana University Press, 2006), 3-4, 9.

${ }^{5}$ Gillett, Musical Women in England, 79.
} 
Performance on the Harp, Madame Gautherot's wonderful Execution on the Fiddle; - but say the Critics a Violin is not an Instrument for Ladies to manage, very likely! I remember when they said the same Thing of a Pen." ${ }^{36}$ Here Piozzi likens the view of violin-playing as a man's activity to similar responses to eighteenth-century female authors, indicating that she sees such views as ridiculous and - like negative opinions about women and authorship - ones that have an expiration date.

This thesis has shown that women violinists were more numerous and integrated into eighteenth-century European musical culture than is sometimes assumed. A surprising number of violinists from across the continent have surfaced in my research, and I have considered their experiences collectively as women who faced shared problems and solutions. I have also complicated the view that the violin was considered unseemly for women - clearly these violinists and their supporters did not hold this to be true. Indeed, this thesis reveals that there was (and is) a certain amount of disconnection between mainstream written opinion on the matter and actual practice. In the course of analysing Strinasacchi's concerto, I have synthesised different aspects of embodied analysis - namely gender and gesture - and applied these to violin performance. This approach has the potential to be useful in analysis of other violin works, particularly compositions by women violinists, due to the similarities in reception of different women violinists regarding the importance of gesture. My hope is that, far beyond the novelty factor women violinists might bring to eighteenth-century music history, this thesis has shown that these violinists and their achievements hold great potential for further research: they are fascinating in and of themselves, and should no longer be consigned to the wings, but instead be permitted to take centre stage in their own dramas.

${ }^{6}$ Hester Lynch Piozzi, Thraliana: The Diary of Mrs. Hester Lynch Thrale (Later Mrs. Piozzi) 1776-1809, ed. Katharine Canby Balderston (Oxford: Clarendon Press, 1942), 748. Quoted in McVeigh, Concert Life in London, 87; Leppert, Music and Image, 168. 


\section{Bibliography}

Abbate, Carolyn. "Opera; Or, the Envoicing of Women." In Musicology and Difference: Gender and Sexuality in Music Scholarship, edited by Ruth A. Solie, 225-258. Berkeley: University of California Press, 1993.

Allen, Julia. Swimming with Dr Johnson and Mrs Thrale: Sport, Health and Exercise in Eighteenth-Century England. Cambridge: Lutterworth Press, 2012.

André, Naomi. Voicing Gender: Castrati, Travesti, and the Second Woman in Early-Nineteenth-Century Italian Opera. Bloomington, IN: Indiana University Press, 2006.

Arnold, Elsie, and Jane L. Berdes. Maddalena Lombardini Sirmen: Eighteenth-Century Composer, Violinist, and Businesswoman. Lanham, MD: Scarecrow Press, 2002.

Baade, Colleen. "'Hired' Nun Musicians in Early Modern Castile." Chap. 12 In Musical V oices of Early Modern Women: Many-Headed Melodies, edited by Thomasin K. LaMay, 287-310. Aldershot; Burlington: Ashgate, 2005.

—_. "Two Centuries of Nun Musicians in Spain's Imperial City." TRANS: Revista transcultural de música/Transcultural Music Review 15 (2011): 1-22.

Bar-Yoshafat, Yonatan. "Kenner und Liebhaber - Yet Another Look." International Review of the Aesthetics and Sociology of Music 44, no. 1 (2013): 19-47.

Beghin, Tom. "A Composer, His Dedicatee, Her Instrument, and I: Thoughts on Performing Haydn's Keyboard Sonatas." Chap. 14 In The Cambridge Companion to Haydn, edited by Caryl Leslie Clark, 203-225. Cambridge: Cambridge University Press, 2005.

Berdes, Jane L. Women Musicians of Venice: Musical Foundations, 1525-1855. Oxford; New York: Clarendon Press, 1993.

Berdes, Jane L., and Joan Whittemore. A Guide to Ospedali Research. Hillsdale, NY: Pendragon Press, 2012.

Blackman, Cally. "Walking Amazons: The Development of the Riding Habit in England during the Eighteenth Century." Costume Costume 35, no. 1 (2001): 47-58.

Blangini, Mlle. T. Trio à Violon Principal, Second Violon et Basse, composé et dédié à Madame Larcher. Paris: Benoît Pollet, c. 1800.

Breene, Samuel. "Mozart's Violin Sonatas and the Gestures of Embodiment: The Subjectivities of Performance Practice.” Ph.D. diss., Duke University, 2007.

Brosses, Charles de. Selections from the Letters of de Brosses. Translated by Ronald Sutherland Gower. London: K. Paul, Trench, Trübner, \& Co., 1897.

Bullough, Vern L., and Bonnie Bullough. Cross Dressing, Sex, and Gender. Philadelphia: University of Pennsylvania Press, 1993. 
Burney, Charles. The Present State of Music in France and Italy: Or, the Journal of a Tour through Those Countries, Undertaken to Collect Materials for a General History of Music. London: T. Becket and Co, 1771.

Capitani, François de, and Gerhard Aeschbacher. Musik in Bern: Musik, Musiker, Musikerinnen und Publikum in der Stadt Bern vom Mittelalter bis heute. Bern: Historischer Vereins des Kantons Bern, 1993.

Clark, Caryl. "Reading and Listening: Viennese Frauenzimmer Journals and the Sociocultural Context of Mozartean Opera Buffa." The Musical Quarterly 87, no. 1 (2004): 140-175.

Cusick, Suzanne G. Francesca Caccini at the Medici Court: Music and the Circulation of Power. Chicago: University of Chicago Press, 2009.

. "On Musical Performances of Gender and Sex." Chap. 1 In Audible Traces: Gender, Identity, and Music, edited by Elaine Barkin, Lydia Hamessley and Benjamin Boretz, 2548. Zurich; Los Angeles: Carciofoli, 1999.

. "Performing/Composing/Woman: Francesca Caccini meets Judith Butler.” In Musics and Feminisms, edited by Cate Poynton and Sally Macarthur, 79-98. Sydney: Australian Music Centre, 1999.

Day-O’Connell, Sarah. “The Singing Style.” Chap. 8 In The Oxford Handbook of Topic Theory, edited by Danuta Mirka, 238-258. Oxford: Oxford University Press, 2014.

de La Grandville, Frédéric. Dictionnaire biographique des élèves et aspirants du Conservatoire de musique de Paris (1795-1815). L'Institut de recherche sur le patrimonie musical en France, 2014. Accessed 25 October 2015. http:// www.irpmf.cnrs.fr/etudes-et-documents-de-l-irpmfen/corpus/article/le-conservatoire-de-musique-de?lang=fr.

DeNora, Tia. "Embodiment and Opportunity: Bodily Capital, Gender, and Reputation in Beethoven's Vienna." Chap. 9 In The Musician as Entrepreneur, 1700-1914: Managers, Charlatans, and Idealists, edited by William Weber, 185-197. Bloomington, IN: Indiana University Press, 2004.

. "Music into Action: Performing Gender on the Viennese Concert Stage, 1790-1810." Poetics 30, no. 1 (2002): 19-33.

Eisen, Cliff. "The Rise (and Fall) of the Concerto Virtuoso in the Late Eighteenth and Nineteenth Centuries." Chap. 10 In The Cambridge Companion to the Concerto, edited by Simon P. Keefe, 177-191. Cambridge: Cambridge University Press, 2005.

Fallows, David. “Affettuoso.” Grove Music Online, Oxford Music Online, Oxford University Press. Accessed 6 February 2016. http://www.oxfordmusiconline.com/subscriber/article/grove/music/00258.

Feilla, Cecilia. "Regarding Women: The Politics of Beholding in Rousseau's Letter to M. d'Alembert on the Theatre." Women \& Performance: A Journal of Feminist Theory 7, no. 1 (1994): 3-18. 
Fétis, François-Joseph. Nicolo Paganini: With an Analysis of His Compositions and a Sketch of the History of the Violin. London: Schott \& Co., 1860. Reprint, Dover Publications, 2013. Accessed 5 August 2014. http://books.google.co.nz/books?id=cWzCAgAAQBAJ.

Fisher, George, and Judy Lochhead. "Analyzing from the Body.” Theory and Practice 27 (2002): $37-67$.

Geminiani, Francesco. The Art of Playing on the Violin, 1751. Edited by David D. Boyden London; New York: Oxford University Press, 1951.

Gillett, Paula. Musical Women in England, 1870-1914: "Encroacbing on All Man's Privileges". New York: St. Martin's Press, 2000.

Gjerdingen, Robert O. Music in the Galant Style. Oxford; New York: Oxford University Press, 2007.

Glickman, Sylvia. "Introduction." Chap. 1 In From Convent to Concert Hall: A Guide to Women Composers, edited by Sylvia Glickman and Martha Furman Schleifer, 1-11. Westport, CT: Greenwood Press, 2003.

Goehr, Lydia. The Imaginary Museum of Musical Works: An Essay in the Philosophy of Music. Oxford: Clarendon Press, 1992.

Gooley, Dana A. "The Battle against Instrumental Virtuosity in the Early Nineteenth Century." In Franz Liszt and His World, edited by Christopher Howard Gibbs and Dana A. Gooley, 75-111. Princeton: Princeton University Press, 2006.

Gramit, David. Cultivating Music: The Aspirations, Interests, and Limits of German Musical Culture, 1770-1848. Berkeley: University of California Press, 2002.

Granger, Sylvie. "Les musiciennes de 1790: Aperçus sur l'invisibilité." Revue de Musicologie 94, no. 2 (2008): 289-308.

Grave, Floyd. “Freakish Variations on a 'Grand Cadence’ Prototype in Haydn’s String

Quartets." Journal of Musicological Research 28, no. 2-3 (2009/04/30 2009): 119-145.

Green, Lucy. Music, Gender, Education. New York: Cambridge University Press, 1997.

Grevenbroch, Giovanni. Orfane filarmoniche. 1754. In Gli abiti de Veneziani di quasi ogni età con diligenza raccolti, e dipinti nel secolo XVII, vol. 4. Museo Correr, Venice.

H.B. "Berner, Mariane von.” Sophie Drinker Institut. Accessed 13 March 2015. http://www.sophie-drinker-institut.de/cms/index.php/berner-mariane-von. "Blangini, Felicita." Sophie Drinker Institut. Accessed 27 January 2015. http://www.sophie-drinker-institut.de/cms/index.php/blangini-felicita.

Hadlock, Heather. "Sonorous Bodies: Women and the Glass Harmonica." Journal of the American Musicological Society 53, no. 3 (2000): 507-542.

Hatten, Robert S. "The Troping of Topics in Mozart's Instrumental Works." Chap. 19 In The Oxford Handbook of Topic Theory, edited by Danuta Mirka, 514-536. Oxford: Oxford University Press, 2014. 
Hauk. Silhouette of Regina Strinasacchi. 1795. Ink on porcelain. Klassik Stiftung Weimar, Schloss Tiefurt, Weimar.

Head, Matthew. “'Like Beauty Spots on the Face of a Man': Gender in 18th-Century NorthGerman Discourse on Genre." The Journal of Musicology 13, no. 2 (1995): 143-167.

Sovereign Feminine: Music and Gender in Eighteenth-Century Germany. Berkeley: University of California Press, 2013.

Heartz, Daniel. Mozart, Haydn and Early Beethoven, 1781-1802. New York: W.W. Norton, 2009.

Helyard, Erin. "Muzio Clementi, Difficult Music, and Cultural Ideology in Late Eighteenth-

Century England.” Ph.D. diss., Schulich School of Music, McGill University, 2012.

Herold, Anja. "Anna Amalia, Prinzessin von Preußen.” Sophie Drinker Institut. Accessed 27

January 2015. http://www.sophie-drinker-institut.de/cms/index.php/anna-amaliaprinzessin-von-preussen.

—_. "Krähmer, Caroline." Sophie Drinker Institut. Accessed 17 September 2014. http://www.sophie-drinker-institut.de/cmsms/index.php?page=kraehmer-caroline. . "Schleicher, Josepha." Sophie Drinker Institut. Accessed 29 January 2015. http://www.sophie-drinker-institut.de/cms/index.php/schleicher-josepha.

Herold, Anja, and Jannis Wichmann. "Janitsch, Marie.” Sophie Drinker Institut. Accessed 27 January 2015. http://www.sophie-drinker-institut.de/cms/index.php/janitsch-marie. Hoffmann, Freia. “Die Klavierlehrerin: Caroline Krähmer und ein literarisches Stereotyp.” In Musik und Biographie: Festschrift für Rainer Cadenbach, edited by Cordula Heymann-Wentzel and Johannes Laas. 149-161. Würzburg: Königshausen \& Neumann, 2004. Accessed 13 July 2015. http://books.google.co.nz/books?id=DG7t3TgLKyAC.

—. Instrument und Körper: Die musizierende Frau in der bürgerlichen Kultur. Frankfurt a. M.: Insel Verlag, 1991.

“Ladurner, Vorname unbekannt.” Sophie Drinker Institut. Accessed 27 January 2015. http://www.sophie-drinker-institut.de/cms/index.php/ladurner. . "Lebrun, Félicité.” Sophie Drinker Institut. Accessed 9 March 2015. http://www.sophie-drinker-institut.de/cms/index.php/lebrun-felicite. . "Marti-Zbinden, Josepha." Sophie Drinker Institut. Accessed 9 March 2015. http://www.sophie-drinker-institut.de/cms/index.php/marti-zbinden-josepha. - "Schleicher, Cordula." Sophie Drinker Institut. Accessed 29 January 2015. http://www.sophie-drinker-institut.de/cms/index.php/schleicher-cordula. . "Schmeling, Gertrud.” Sophie Drinker Institut. Accessed 16 January 2015. http://www.sophie-drinker-institut.de/cms/index.php/schmeling-gertrud.

Hohl Trillini, Regula. The Gaze of the Listener: English Representations of Domestic Music-Making. Amsterdam; New York: Rodopi, 2008.

Holman, Peter. “Ann Ford Revisited.” Eighteenth-Century Music 1, no. 2 (2004): 157. 
Hunter, Mary. "Topics and Opera Buffa." Chap. 1 In The Oxford Handbook of Topic Theory, edited by Danuta Mirka, 61-89. Oxford: Oxford University Press, 2014.

Iitti, Sanna. The Feminine in German Song. New York: Peter Lang, 2006.

Irigaray, Luce. "Women on the Market." Translated by Catherine Porter. Chap. 8 In This Sex Which Is Not One, 170-191. Ithaca, NY: Cornell University Press, 1985.

Irving, John. “Sonata: 2. Classical.” Grove Music Online, Oxford Music Online, Oxford University Press. Accessed 7 July 2015.

http://www.oxfordmusiconline.com/subscriber/article/grove/music/26191.

Jackson, Barbara Garvey. "Musical Women of the Seventeenth and Eighteenth Centuries."

Chap. 5 In Women and Music: A History, edited by Karin Pendle, 97-173. Bloomington, IN: Indiana University Press, 2001.

James, Kenneth Edward. “Concert Life in Eighteenth-Century Bath.” Ph.D. diss., Royal Holloway, University of London, 1987.

Jarvis, F. Anne M. R. “The Community of German Migrant Musicians in London c1750c1850." Master's thesis, University of Cambridge, 2003. Accessed 6 February 2015. http://www.maydwell.co.uk/german-musicians/dissertation/.

Johnson, James H. Listening in Paris: A Cultural History. Berkeley: University of California Press, 1995.

Kawabata, Maiko. Paganini: The 'Demonic' Virtuoso. Woodbridge, Suffolk; Rochester, NY: The Boydell Press, 2013.

. "Violinists 'Singing': Paganini, Operatic Voices, and Virtuosity." Ad Parnassum: A Journal of Eighteenth- and Nineteenth-Century Instrumental Music 5, no. 9 (2007): 7-39.

—_ "Virtuoso Codes of Violin Performance: Power, Military Heroism, and Gender (17891830)." 19th-Century Music 28, no. 2 (Fall 2004 2004): 89-107.

Kennaway, George. Playing the Cello, 1780-1930. Farnham: Ashgate Publishing Ltd, 2014. Accessed 7 December 2015.

http://VUW.eblib.com/patron/FullRecord.aspx?p=1589636.

Lahee, Henry Charles. Famous Violinists of Today and Yesterday. Boston: L.C. Page and Co., 1899. Accessed 23 October 2014. http://www.gutenberg.org/files/14884/14884-h/14884h.htm\#CHRONOLOGICAL TABLE OF FAMOUS VIOLINISTS.

Lasocki, David. "Quantz and the Passions: Theory and Practice." Early Music 6, no. 4 (1978): 556-567.

Le Guin, Elisabeth. Boccherini's Body: An Essay in Carnal Musicology. Berkeley: University of California Press Berkeley, 2006.

Leppert, Richard D. Music and Image: Domesticity, Ideology, and Socio-Cultural Formation in EighteenthCentury England. Cambridge; New York: Cambridge University Press, 1988. 
- The Sight of Sound: Music, Representation, and the History of the Body. Berkeley: University of California Press, 1993.

Les Tablettes de Polymnie: Journal consacré à tout ce qui interesse l'art musical. Paris, 1810-1811. Reprint, Geneva: Minkoff Reprints, 1971. Accessed 8 August 2015.

http://babel.hathitrust.org/cgi/pt?id=osu.32435056265077; view=1up;seq=254.

Loesser, Arthur. Men, Women, and Pianos: A Social History. New York: Simon and Schuster, 1954.

Lombardini Sirmen, Maddalena Laura. Three Violin Concertos. Edited by Jane L. Berdes Madison: A-R Editions, 1991.

Lowe, Melanie. Pleasure and Meaning in the Classical Symphony. Bloomington: Indiana University Press, 2007.

Marsden, Jean I. Fatal Desire: Women, Sexuality, and the English Stage, 1660-1720. Ithaca, NY: Cornell University Press, 2006.

Mayes, Catherine. "Turkish and Hungarian-Gypsy Styles." In The Oxford Handbook of Topic Theory, edited by Danuta Mirka. Oxford: Oxford University Press, 2014.

McClary, Susan. Feminine Endings: Music, Gender, and Sexuality. London; Minneapolis: University of Minnesota Press, 2002.

McKee, Eric. Decorum of the Minuet, Delirium of the Waltæ: A Study of Dance-Music Relations in 3/4 Time. Bloomington: Indiana University Press, 2012.

McVeigh, Simon. Concert Life in London from Mozart to Haydn. Cambridge; New York: Cambridge University Press, 1993.

- "Concerto of the Individual." Chap. 21 In The Cambridge History of Eighteenth-Century

Music, edited by Simon P. Keefe, 583-612. Cambridge; New York: Cambridge University Press, 2009.

McVeigh, Simon, and Jehoash Hirshberg. The Italian Solo Concerto, 1700-1760: Rhetorical Strategies and Style History. Rochester, NY; Woodbridge, Suffolk, UK: Boydell Press, 2004.

Milligan, Thomas B. The Concerto and London's Musical Culture in the Late Eighteenth Century. Ann Arbor, MI: UMI Research Press, 1983.

Mirka, Danuta. "Introduction." In The Oxford Handbook of Topic Theory, edited by Danuta Mirka, 1-57. Oxford: Oxford University Press, 2014.

Moens-Haenen, Greta. "Vibrato." Grove Music Online, Oxford Music Online, Oxford University Press. Accessed 6 February 2016.

http://www.oxfordmusiconline.com/subscriber/article/grove/music/29287.

Monelle, Raymond. The Musical Topic: Hunt, Military and Pastoral. Bloomington: Indiana University Press, 2006.

Monson, Craig A. Divas in the Convent: Nuns, Music, and Defiance in Seventeenth-Century Italy. Chicago: University of Chicago Press, 2012. 
Montagu, Jeremy, Howard Mayer Brown, Jaap Frank, and Ardal Powell. "Flute." Grove Music Online, Oxford Music Online, Oxford University Press. Accessed 4 February 2016. http://www.oxfordmusiconline.com/subscriber/article/grove/music/40569.

Moon, Anna Maria. In Memoriam: The Rev. W. Leeves, Author of the Air of "Auld Robin Gray". Printed for private circulation, 1887. Accessed 7 September 2014. https://archive.org/stream/inmemoriamrevwle00mooniala\#page/n7/mode/2up. Morrow, Mary Sue. Concert Life in Haydn's Vienna: Aspects of a Developing and Social Institution. Stuyvesant, NY: Pendragon Press, 1989.

. German Music Criticism in the Late Eighteenth Century: Aesthetic Issues in Instrumental Music.

New York; Cambridge, U.K: Cambridge University Press, 1997.

Müller, Ilse, Günther Schweizer, and Peter Werth. Die Familie Remy: Kannenbäcker und

Unternehmer. Eine genealogische Bestandsaufnahme. Tübingen: Legat Verlag GmBh \& Co., 2009. Accessed 12 August 2015.

https://books.google.co.nz/books?id=Y6f3p4Nd f8C\&dq=die + familie + remy + zick + $\underline{1776 \& \text { source }=\text { gbs navlinks s. }}$.

Mulvey, Laura. "Visual Pleasure and Narrative Cinema." Chap. 3 In Visual and Other Pleasures, 14-27. New York: Palgrave Macmillan, 2009.

Okin, Susan Moller. "Rousseau's Natural Woman.” The Journal of Politics 41, no. 2 (1979): 393416.

Page, Janet K. Convent Music and Politics in Eighteenth-Century Vienna. Cambridge: Cambridge University Press, 2014.

Parke, William Thomas. Musical Memoirs: Comprising an Account of the General State of Music in England, from 1784, to the year 1830. London: H. Colburn and R. Bentley, 1830.

Piotrowska, Anna G. Gypsy Music in European Culture: From the Late Eighteenth to the Early Twentieth Centuries. Translated by Guy R. Torr. Boston, New England: Northeastern University Press, 2013.

Piozzi, Hester Lynch. Thraliana: The Diary of Mrs. Hester Lynch Thrale (Later Mrs. Piozzi) 17761809. Edited by Katharine Canby Balderston Oxford: Clarendon Press, 1942.

Pougin, Arthur. Le violon, les violonistes et la musique de violon du XVIe au XVIIIe siècle. Paris: Fischbacher, 1924.

Rapley, Elizabeth. A Social History of the Cloister: Daily Life in the Teaching Monasteries of the Old Regime. Montreal: McGill-Queen's University Press, 2001.

Reich, Nancy B. "Women as Musician: A Question of Class." In Musicology and Difference: Gender and Sexuality in Music Scholarship, edited by Ruth A. Solie, 125-146. Berkeley: University of California Press, 1995. 
Richter, Caroline. "Wilhelmine von Bayreuth.” Sophie Drinker Institut. Accessed 27 January

2015. http://www.sophie-drinker-institut.de/cms/index.php/wilhelmine-von-

bayreuth.

Riley, Matthew. "Civilizing the Savage: Johann Georg Sulzer and the 'Aesthetic Force' of

Music." Journal of the Royal Musical Association 127, no. 1 (2002): 1-22.

-. Musical Listening in the German Enlightenment: Attention, Wonder and Astonishment.

Burlington; Aldershot: Ashgate Pub. Co, 2004.

Ringer, Alexander L. "The 'Chasse' as a Musical Topic of the 18th Century." Journal of the

American Musicological Society 6, no. 2 (1953): 148-159.

Ritchie, Leslie. Women Writing Music in Late Eighteenth-Century England: Social Harmony in Literature and Performance. Burlington; Aldershot: Ashgate, 2008.

Rosa, Mario. “The Nun.” Translated by Lydia G. Cochrane. Chap. 8 In Baroque Personae, edited

by Rosario Villari, 195-238. Chicago: University of Chicago Press, 1995.

Rousseau, Jean-Jacques. The Confessions and Correspondence, Including the Letters to Malesherbes. Edited by Christopher Kelly, Roger D. Masters and Peter G. Stillman London: University Press of New England, 1995.

—. Les confessions de J. J. Rousseau. Paris: Charpentier, 1841.

Letter to D'Alembert and Writings for the Theater. Edited by Allan Bloom, Charles E.

Butterworth and Christopher Kelly London: University Press of New England, 2004.

Sadie, Julie Anne. “Musiciennes of the Ancien Régime.” In Women Making Music: The Western Art

Tradition, 1150-1950, edited by Jane M. Bowers and Judith Tick, 191-223. Urbana:

University of Illinois Press, 1986.

Shifrin, Ken. “The Women's Orchestra of Old Brno.” Early Music America 11, no. 2 (2005): 26$28,46$.

“Signora Luigia Gerbini.” In Zeitung für die elegante Welt, edited by Karl Spazier. 1066. Berlin:

Janke, 29 October 1803. Accessed 1 February 2016. http://www.mdz-nbn-

resolving.de/urn/resolver.pl?urn=urn:nbn:de:bvb:12-bsb10532399-9.

Sisman, Elaine. "Genre, Gesture, and Meaning in Mozart's 'Prague’ Symphony.” In Mozart Studies 2, edited by Cliff Eisen, 27-84. Oxford: Clarendon Press, 1997.

—. "Symphonies and the Public Display of Topics." Chap. 2 In The Oxford Handbook of Topic Theory, edited by Danuta Mirka, 90-117. Oxford: Oxford University Press, 2014.

Smart, Mary Ann. Mimomania: Music and Gesture in Nineteenth-Century Opera. Berkeley: University of California Press, 2004.

Spitzer, John, and Neal Zaslaw. The Birth of the Orchestra: History of an Institution, 1650-1815.

Oxford; New York: Oxford University Press, 2005.

Spohr, Louis. Louis Spobr's Autobiography. London: Longman, Green, Longman, Roberts, \&

Green, 1865. 
“Sprezzatura." Accessed 13 July 2015. http://www.merriamwebster.com/dictionary/sprezzatura.

Stauffer, George B. "Introduction: J.S. Bach, the Breitkopfs, and Eighteenth-Century Music Trade." Bach Perspectives 2 (1996).

Steblin, Rita. "The Gender Stereotyping of Musical Instruments in the Western Tradition." Canadian University Music Review 16, no. 1 (1995): 128-44.

Stevens, Denis. “Musicians in 18th-Century Venice.” Early Music 20, no. 3 (1992): 403-408.

Stowell, Robin. "Performance Practice in the Eighteenth-Century Concerto." Chap. 11 In The Cambridge Companion to the Concerto, edited by Simon P. Keefe, 192-246. Cambridge: Cambridge University Press, 2005.

Strinasacchi, Regina. "Regina Schlick an Luise von Knebel in Jena, Gotha, 5. August 1824." Accessed 13 July 2015.

http://dme.mozarteum.at/DME/briefe/letter.php?mid=73\&cat=4.

Swenson, Rivka. "Optics, Gender, and the Eighteenth-Century Gaze: Looking at Eliza Haywood's Anti-Pamela." Eighteenth Century Eighteenth Century 51, no. 1-2 (2010): 27-43.

Timmermann, Volker. “Bayer, Caroline.” Sophie Drinker Institut. Accessed 10 July 2015. http://www.sophie-drinker-institut.de/cms/index.php/bayer-caroline.

—_. "Crux, Marianne.” Sophie Drinker Institut. Accessed 9 September 2014. http://www.sophie-drinker-institut.de/cmsms/index.php?page=crux-marianne. . "Gautherot, Louise.” Sophie Drinker Institut. Accessed 30 January 2015. http://www.sophie-drinker-institut.de/cms/index.php/gautherot-louise.

—_. "Gerbini, Luigia." Sophie Drinker Institut. Accessed 9 September 2014. http://www.sophie-drinker-institut.de/cmsms/index.php?page=gerbini-luigia. . "Paravicini, Giulia." Sophie Drinker Institut. Accessed 9 September 2014. http://www.sophie-drinker-institut.de/cms/index.php?page=paravicini-giulia. . "Plunket, Elizabeth.” Sophie Drinker Institut. Accessed 13 March 2015. http://www.sophie-drinker-institut.de/cms/index.php/plunket-elizabeth. - "Strinasacchi, Regina." Sophie Drinker Institut. Accessed 8 July 2014. http://www.sophie-drinker-institut.de/cmsms/index.php?page=strinasacchi-regina. Toft, Robert. "Action and Singing in Late 18th- and Early 19th- Century England." Performance Practice Review 9, no. 2 (1996): 146-162.

Tonelli, Vanessa M. "Women and Music in the Venetian Ospedali." Master's thesis, Michigan State University, 2013.

Vial, Stephanie. The Art of Musical Phrasing in the Eighteenth Century: Punctuating the Classical 'Period'. Rochester: University of Rochester Press, 2008.

Wahrman, Dror. The Making of the Modern Self: Identity and Culture in Eighteenth-Century England. New Haven: Yale University Press, 2004. 
Walpole, Horace. “Letter No. 109 to George Montagu, Esq., 17 September 1769.” In Letters of Horace Walpole. London: T. Fisher Unwin, 1890.

Walter-Mazur, Magdalena. "The Musical Practice of the Sandomierz Benedictine Nuns During the Eighteenth Century.” Interdisciplinary Studies in Musicology 11 (2012): 187-198.

Weber, William. “The Contemporaneity of Eighteenth-Century Musical Taste.” The Musical Quarterly 70, no. 2 (1984): 175-194.

_ . "The Muddle of the Middle Classes." 19th-Century Music 3, no. 2 (1979): 175-185.

—. "The Musician as Entrepreneur and Opportunist, 1700-1914." Chap. 1 In The Musician as Entrepreneur, 1700-1914: Managers, Charlatans, and Idealists, edited by William Weber. Bloomington, IN: Indiana University Press, 2004.

White, Chappell. From Vivaldi to Viotti: A History of the Early Classical Violin Concerto. Philadelphia: Gordon and Breach, 1992.

—. "The Violin Concertos of Giornovichi." The Musical Quarterly 58, no. 1 (1972): 24-45.

Wood, Elizabeth. "Sapphonics." Chap. 3 In Queering the Pitch: The New Gay and Lesbian Musicology, edited by Philip Brett, Elizabeth Wood and Gary Thomas, 27-66. New York: Routledge, 2006.

Wood, Gillen D'Arcy. Romanticism and Music Culture in Britain, 1770-1840: Virtue and Virtuosity. Cambridge; New York: Cambridge University Press, 2010.

Woodfield, Ian. Salomon and the Burneys: Private Patronage and a Public Career. Vol. no. 12, Burlington: Ashgate, 2003.

Woodring Goertzen, Valerie. "The Eighteenth Century." Chap. 4 In From Convent to Concert Hall: A Guide to Women Composers, edited by Sylvia Glickman and Martha Furman Schleifer, 91-152. Westport, Conn: Greenwood Press, 2003. 


\section{Appendix A}

\section{List of female violinists active in the eighteenth and early nineteenth centuries, c.1695-1868}

Notes: This list only includes violinists who were born before 1800. It is organised alphabetically by the surname most commonly used for each violinist in written sources. Other surnames (either married or maiden) are included in brackets. Alternative spellings of names are sometimes also included in brackets and are preceded by "or".

Abbreviations used for sources:
A/B - Arnold and Berdes (2002)
MO - Morrow (1989)
B - Berdes (1993)
MV - McVeigh (1993)
G - de La Grandville (2014)
P - Pougin (1924)
H - Hoffmann (1991)
S - Sadie (1986)
MI - Milligan (1983)
SD - Sophie Drinker Institut, Instrumentalistinnen-Lexikon

\begin{tabular}{|l|l|l|}
\hline Name & Dates & Source \\
\hline Abrams, Flora & active in London c.1776-78 & MV \\
\hline Achiapati (Guglielmi), Leila & $\begin{array}{l}1745 \text { Bresica (Lombardy, It.)- } \\
\text { 1795 Venice }\end{array}$ & A/B \\
\hline Allavi, Mlle? & $?$ & MO (p.366) \\
\hline Anna Amalia, Princess of Prussia & 1723 Berlin-1787 Berlin & SD \\
\hline Bayer (or Baier), Caroline* & 1758 Vienna-1803 Vienna & SD \\
\hline von Berner, Mariane & $\begin{array}{l}\text { active in Mitau (now Jelgava, } \\
\text { Latvia) c.1815-20 }\end{array}$ & SD \\
\hline Blanchet, Elisabeth Joséphine & $\begin{array}{l}\text { 1799 Chalonnes (Pays de la } \\
\text { Loire, Fr.)-after 1819? }\end{array}$ & G \\
\hline Blangini (von Klenze), Felicita & 1780 Turin-1844 Munich & SD \\
\hline Bizzenberg (née Huber), Mad. ? & active in Vienna 1790-1808 & SD \\
\hline $\begin{array}{l}\text { Bresson (or Brisson), } \\
\text { Jeanne-Marguerite }\end{array}$ & 1785 Paris-1827 ? & SD \\
\hline Calcagno, Catarina & 1797 Genoa-? & Fétis (1860) \\
\hline $\begin{array}{l}\text { Crux (Hollmann, later Gelbert), } \\
\text { Marianne }\end{array}$ & 1772 Mannheim-after 1807 & SD \\
\hline Cubli, Antonia & c.1726 Venice-? & B, SD \\
\hline
\end{tabular}




\begin{tabular}{|c|c|c|}
\hline Czinka, Panna & $\begin{array}{l}\text { c.1711 Sajógömör ('Gemer' in } \\
\text { German, Slovakia)-1772 }\end{array}$ & $\begin{array}{l}\text { Piotrowska } \\
\text { (2013) }\end{array}$ \\
\hline Fémy, Adèle & before 1800 ?-after 1847 ? & $\mathrm{P}$ \\
\hline $\begin{array}{l}\text { Filipowicz (later Minelli, née Mayer), } \\
\text { Elizabeth }\end{array}$ & $\begin{array}{l}1794 \text { Rastatt (Baden- } \\
\text { Württemberg, Ger.)-1841 } \\
\text { London }\end{array}$ & $\mathrm{SD}$ \\
\hline Gautherot (née Deschamps), Louise & 1763 Paris-1808 London & $\mathrm{SD}$ \\
\hline Gerbini (or Zerbini), Luigia & 1770 Turin-after $1818 ?$ & SD \\
\hline Guilberg (or Gillberg), Mad. ? & active in London in 1795 & MI \\
\hline Hartog, Mad. ? & active in London in c.1792-95 & MV \\
\hline de Hauteterre (Levèsque), Elizabeth & active in Paris c.1737-1768 & SD \\
\hline Herschel, Caroline Lukretia & 1750 Hannover-1848 Hannover & SD \\
\hline Hofdemel (née Porkorný), Magdalena & $\begin{array}{l}1766 \text { Brünn (now Brno, Czech } \\
\text { Republic)-after } 1792 \text { ? }\end{array}$ & SD \\
\hline Janitsch (Schmidt), Marie Susanne & 1762 Bern-after $1805 ?$ & $\mathrm{H}, \mathrm{SD}$ \\
\hline Klinsing, Friederike & c.1800 ?-after $1818 ?$ & $\mathrm{SD}$ \\
\hline $\begin{array}{l}\text { Ladurner (née Magnier), Mad. ? } \\
\text { (also Mussier de Gondreville) }\end{array}$ & $\begin{array}{l}\text { before } 1780 \text { ?-1825 Saint-Denis } \\
\text { (Île-de-France, Fr.) }\end{array}$ & SD \\
\hline Larcher, Clarisse & active in Paris c.1800-1812 & $\mathrm{SD}$ \\
\hline Larrivée (Borghese), Henriette & 1764/65 Paris-1839 Paris & MI, SD \\
\hline Lausch, Klara & active in Vienna 1787 & $\mathrm{MO}$ \\
\hline Lebrun (or Le Brun), Félicité & 1779 ? -possibly before 1838 & G, SD \\
\hline Leeves (née Wathen), Anne & $1754-1826$ & $\begin{array}{l}\text { Moon } \\
(1887)\end{array}$ \\
\hline Lombardini Sirmen, Maddalena & 1745 Venice-1818 Venice & $\mathrm{A} / \mathrm{B}$ \\
\hline Mager, Theresia & $\begin{array}{l}1788 \text { Rastatt (Baden- } \\
\text { Württemberg, Ger.)-after } \\
\text { 1805? }\end{array}$ & SD \\
\hline Mara (née Schmeling), Gertrud & $\begin{array}{l}1749 \text { Kassel (Hesse, Ger.)-1833 } \\
\text { Reval (now Tallinn, Estonia) }\end{array}$ & $\mathrm{SD}$ \\
\hline Marchand, Mlle. ? & $\begin{array}{l}1743 \text { Caën (Lower Normandy, } \\
\text { Fr.)- ? }\end{array}$ & $P(p .279)$ \\
\hline Marie-Adélaïde, Princess of France & $\begin{array}{l}1732 \text { Versailles-1800 Trieste } \\
\text { (Friuli Venezia Giulia, It.) }\end{array}$ & S \\
\hline Marti-Zbinden, Josepha & 1792 Bern-1862? & $\mathrm{SD}$ \\
\hline Meyer, Mad. ? & active c. 1819 & $\mathrm{H}$ \\
\hline Morelli-Fernandez, Maria Maddalena & $\begin{array}{l}\text { c. } 1727 \text { Pistoia (Tuscany, It.)- } \\
1800 \text { Florence }\end{array}$ & $\begin{array}{l}\text { Burney } \\
(1771)\end{array}$ \\
\hline Müller, Elizabeth Catherina & $\begin{array}{l}\text { ? Magdeburg (Saxony-Anhalt, } \\
\text { Ger.)- after } 1828 \text { ? }\end{array}$ & SD \\
\hline dall'Occa, Vittoria & Bologna, active in Italy $1780 \mathrm{~s}$ & Lahee \\
\hline
\end{tabular}




\begin{tabular}{|c|c|c|}
\hline $\begin{array}{l}\text { Paravicini (later Alberganti, née } \\
\text { Gandini), Giulia }\end{array}$ & 1769 Turin-1842? & $\mathrm{SD}$ \\
\hline Paulsen, Charlotte Friederike & 1760 ?- ?, active $1784-1786$ & $\mathrm{SD}$ \\
\hline Payer, Anna* & active 1777 Vienna & $\mathrm{H}, \mathrm{MO}$ \\
\hline della Pièta, Anna Maria & 1695/6 Venice-1782 Venice & $\mathrm{B}$ \\
\hline della Pièta, Chiara & 1718 Venice-1791 Venice & $\mathrm{B}$ \\
\hline Plunkett (Devenish), Elizabeth & 1725 Dublin-1744 London & $\mathrm{SD}$ \\
\hline Quaglia, Mlle. ? & active in $1810 \mathrm{~s}$ & G \\
\hline $\begin{array}{l}\text { Remy, Maria Elisabeth Henriette } \\
\text { Friederike }\end{array}$ & $\begin{array}{l}1761 \text { Bendorf (Rhineland- } \\
\text { Palatinate, Ger.)-1813 Maxsain } \\
\text { (Rhineland-Palatinate, Ger.) }\end{array}$ & $\begin{array}{l}\text { Müller } \\
(2009)\end{array}$ \\
\hline Ringbauer, Josefa (Pepi) & $\begin{array}{l}\text { c.1773, active in Vienna1784- } \\
1803\end{array}$ & $\mathrm{MO}$ \\
\hline Royer, Mlle. ? & $?$ & $\begin{array}{l}\text { Louis de } \\
\text { Carmontelle } \\
\end{array}$ \\
\hline Schleicher (Krähmer), Caroline & $\begin{array}{l}1794 \text { Stockach (Baden- } \\
\text { Württemberg, Ger.)-1868 } \\
\text { Vienna }\end{array}$ & SD \\
\hline $\begin{array}{l}\text { Schleicher (Metzger, later } \\
\text { Ostiggenberg), Cordula }\end{array}$ & $\begin{array}{l}\text { c.1788 Stockach (Baden- } \\
\text { Württemberg Ger.)-1821 } \\
\text { Pforzheim (Baden-Württemberg } \\
\text { Ger.) }\end{array}$ & SD \\
\hline Schleicher (née Straßburger), Josepha & $?$ & $\mathrm{SD}$ \\
\hline Sigl, Clara (Klara) & c.1794 Passau (Bavaria, Ger.)- ? & $\mathrm{MO}, \mathrm{SD}$ \\
\hline Sonneck (or Sonnéque), Adèle, ? & active in Paris $1800-1801$ & G \\
\hline Spohr (née Scheidler), Dorette & $\begin{array}{l}1787 \text { Gotha (Thuringia, Ger.)- } \\
1834 \text { Kassel (Hesse, Ger.) }\end{array}$ & $\mathrm{SD}$ \\
\hline Strinasacchi (Schlick), Regina & $\begin{array}{l}1761 \text { Ostiglia (Lombardy, It.)- } \\
1839 \text { Dresden }\end{array}$ & SD \\
\hline Taylor (Lindley), Hannah & c.1781 Bath-c.1815? & $\begin{array}{l}\text { James } \\
(1987)\end{array}$ \\
\hline Tognini, Rosalie & active 1810 & $\mathrm{SD}$ \\
\hline Tollmann, ? & active 1803-1804 & $\mathrm{H}$ \\
\hline Veimringer, Françoise-Adélaïde & $\begin{array}{l}1769 \text { Le Havre-1810 Le Mans } \\
\text { (Pays de la Loire, Fr.) }\end{array}$ & $\begin{array}{l}\text { Granger } \\
(2008)\end{array}$ \\
\hline Victoire, Princess of France & $\begin{array}{l}1733 \text { Versailles-1799 Trieste } \\
\text { (Friuli Venezia Giulia, It.) }\end{array}$ & S \\
\hline $\begin{array}{l}\text { Wilhelmine, Princess of Prussia and } \\
\text { Magravine of Bayreuth }\end{array}$ & 1709 Berlin-1758 Bayreuth & SD \\
\hline
\end{tabular}

*Hoffmann notes that Caroline Bayer and Anna Payer may have been either the same person or possibly sisters. ${ }^{1}$

${ }^{1}$ Hoffmann, Instrument und Körper, 432 n11. 


\title{
Appendix B
}

\section{Edited Score of Regina Strinasacchi's Violin Concerto in B flat major}

\author{
Notes on the Edition
}

The source of this edition of Strinasacchi's Violin Concerto is a handwritten set of parts made by Wilhelm Griesbach in 1798. These parts make up the seventh piece (though numbered as the sixth) in a bound collection containing eleven instrumental works from the eighteenth through to the mid-nineteenth centuries, with several of the other pieces also in Griesbach's hand. In addition to Strinasacchi, the composers represented include Johann Joachim Quantz (1697-1773) and Ignace Joseph Pleyel (1757-1831), along with later composers such as the Irishman Sir Robert Prescott Stewart (1825-1894). The manuscript is currently held by the British Library - with whose kind permission the concerto is reproduced here - and is part of the Royal Music Library Manuscripts Collection, Instrumental Music (First Series) Vol. IV, shelfmark GB-Lbl R.M.21.d.7, ff. 105-130.

The manuscript of Strinasacchi's concerto appears to be in Griesbach's hand throughout. The music is preceded by several pages with various non-musical inscriptions. The first is a title page with the inscription 'Concerto by Mad. ${ }^{\mathrm{m}}$ Schlick,' above which the words 'Three Quartettos by G. [illegible]' have been crossed out. The inscription 'W. Gr: 1798' also appears in the bottom right hand corner. This is followed by the first page from a printed copy of a Quantz triosonata (which continues after the final page of Strinasacchi's concerto), while the third page has 'Mad. ${ }^{\mathrm{m}}$ Schlick' written in the top right hand corner and 'Concerto Bb' written below in pencil in another hand (that is, not Griesbach's). The forth page is blank while the fifth is full of empty staves with 'Violino Principale' written in the middle of the page. The solo violin (violino principale) part begins on the sixth page (numbered p. 107). This is followed by the first violin (violino primo) part on p. 112, second violin (violino secondo) on p. 116, viola on p. 120, basso (i.e. cellos and double basses) on p. 122, first oboe (oboe primo) on p. 126, second oboe (oboe secondo) on p. 127, first horn (corno primo) on p. 128, and second horn (corno secondo) on p. 129, after which the next page of the Quantz triosonata appears. The violin and violas parts are, like the solo violin part, preceded by a page of empty staves 
with the instrument name written in the middle. There are no individual parts for flutes, but the first and second oboe parts for the Adagio have the inscription 'con Flauti' written below the movement title. In the score presented here, the 'con Flauti' marking has been included at the beginning of each line of the oboe part. It should also be noted that, given that this is a late eighteenth-century concerto, transverse flutes were probably intended. ${ }^{2}$

In addition the page numbers listed above (found in the top right hand corner of each right hand page) there are a number of pencil markings on the manuscript that may have been made after 1798. Some of these appear to be unrelated to performance, including a cross in the left hand margin of system four of p. 118 in the second violin Adagio part (there is also a letter - possibly an 'l' - written above the dotted crotchet ab in b. 19) and a cross in the right hand margin after the final bar of the first horn Allegro part. Performance markings in the orchestral parts include a sharp placed before the $f$ ' in b. 96 of the first violin Allegro part, and an a marked above the $\mathrm{f}$ in b. 110 of the basso Rondo part. There are no pencil markings visible in the viola, first and second oboe, and second horn parts.

The solo violin part has further pencil markings. In the Allegro bb. 59, 60, and 83 have slurs marked, while bb. 63 and 70 have what may either be the numeral one written above the stave (making these fingering suggestions) or a wedge articulation marking. There is also a cross above the penultimate semiquaver in b. 70 . The Adagio contains the most substantial markings, specifically the beginning of a cadenza written in small notes following the final bar of the movement. This cadenza consists of twelve notes forming a descending arpeggio $G$ major embellished with lower neighbour notes followed by a short chromatic scale. No pencil markings appear in the Rondo.

The version of the score present here contains a number of editorial markings and alterations. Notation of rests and dynamic markings have been standardised where what is presented in the source differs from modern practice (i.e. ffmo has been changed to ff; po or pia to p). Editorial additions for dynamics and solo/tutti markings appear in square brackets and slurs are dashed. Where two or more parts contain contradictory slurring this idiosyncrasy has been retained. Editorial accidentals are included in small type in

\footnotetext{
2 Jeremy Montagu et al., "Flute," Grove Music Online, Oxford Music Online, Oxford University Press, accessed 4 February 2016, http://www.oxfordmusiconline.com/subscriber/article/grove/music/40569.
} 
three places: in b. 96 of the first violin part of the Allegro, in b. 146 of the solo violin part of the Rondo, and in b. 188 of the basso part of the Rondo.

In two instances in the Allegro note values in otherwise rhythmically unison sections do not match. This discrepancy has been retained and can be seen in the oboe parts in b. 42 (where there is a minim as opposed to a dotted minim, as in the other parts), and in the horn parts in b. 212 (where the horns have a dotted minim while all other parts have a minim). One pitch in the first violin part of the Allegro has been corrected, where the last note of b. 81 has been changed from b b' (clearly a mistake) to $\mathrm{c}^{\prime}$. In the source version of the Rondo, the refrain repeats for the viola, oboes, and horns are indicated by dal segno or da capo markings. This is also the case for the first refrain repeat in the solo violin part (after b. 65). For the sake of clarity the refrain has been written out in full every time it appears in this score. 


\section{Concerto in B flat major}
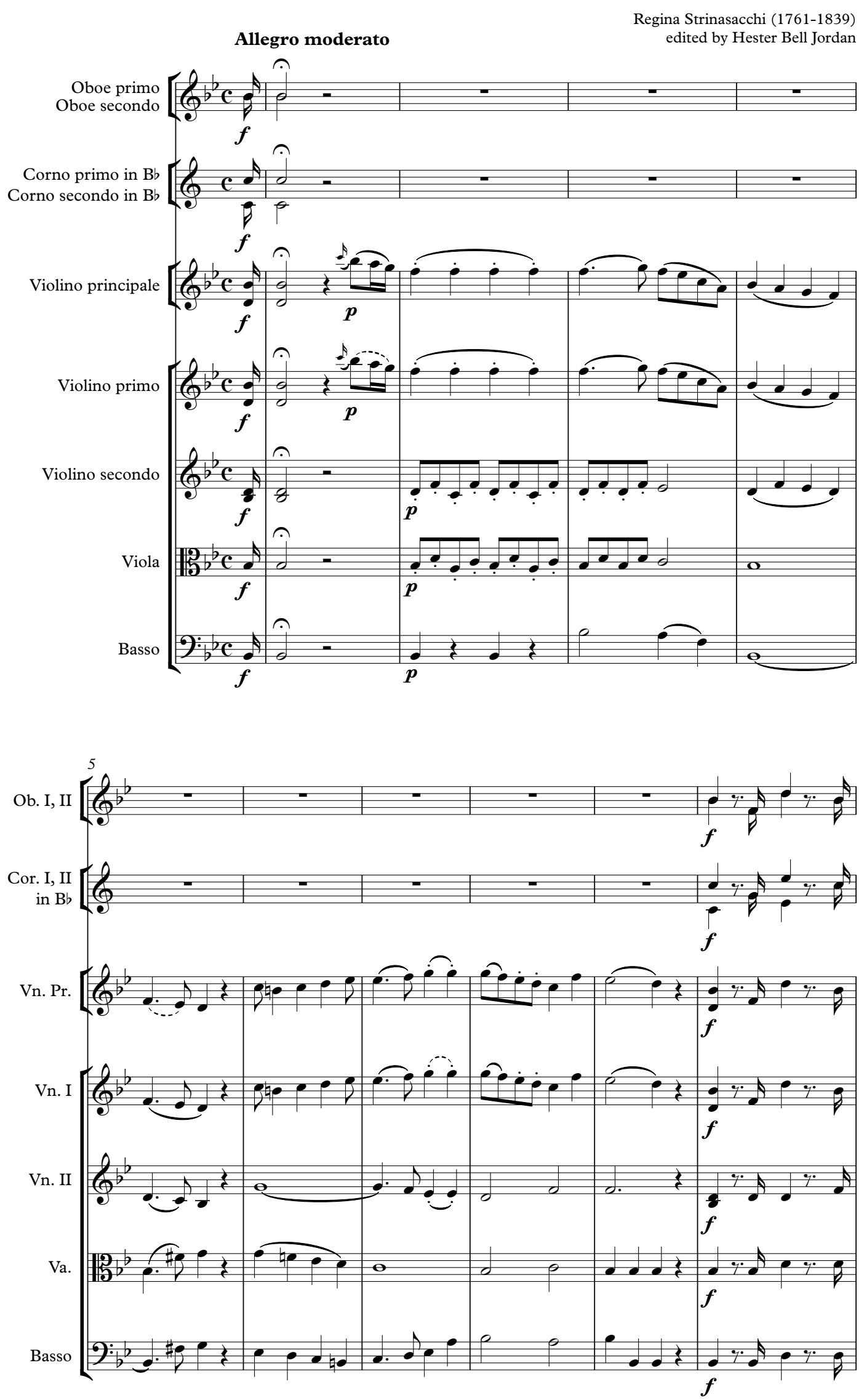

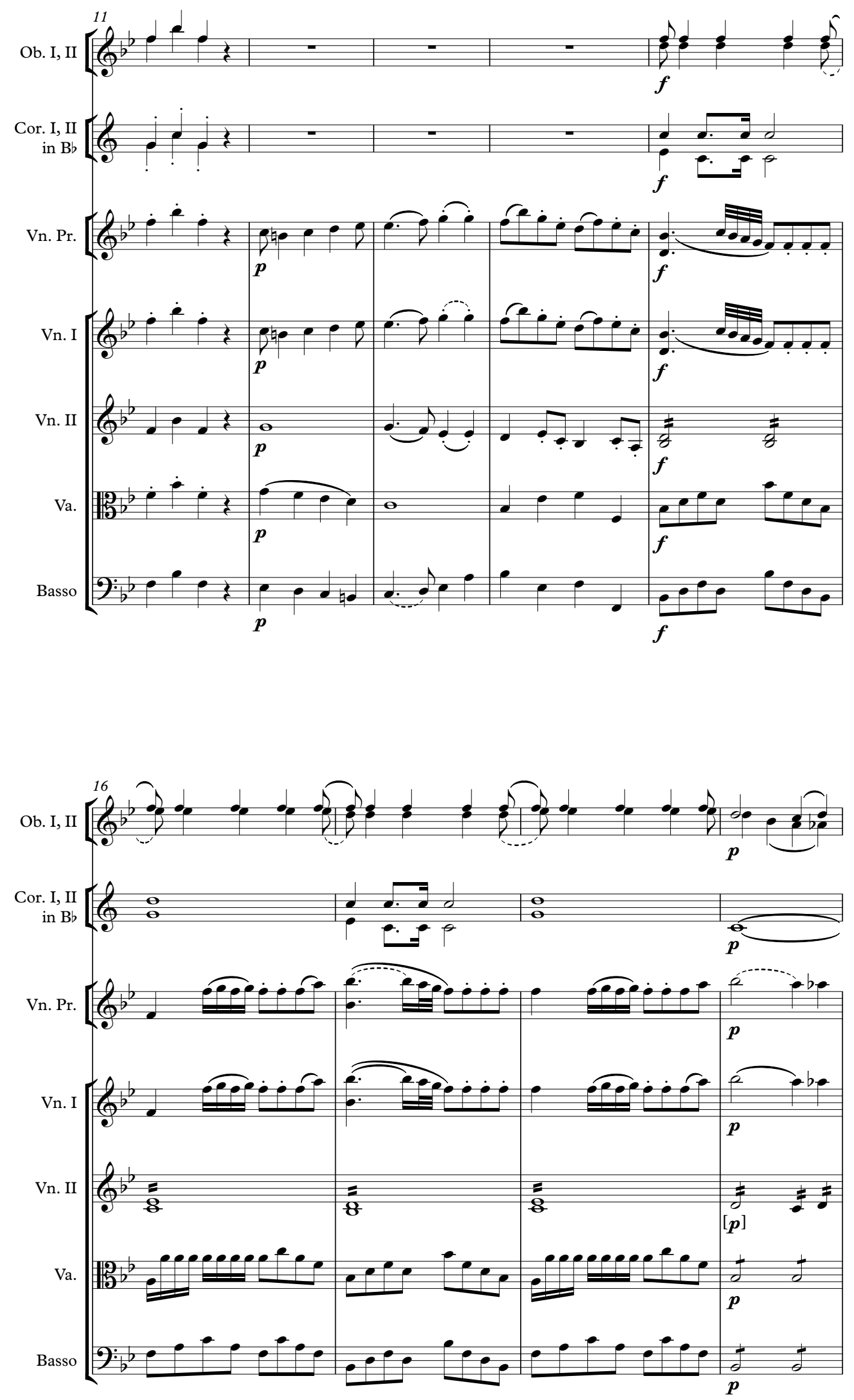

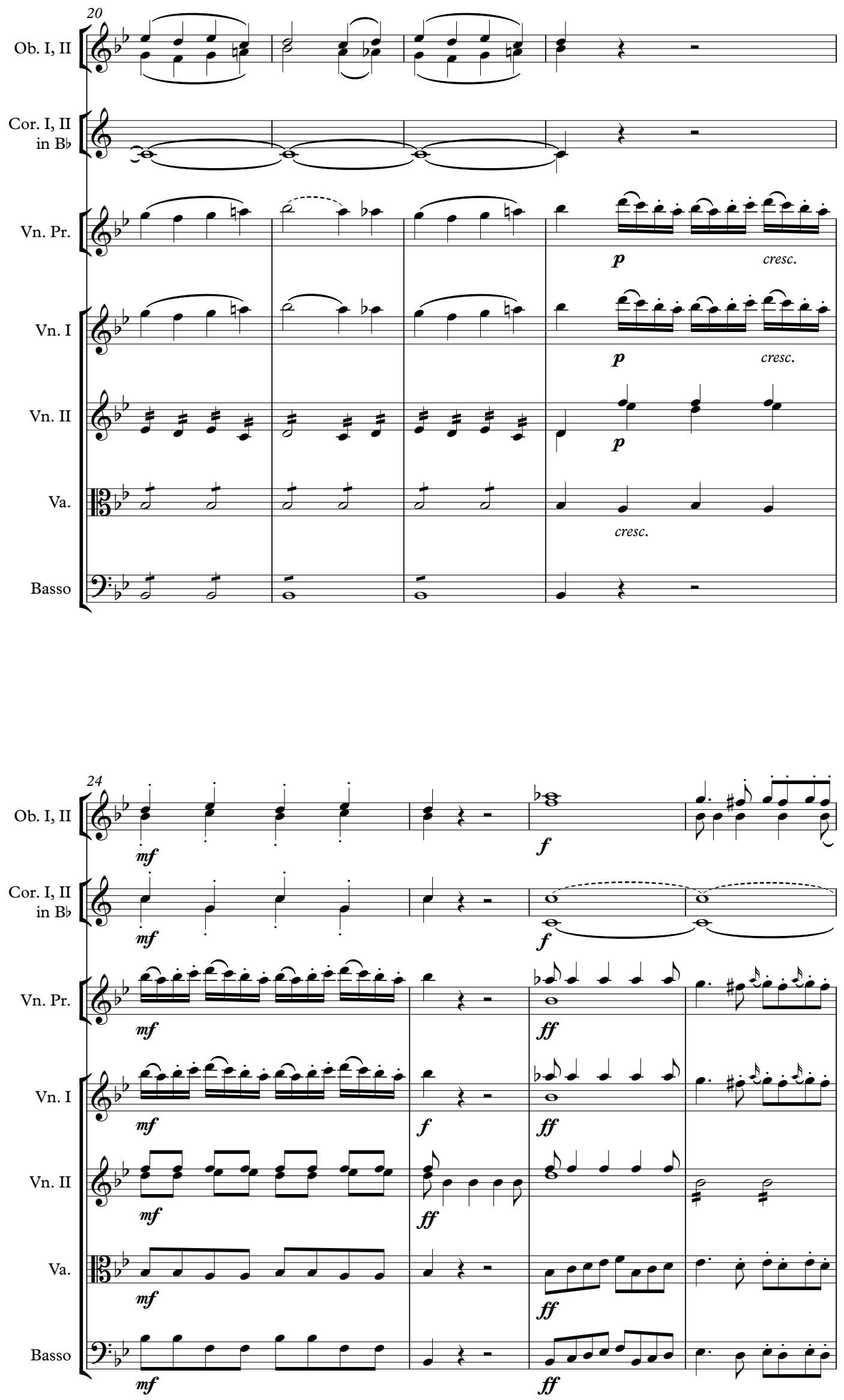

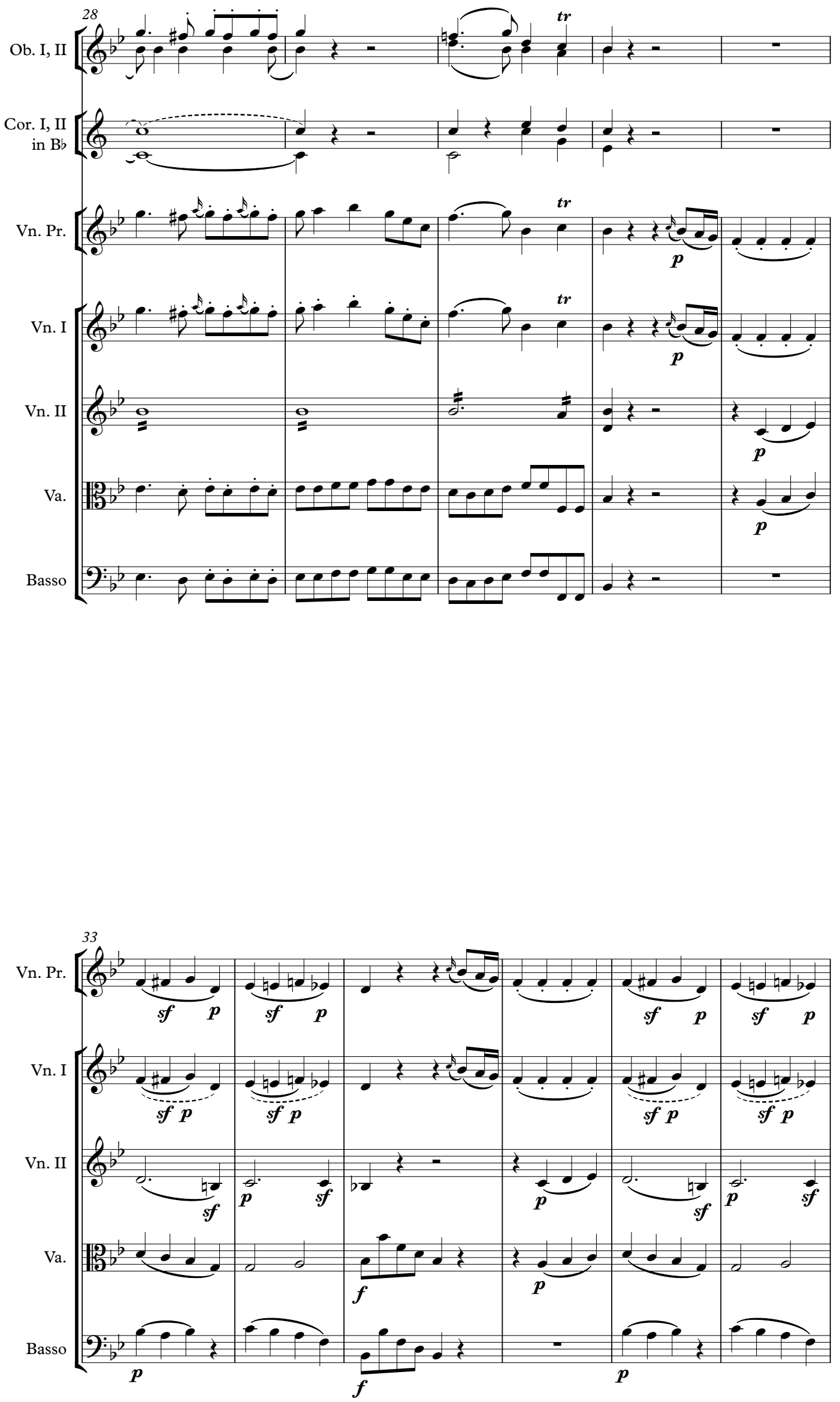
5
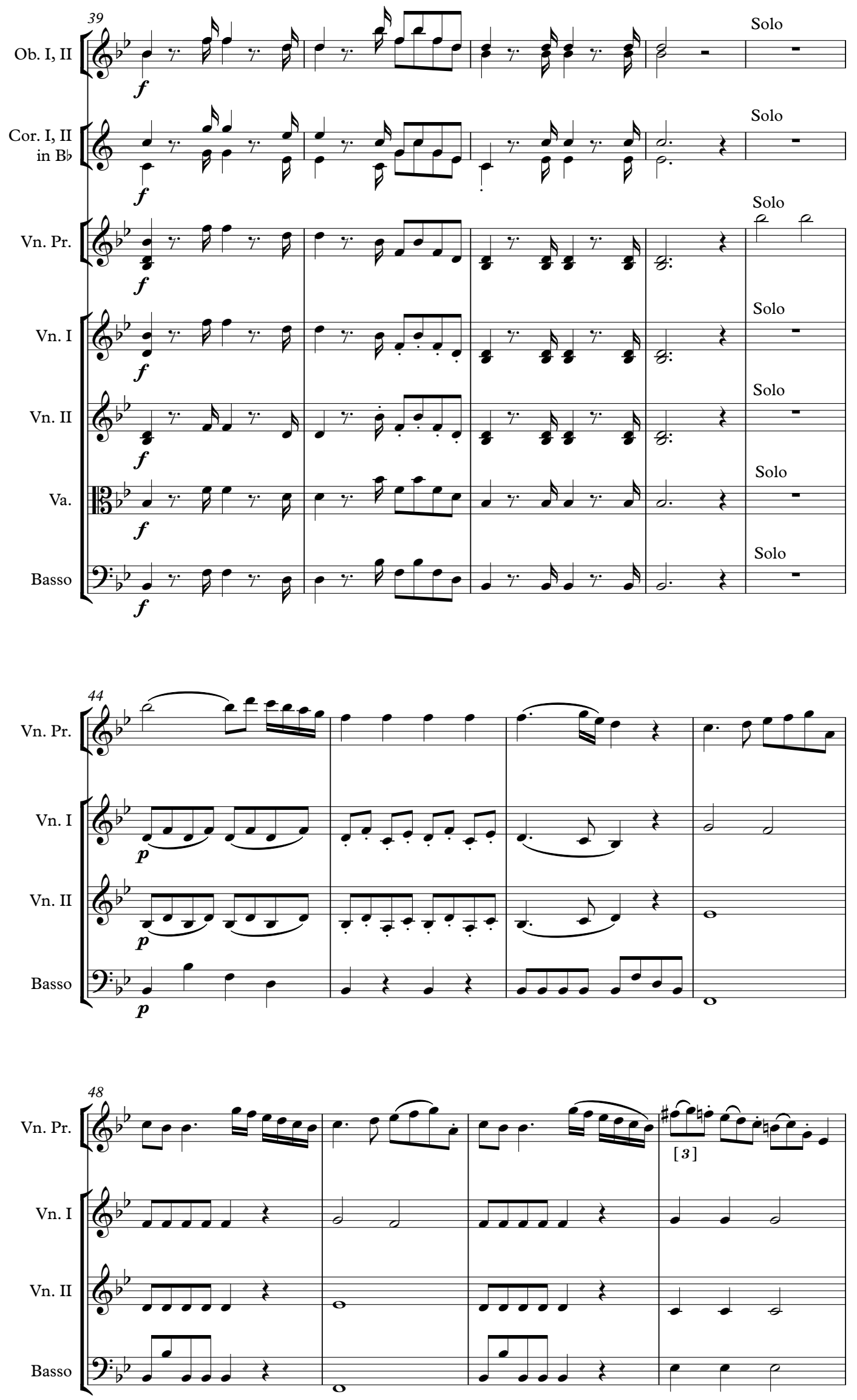

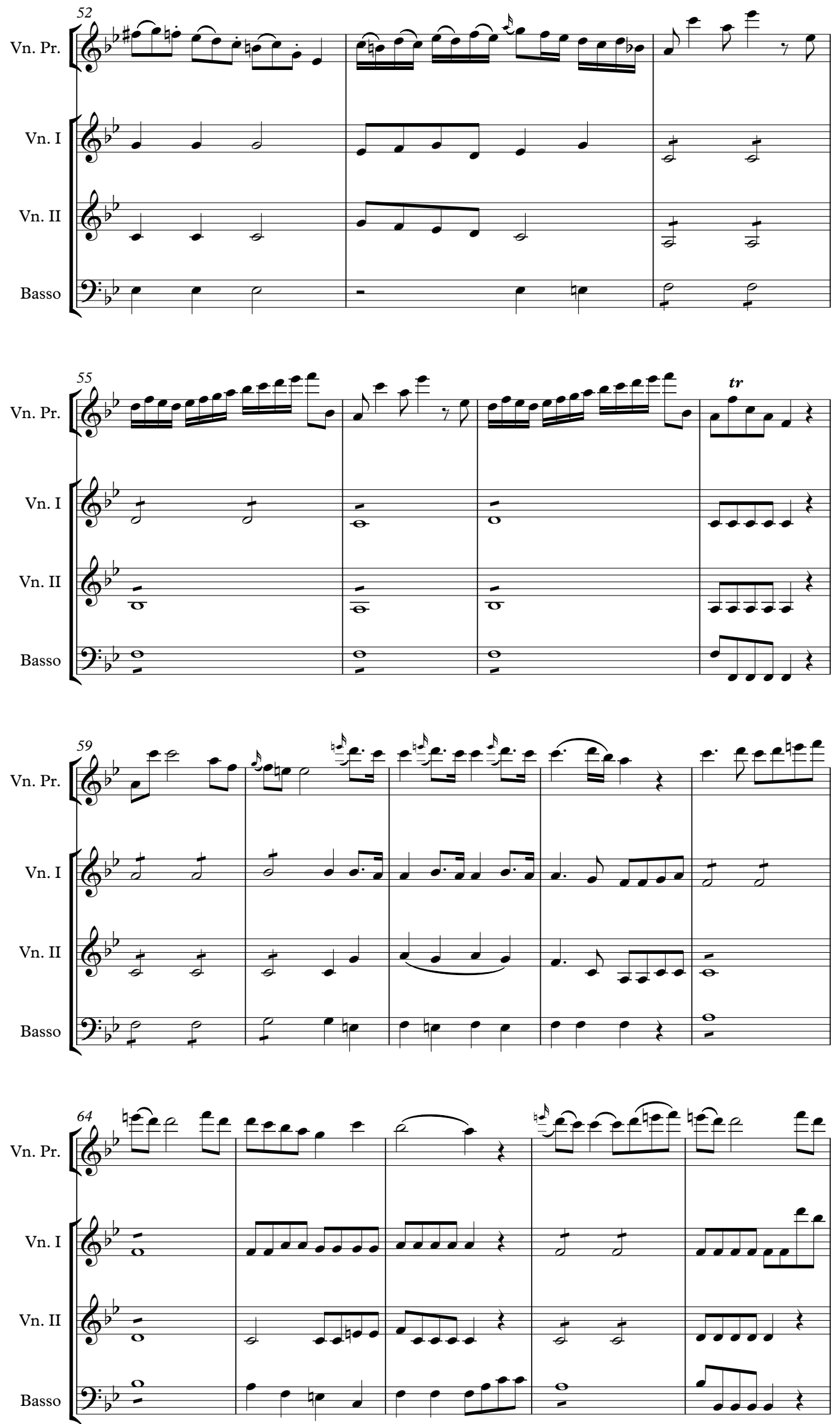

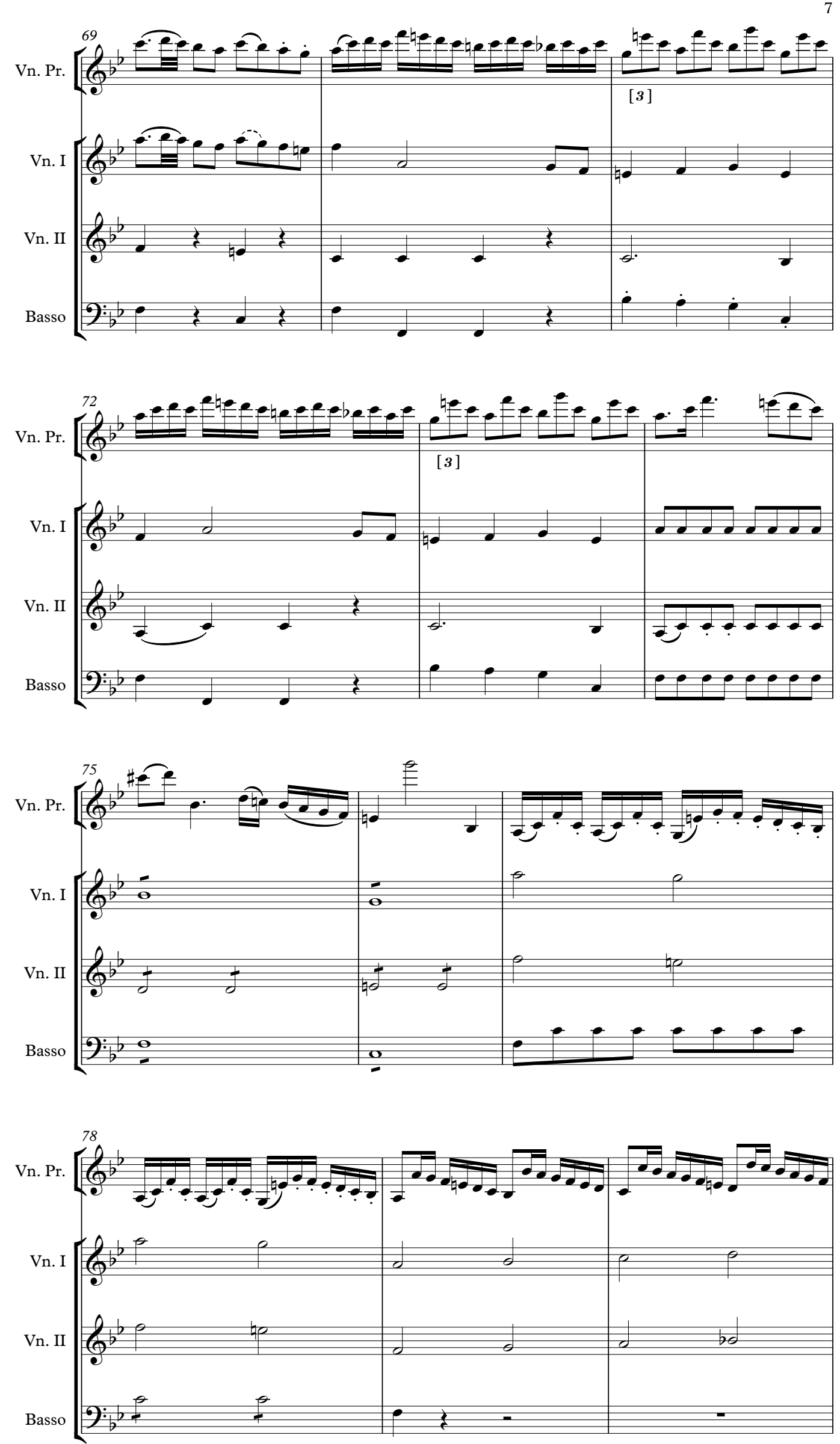

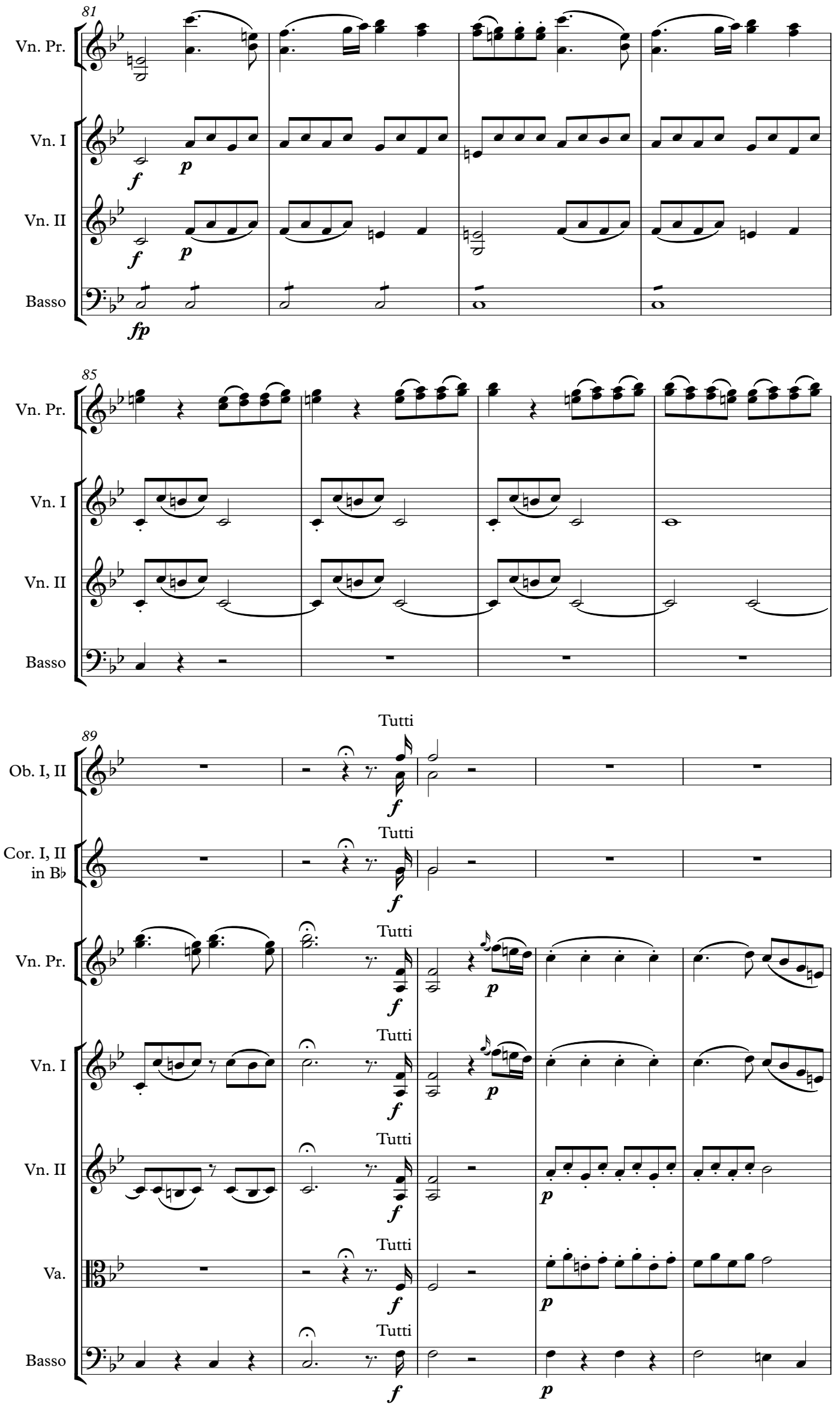
9
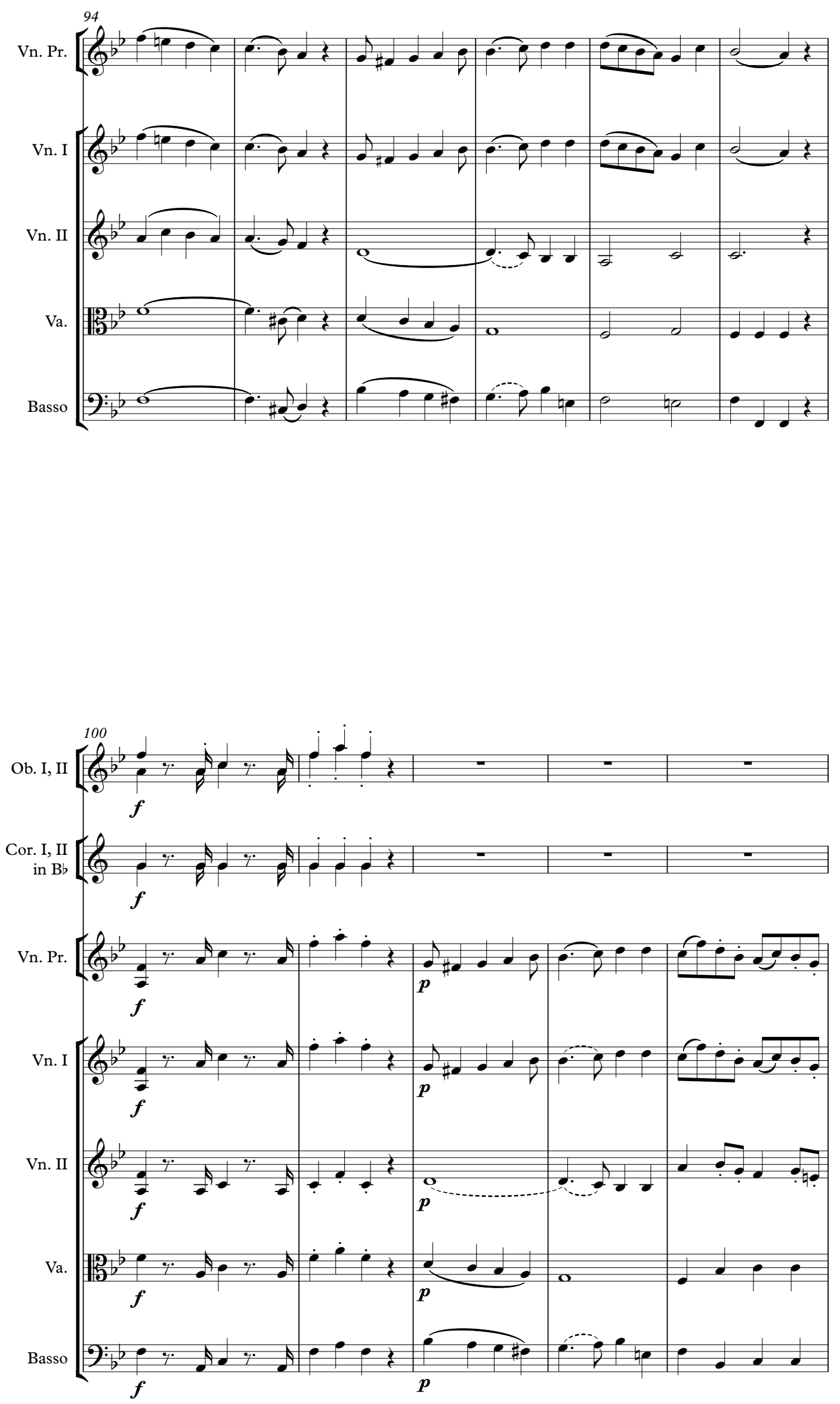

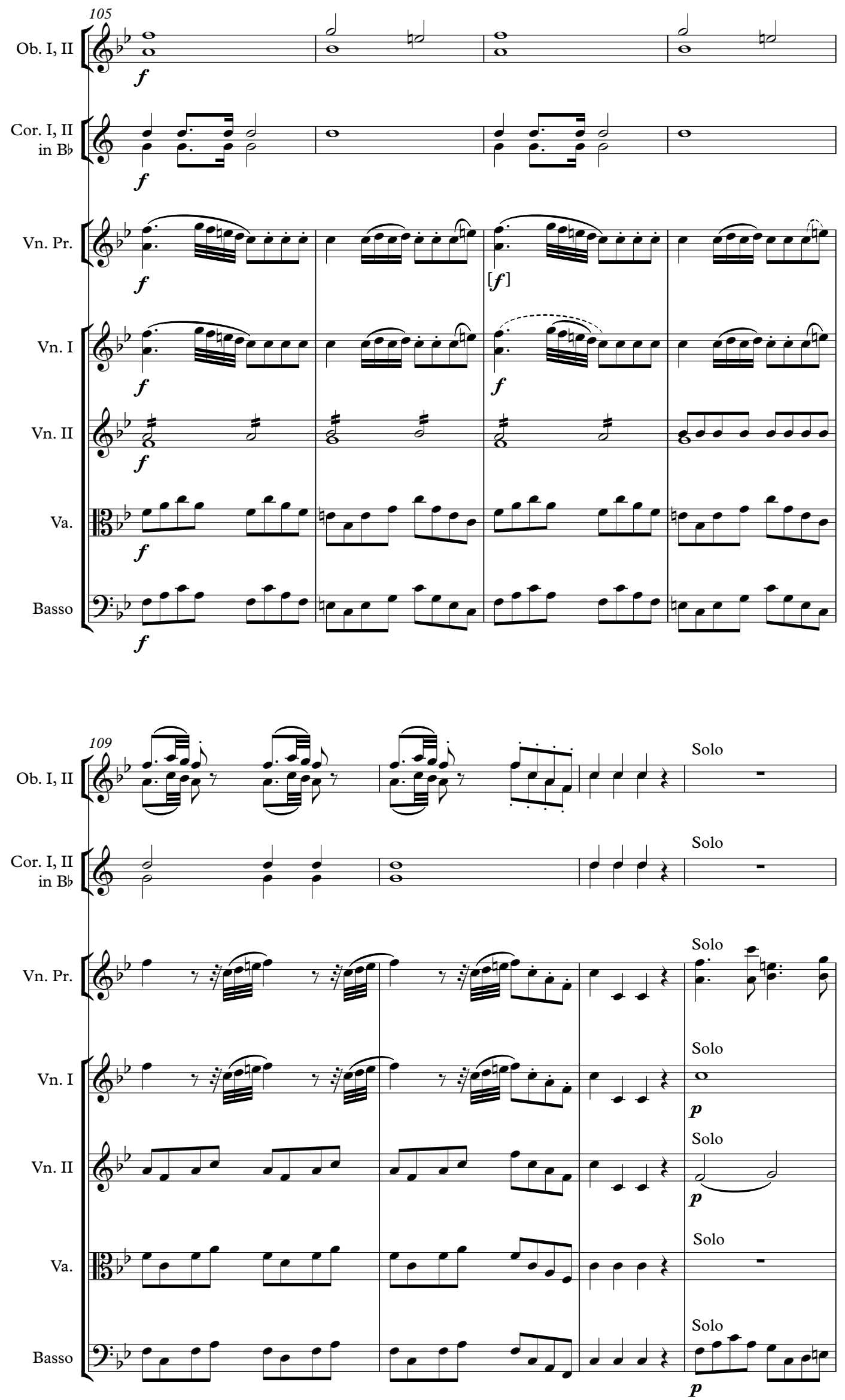

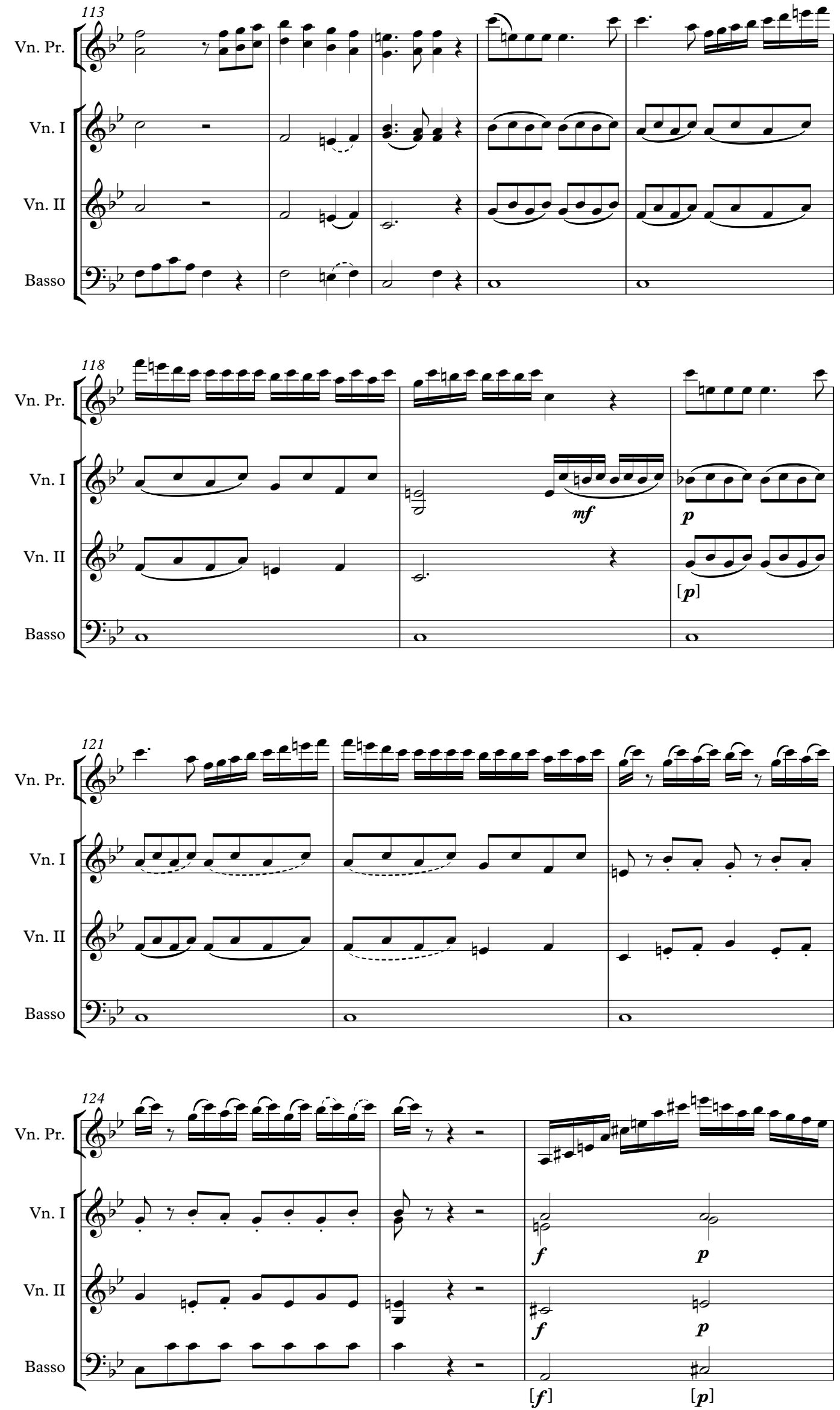
12
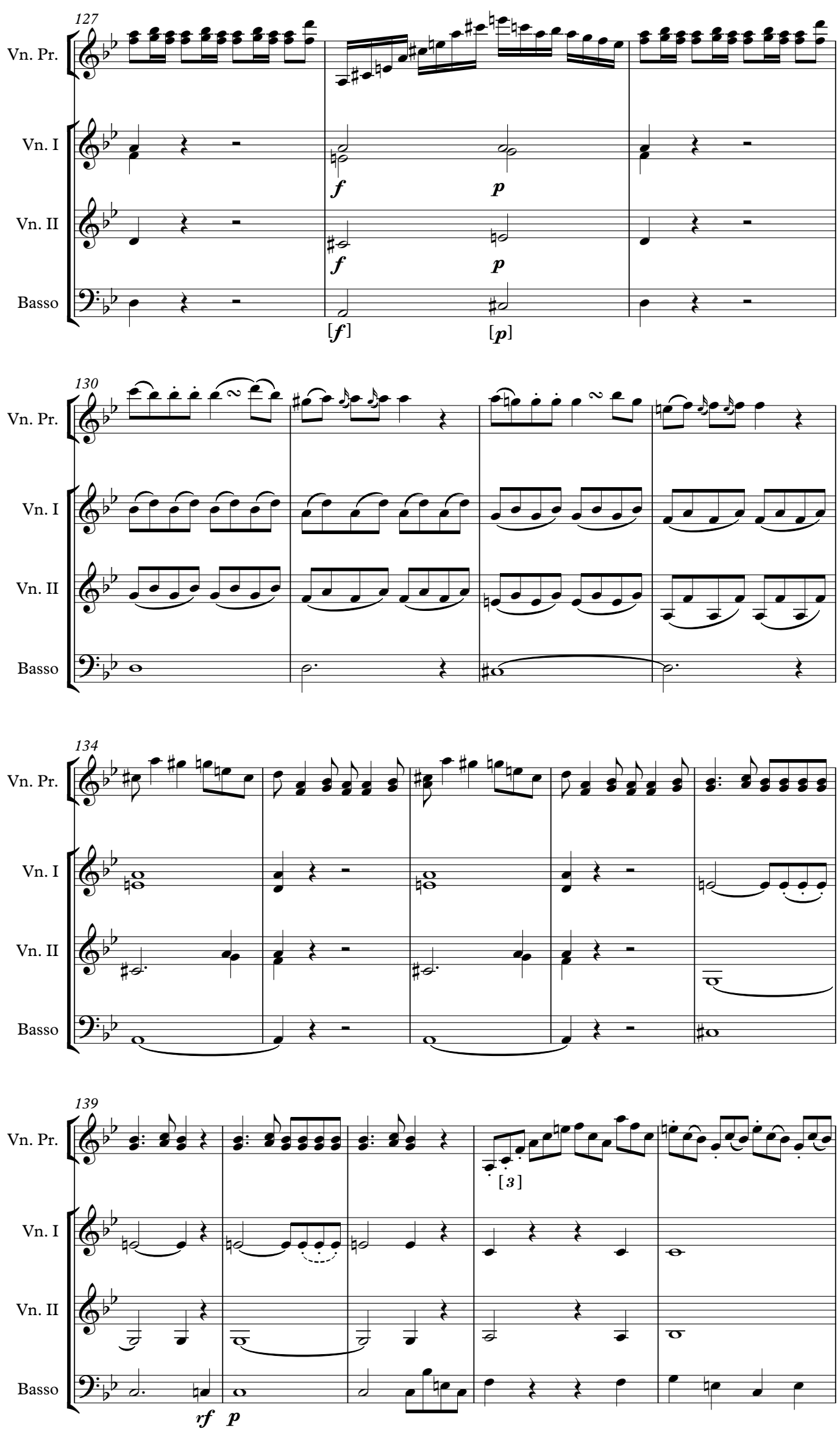

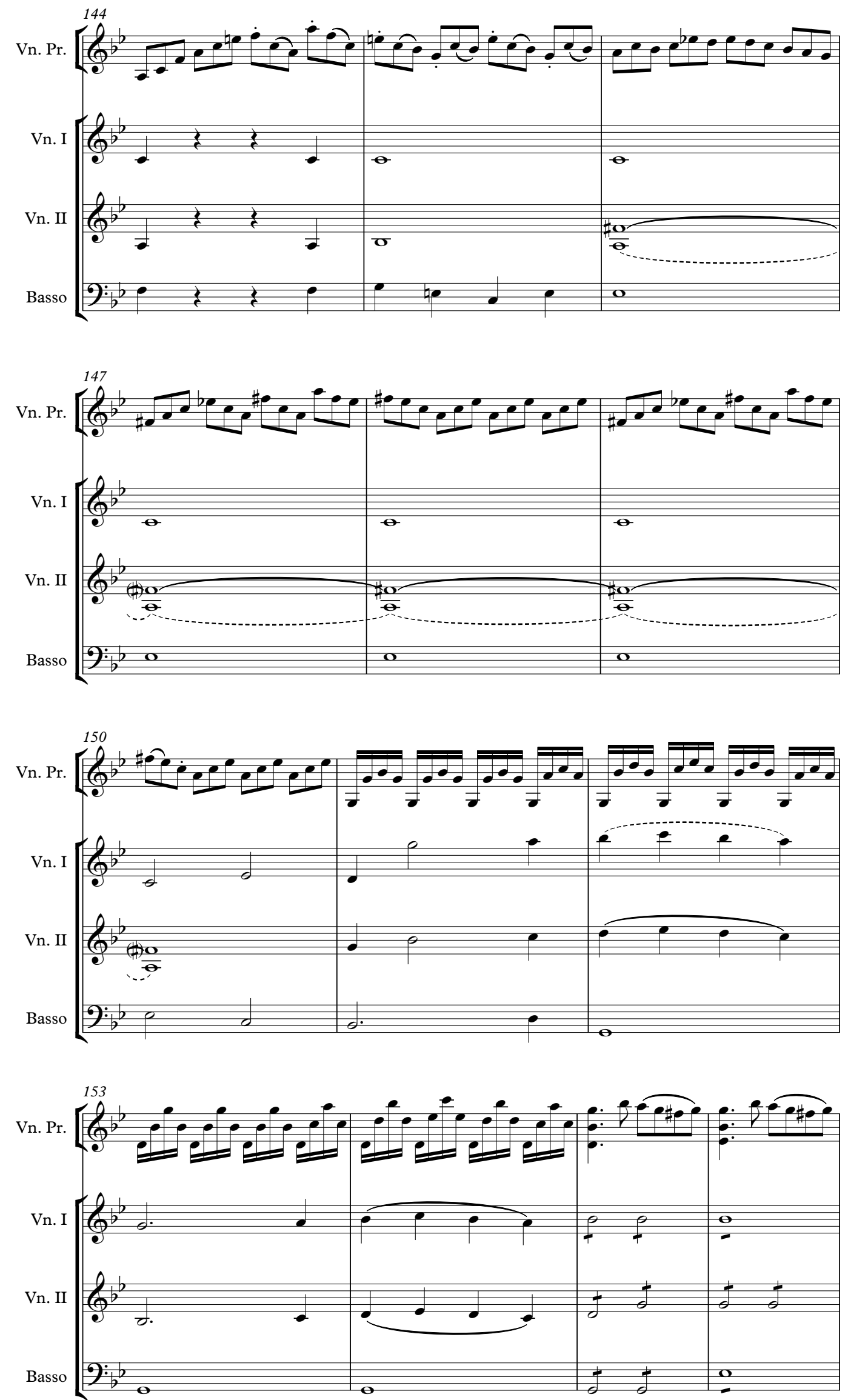
14
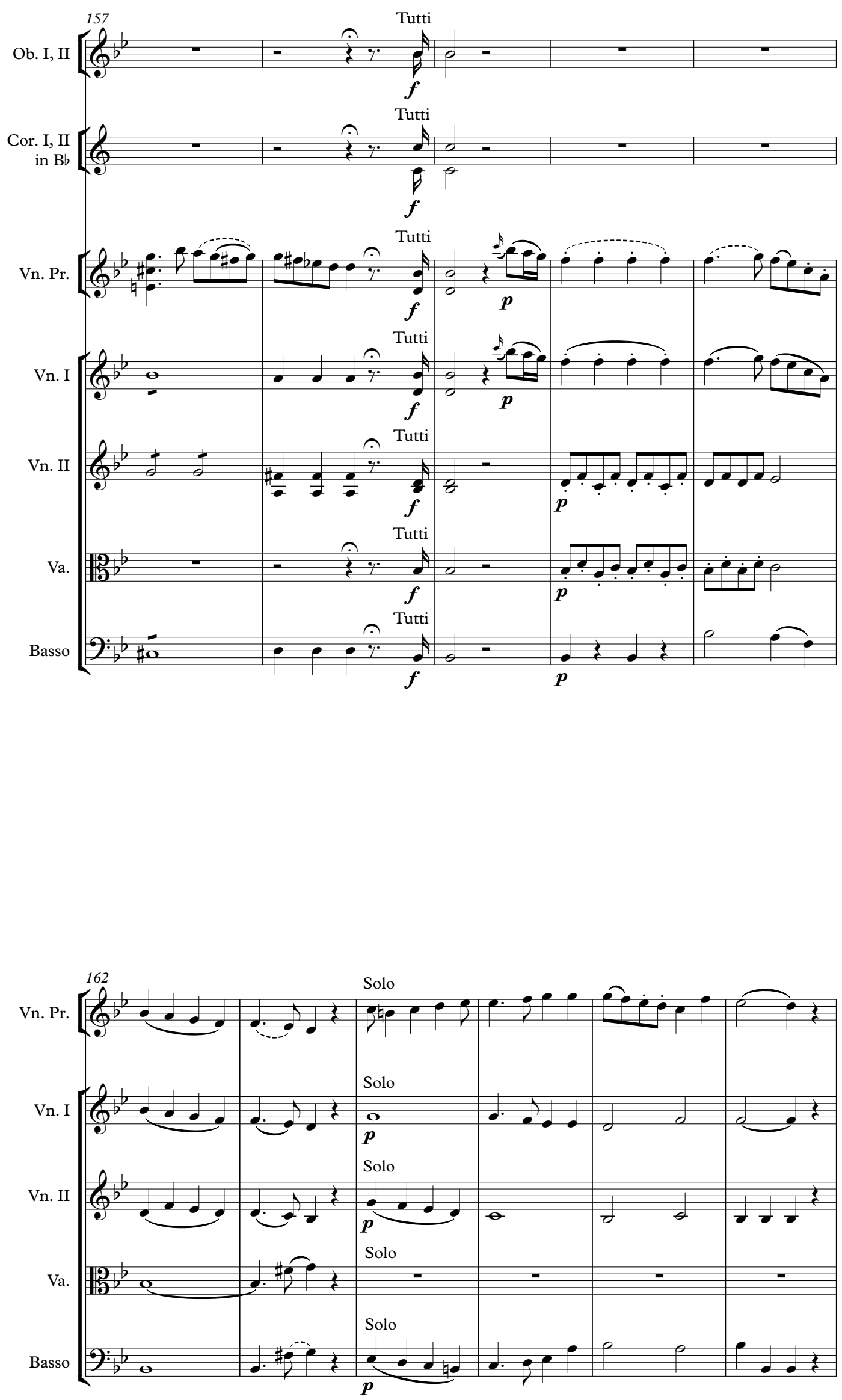
15
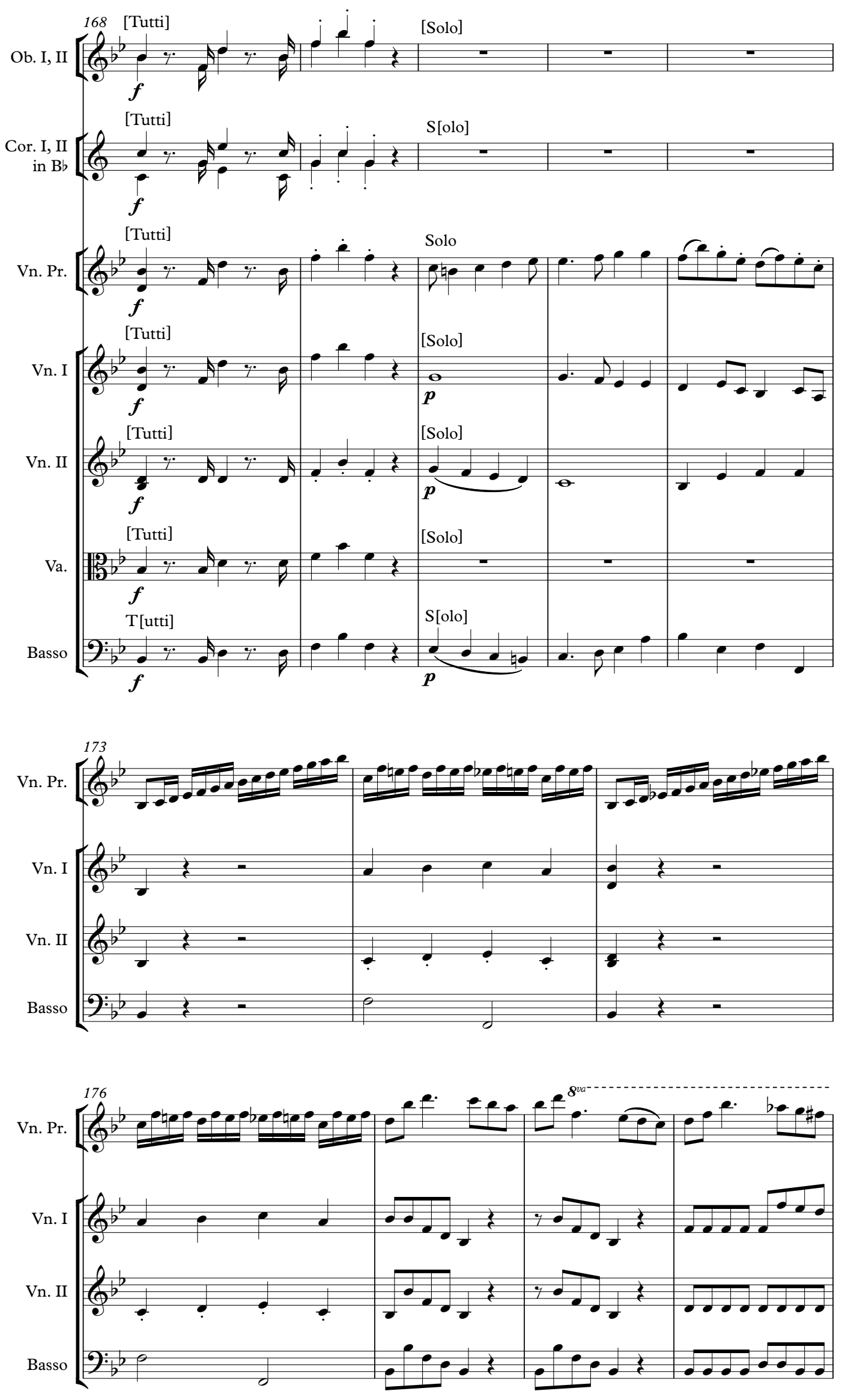
16
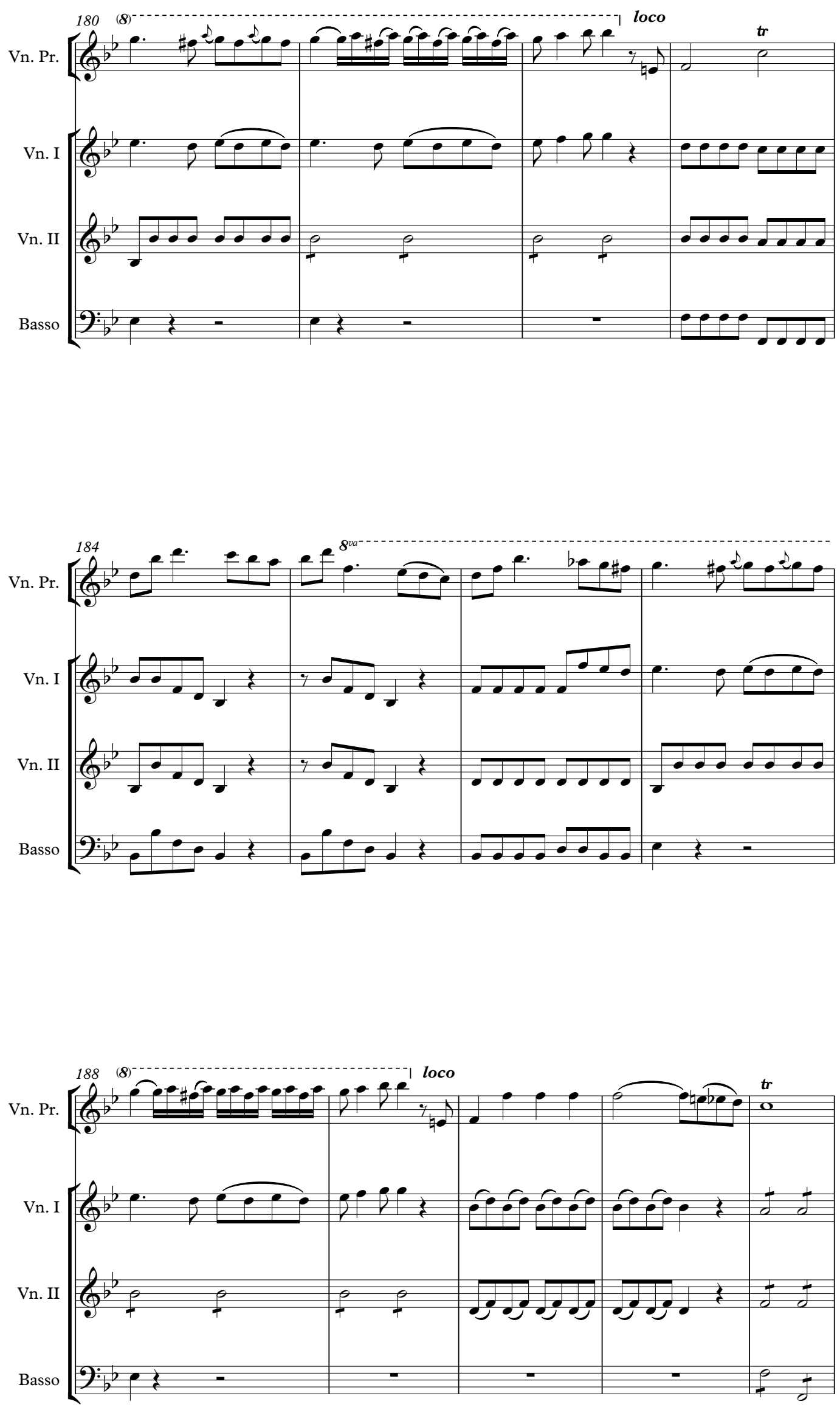


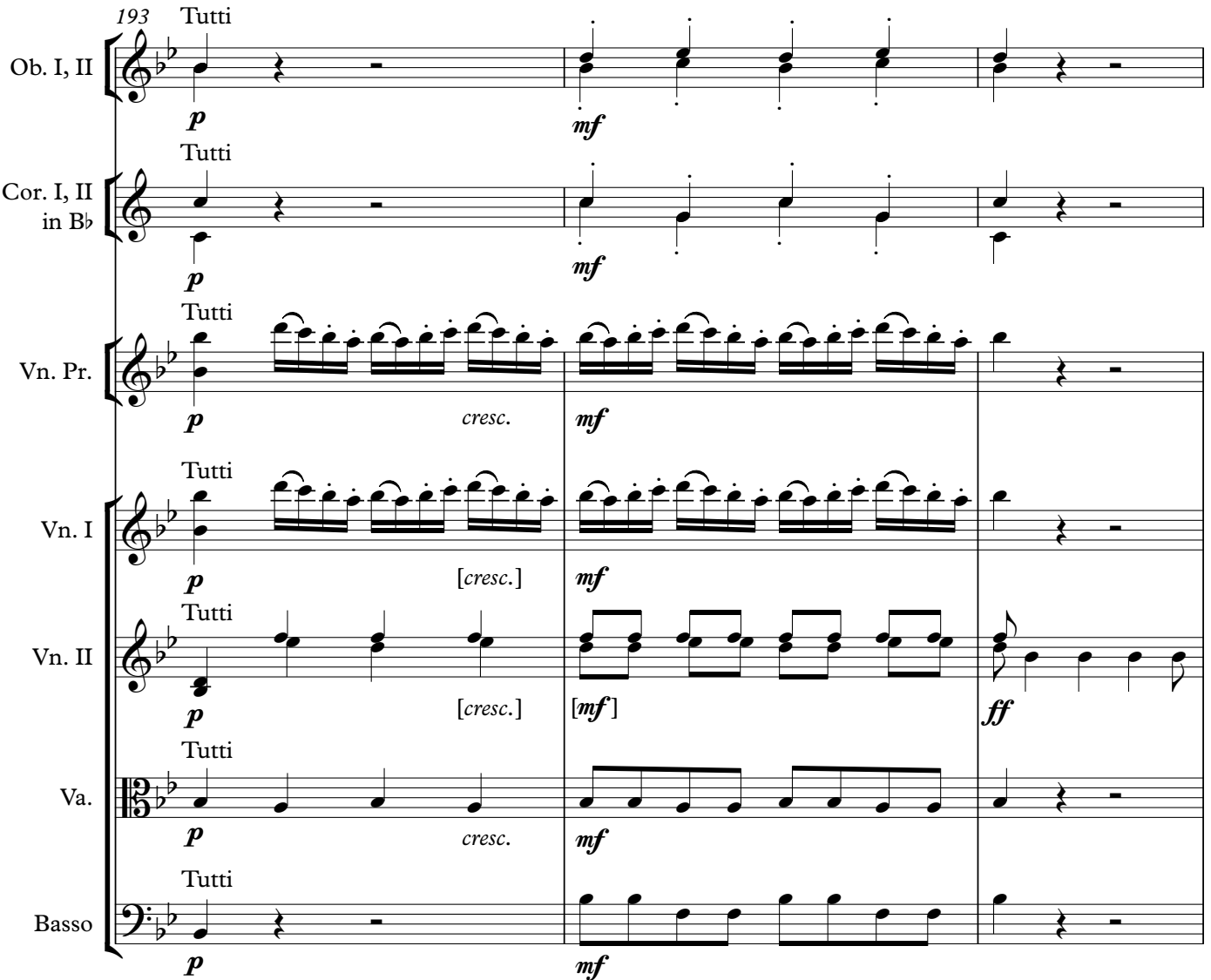

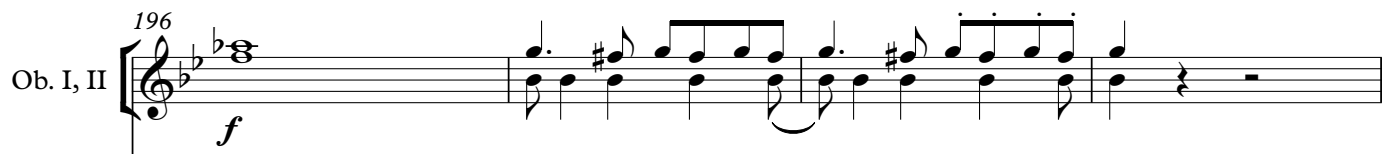
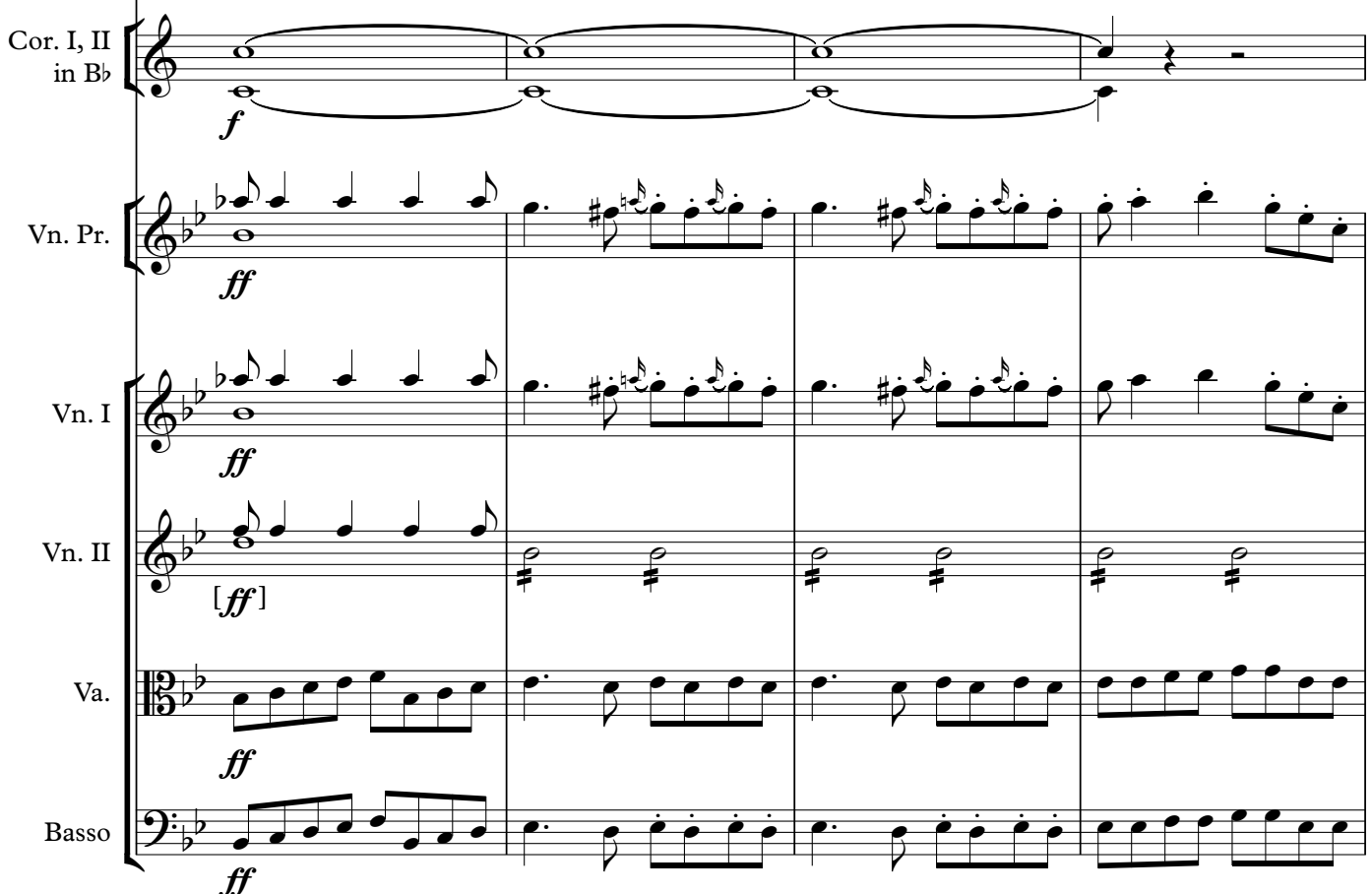

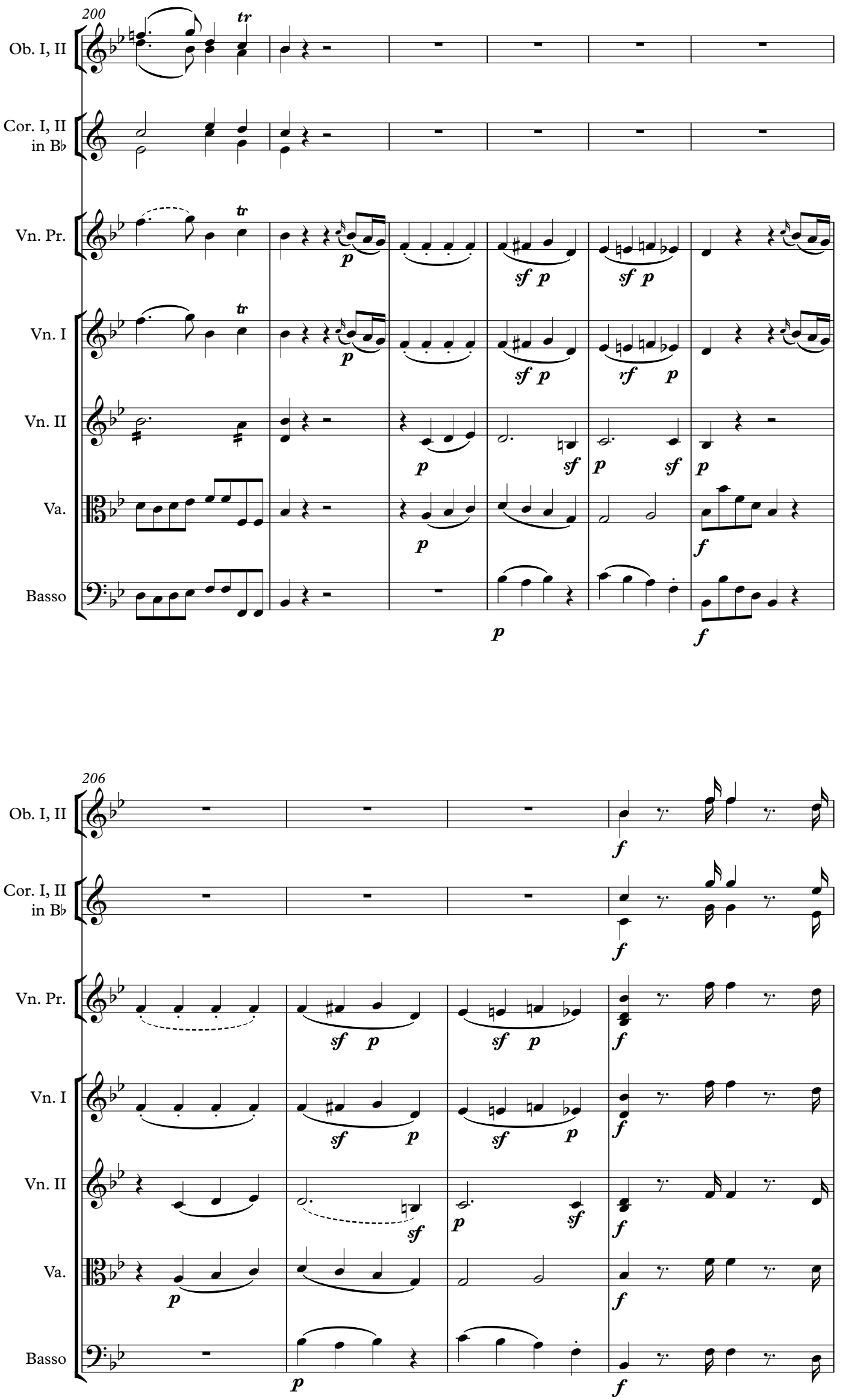
19
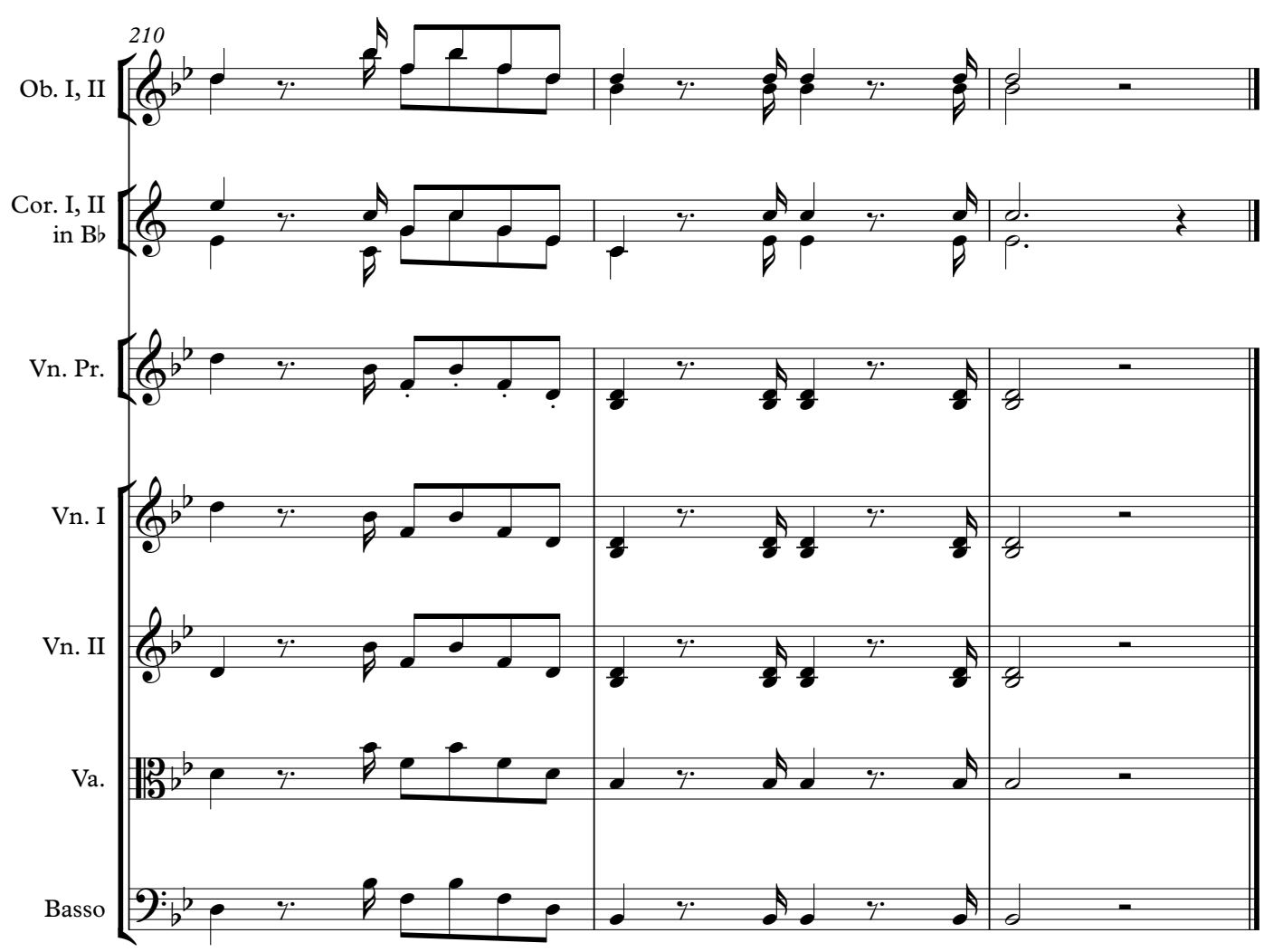

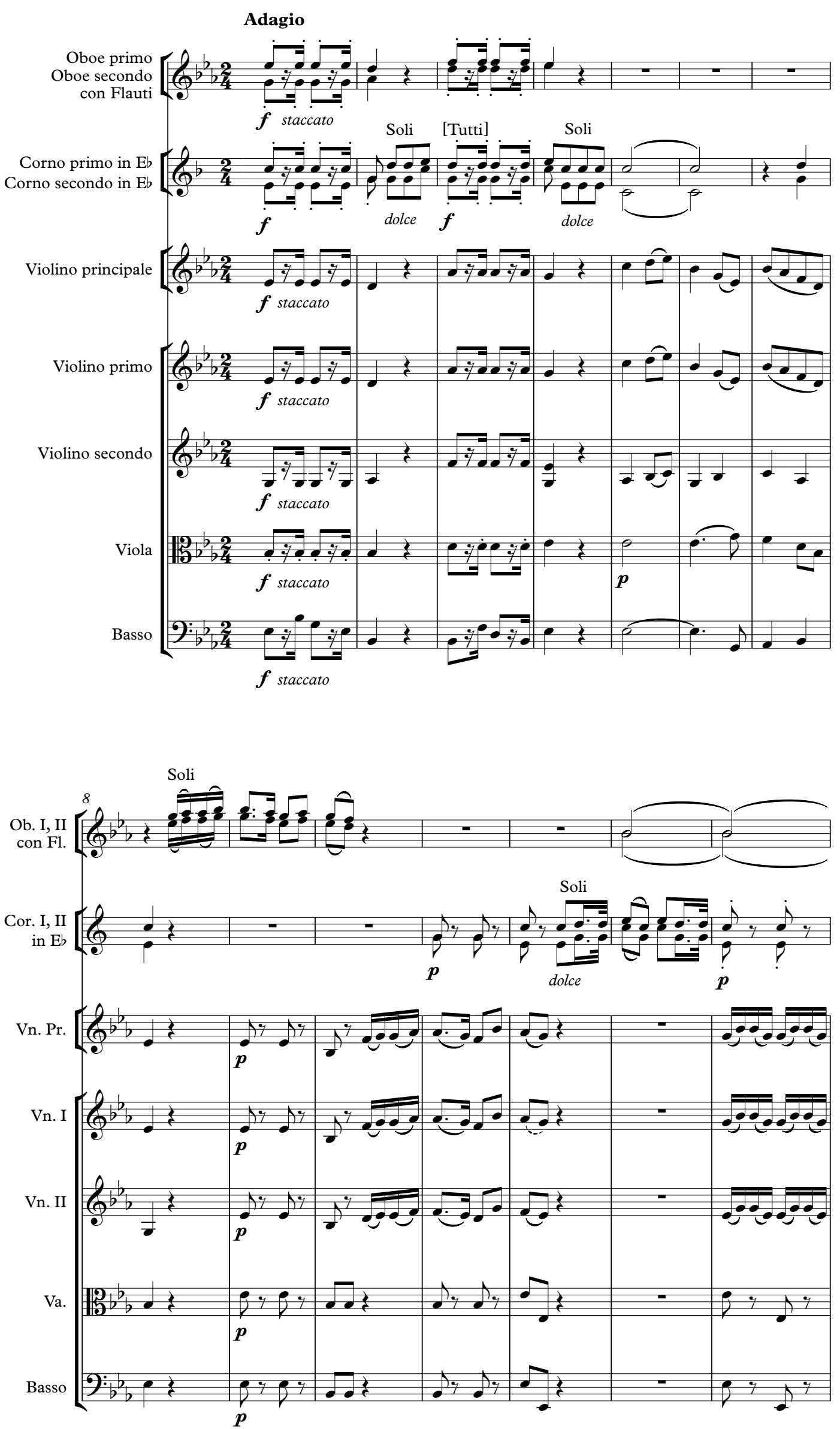

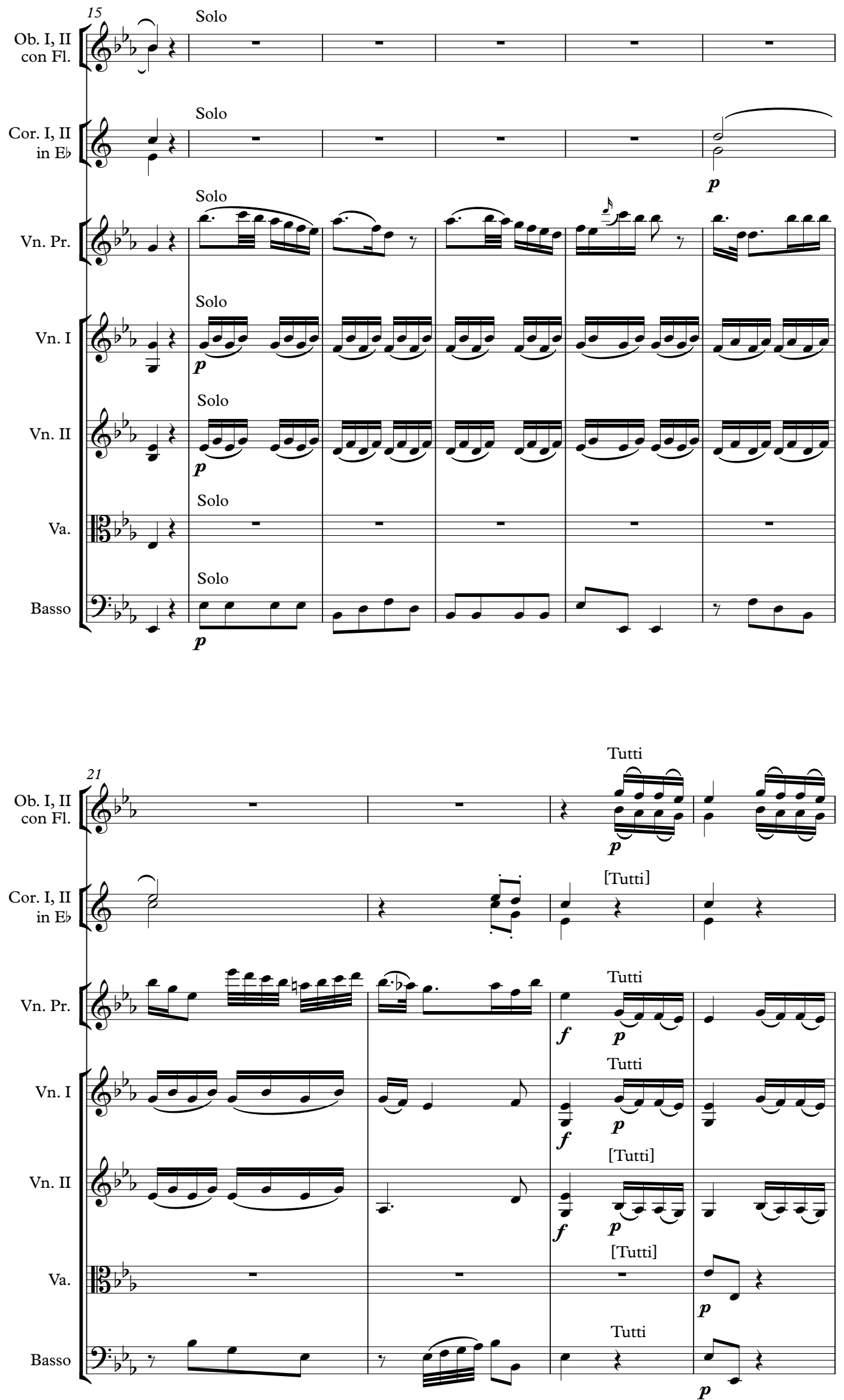

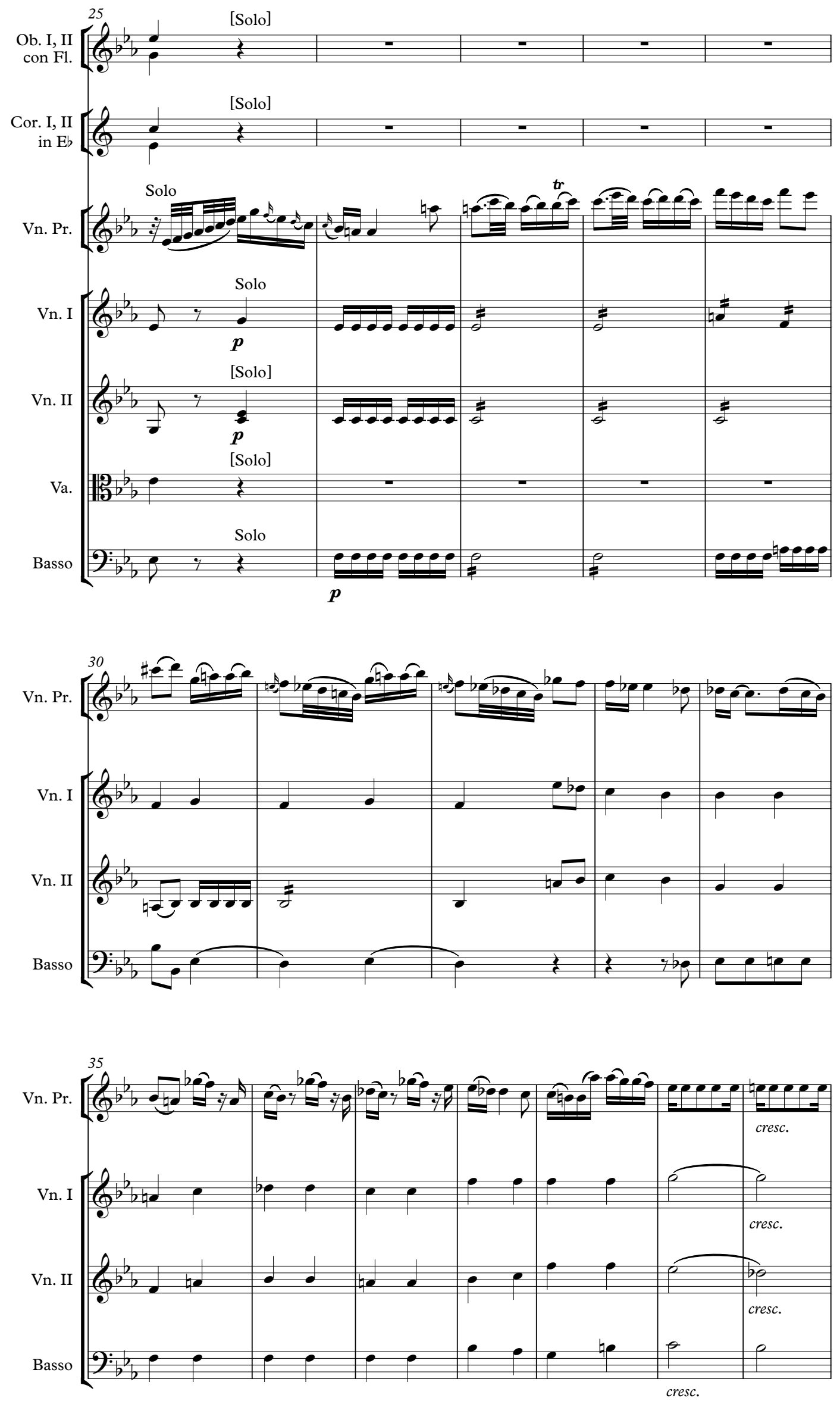

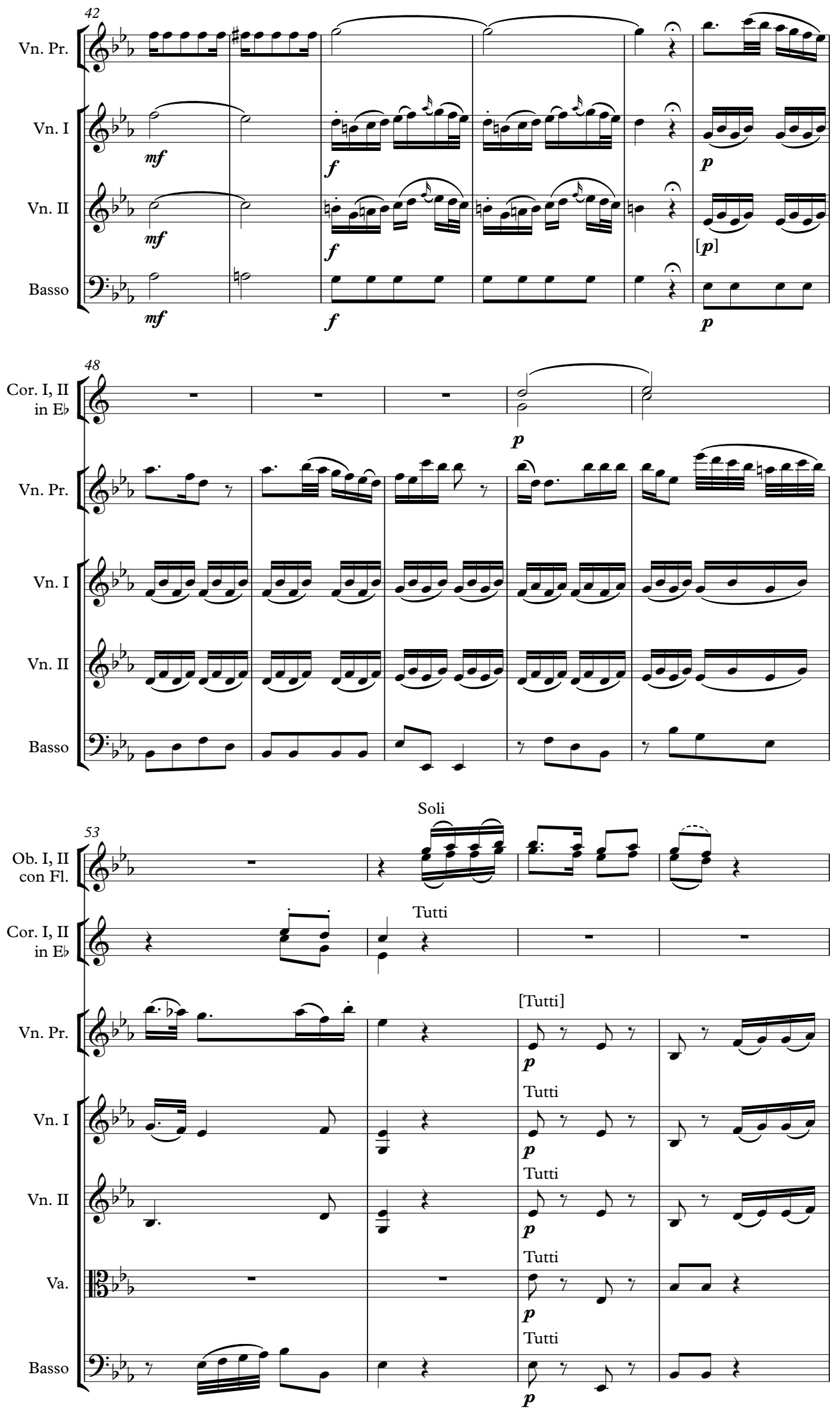


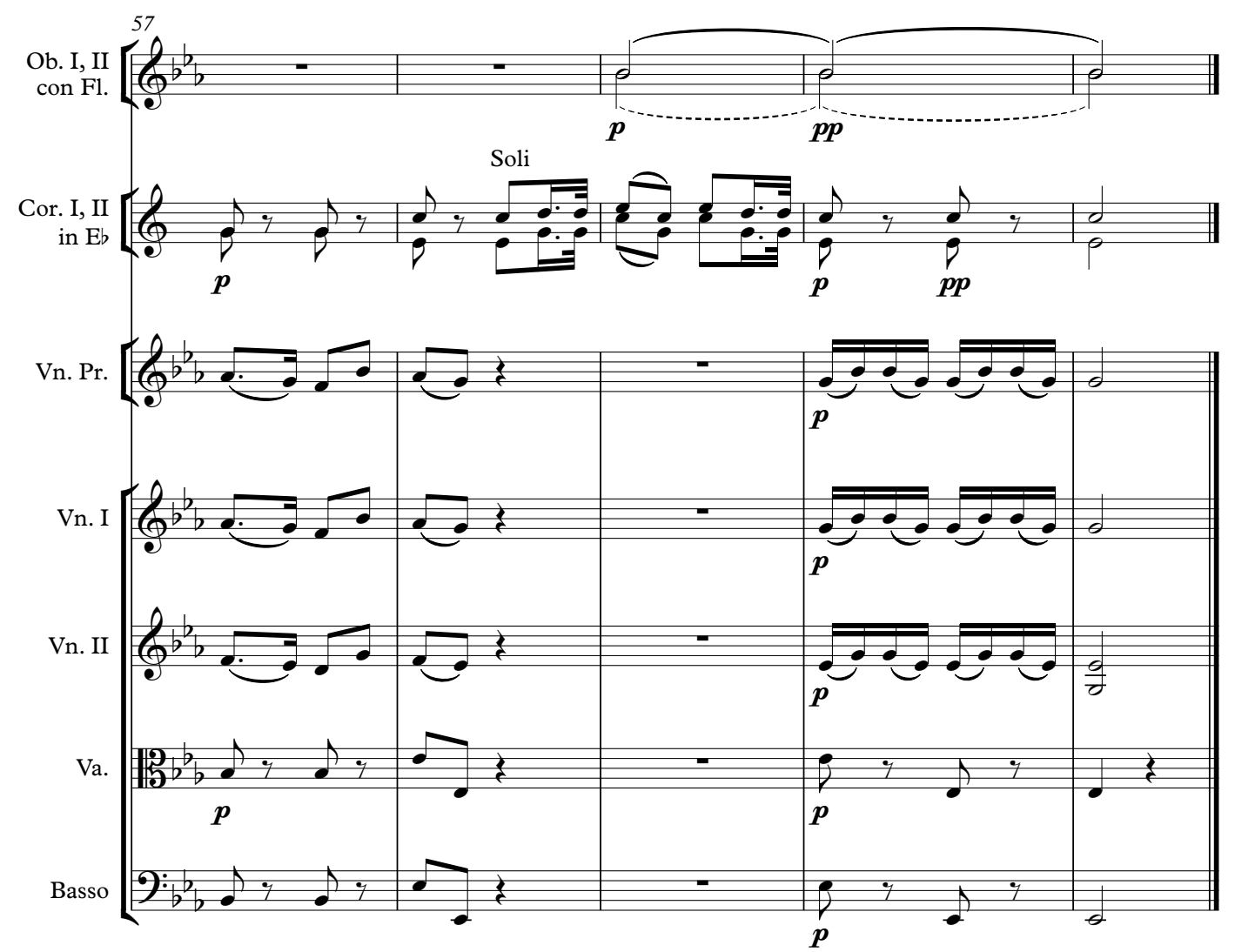



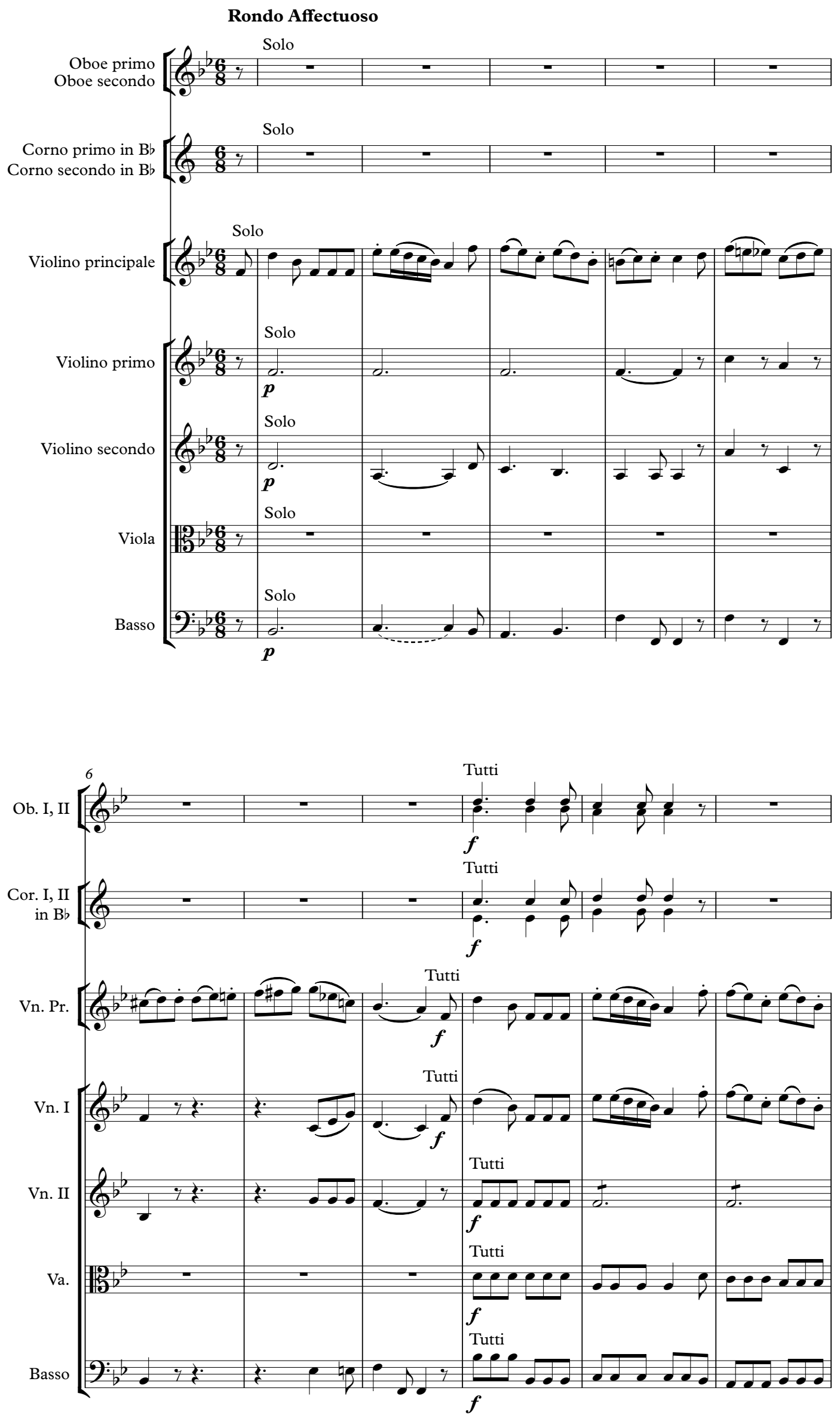

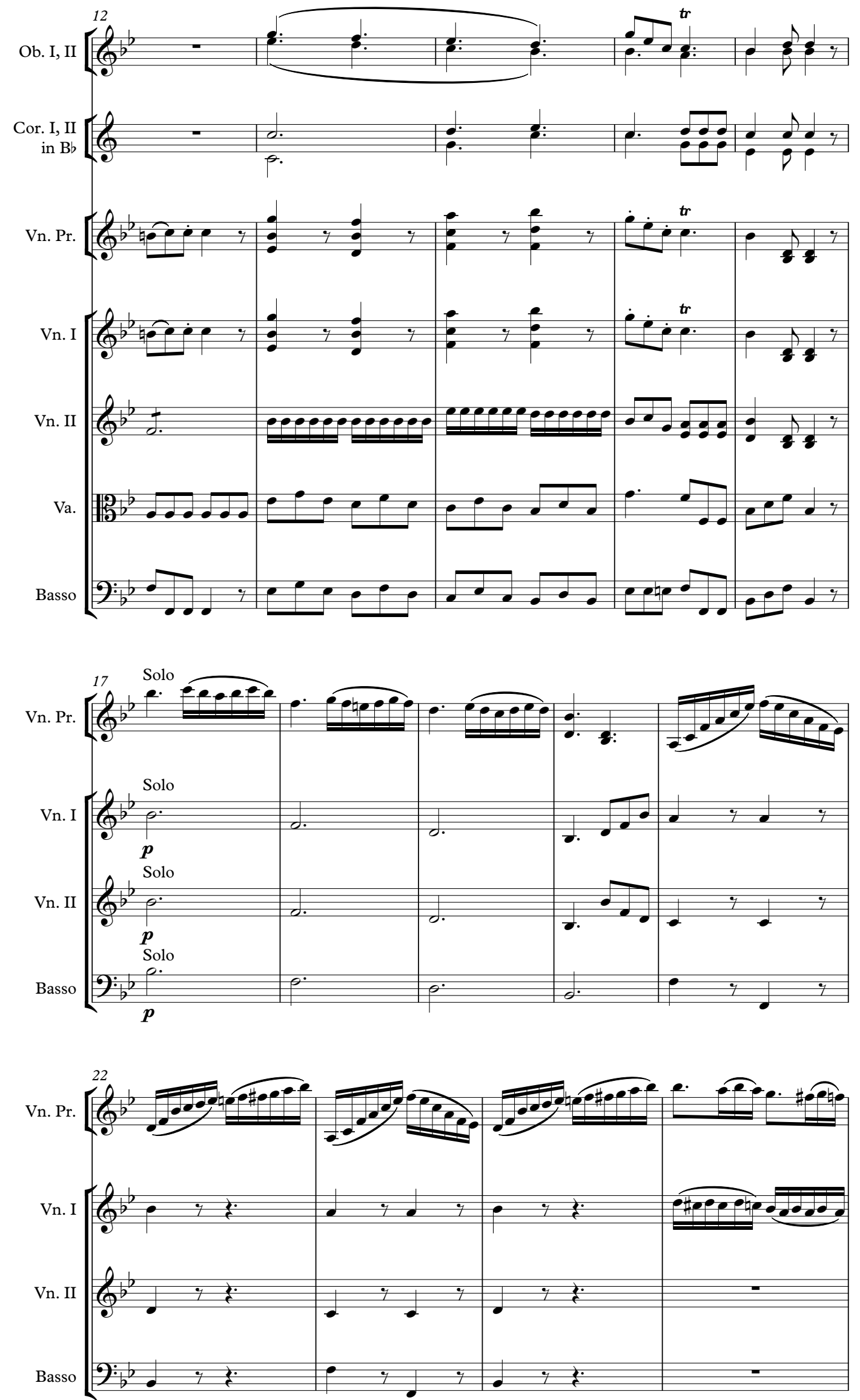

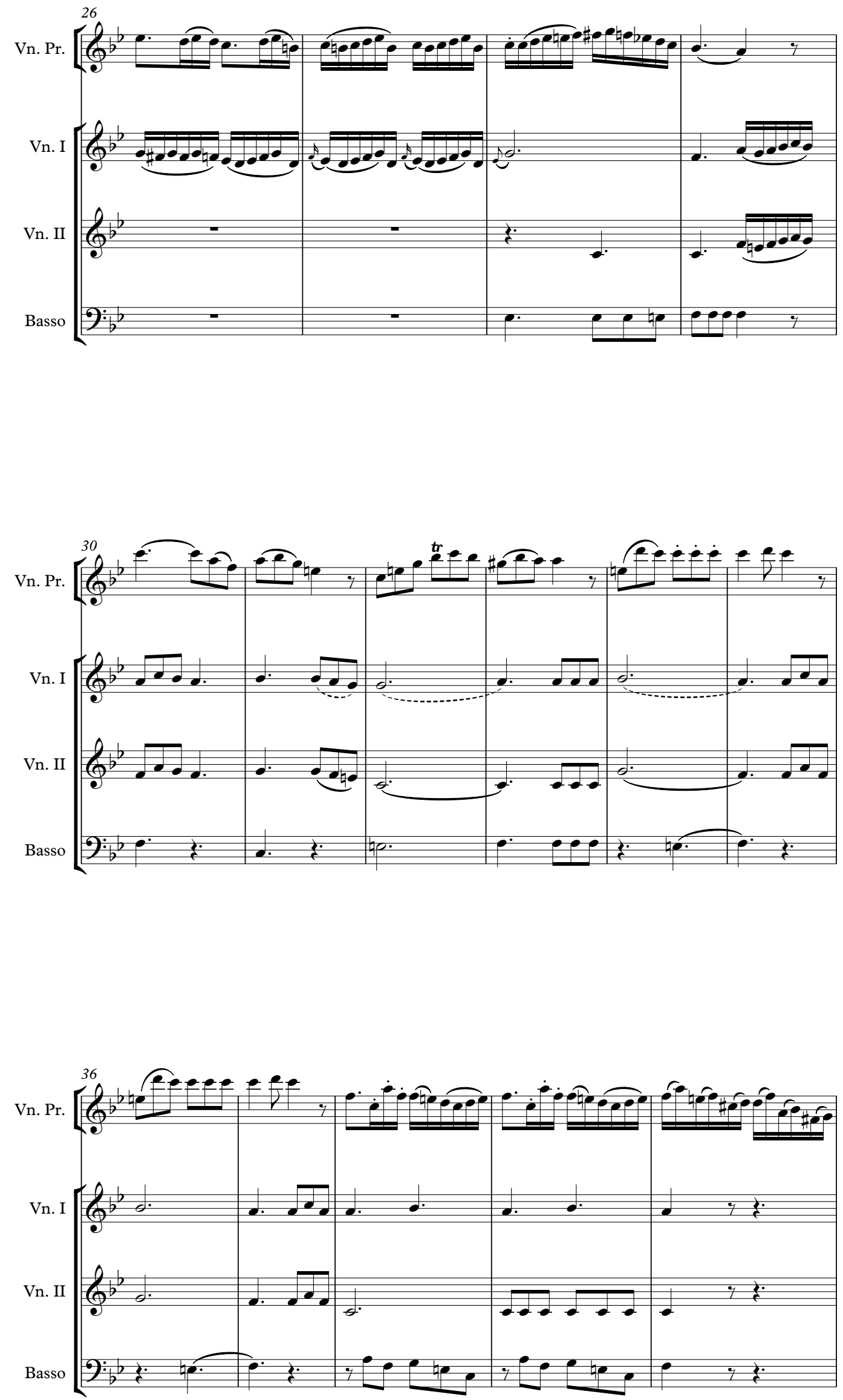
28
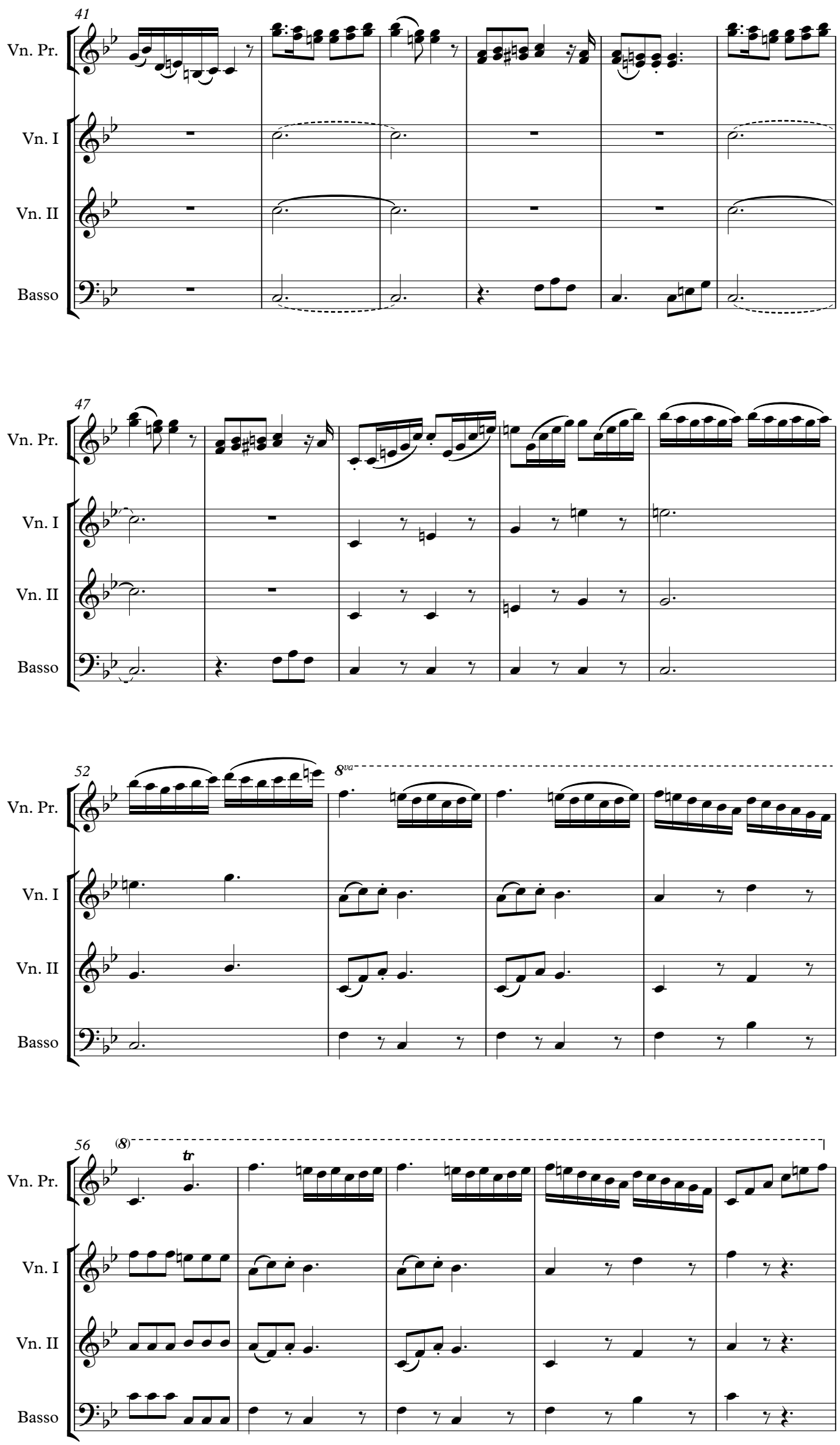

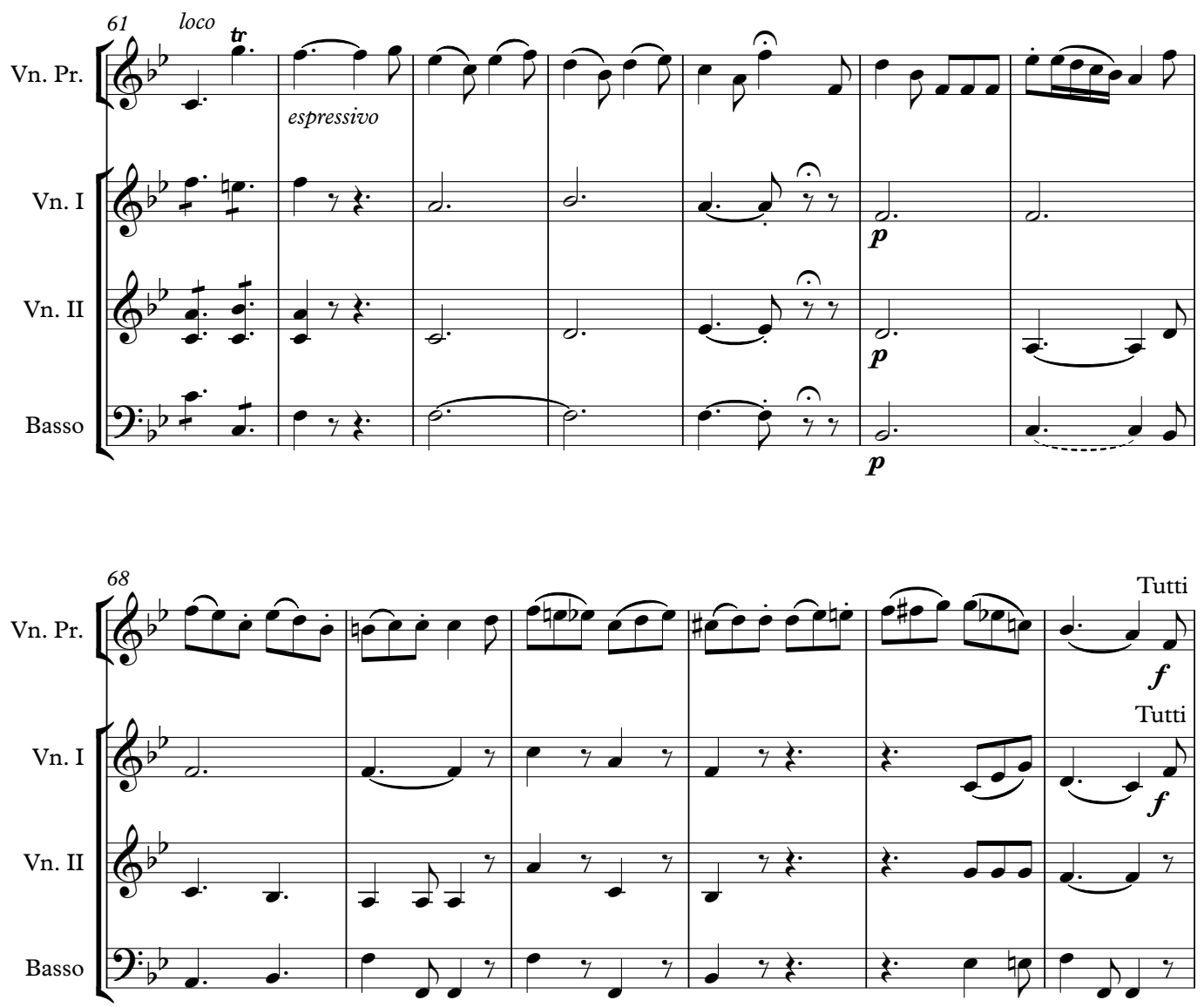

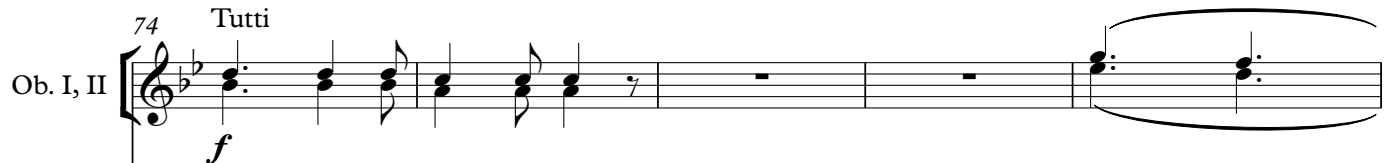
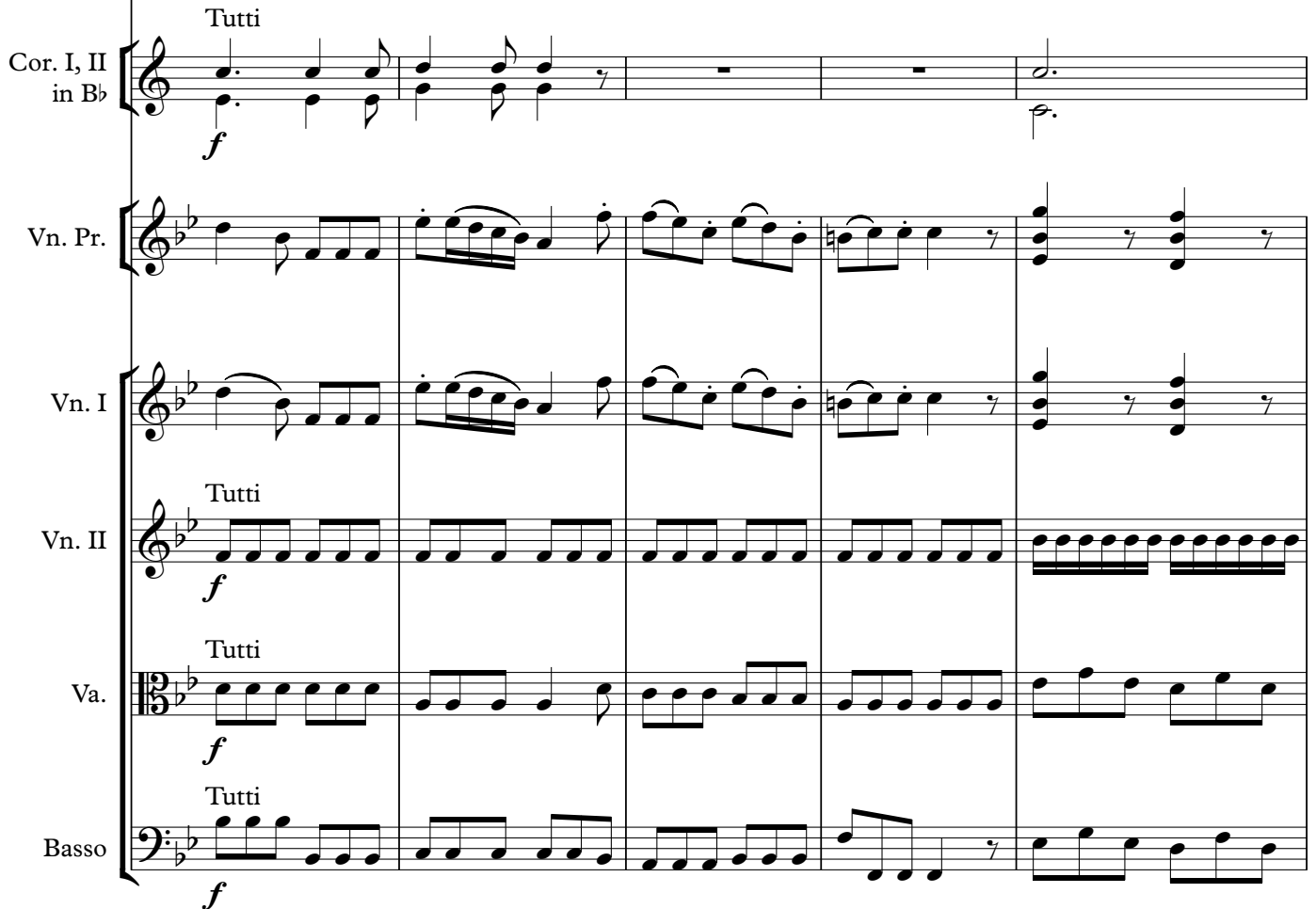

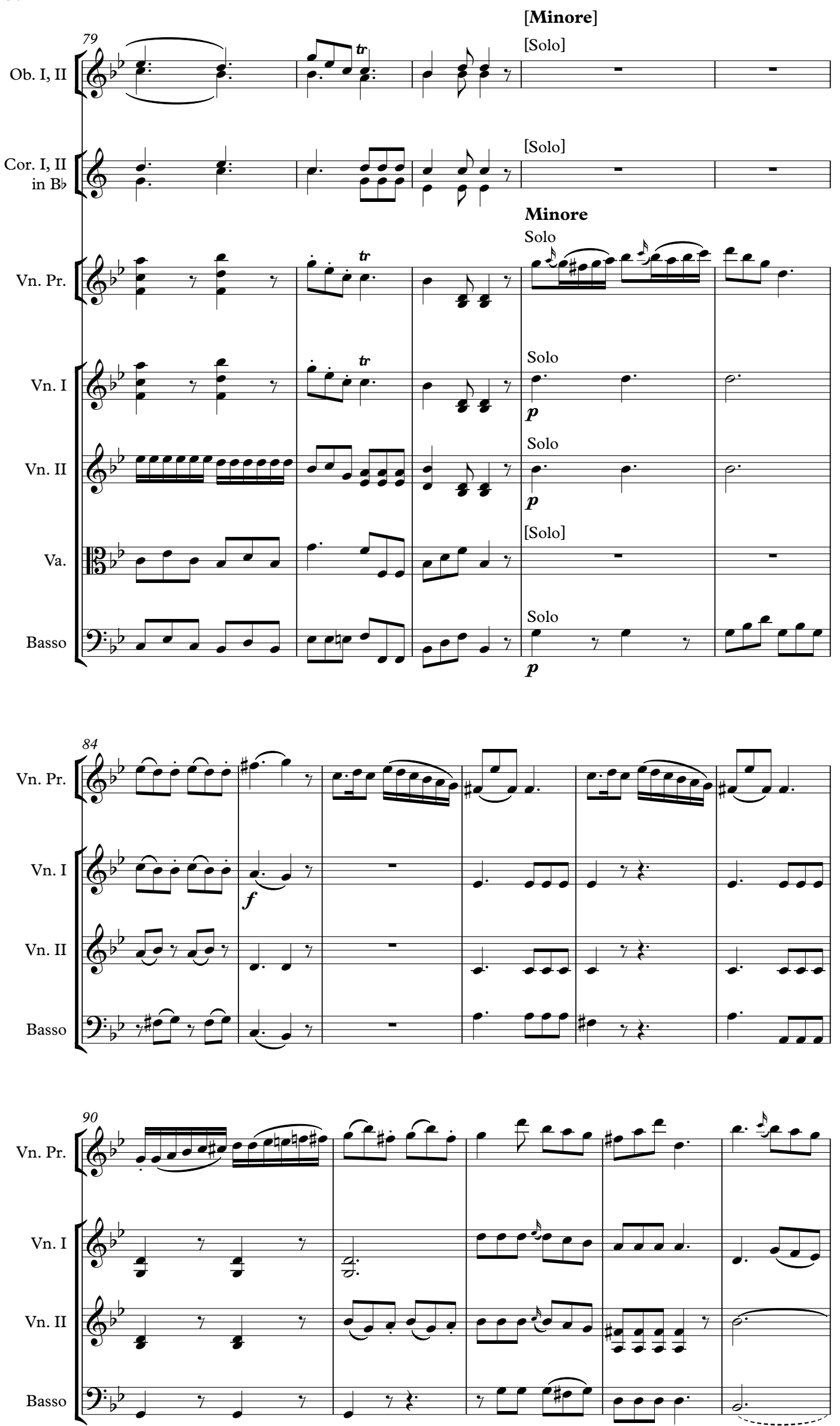

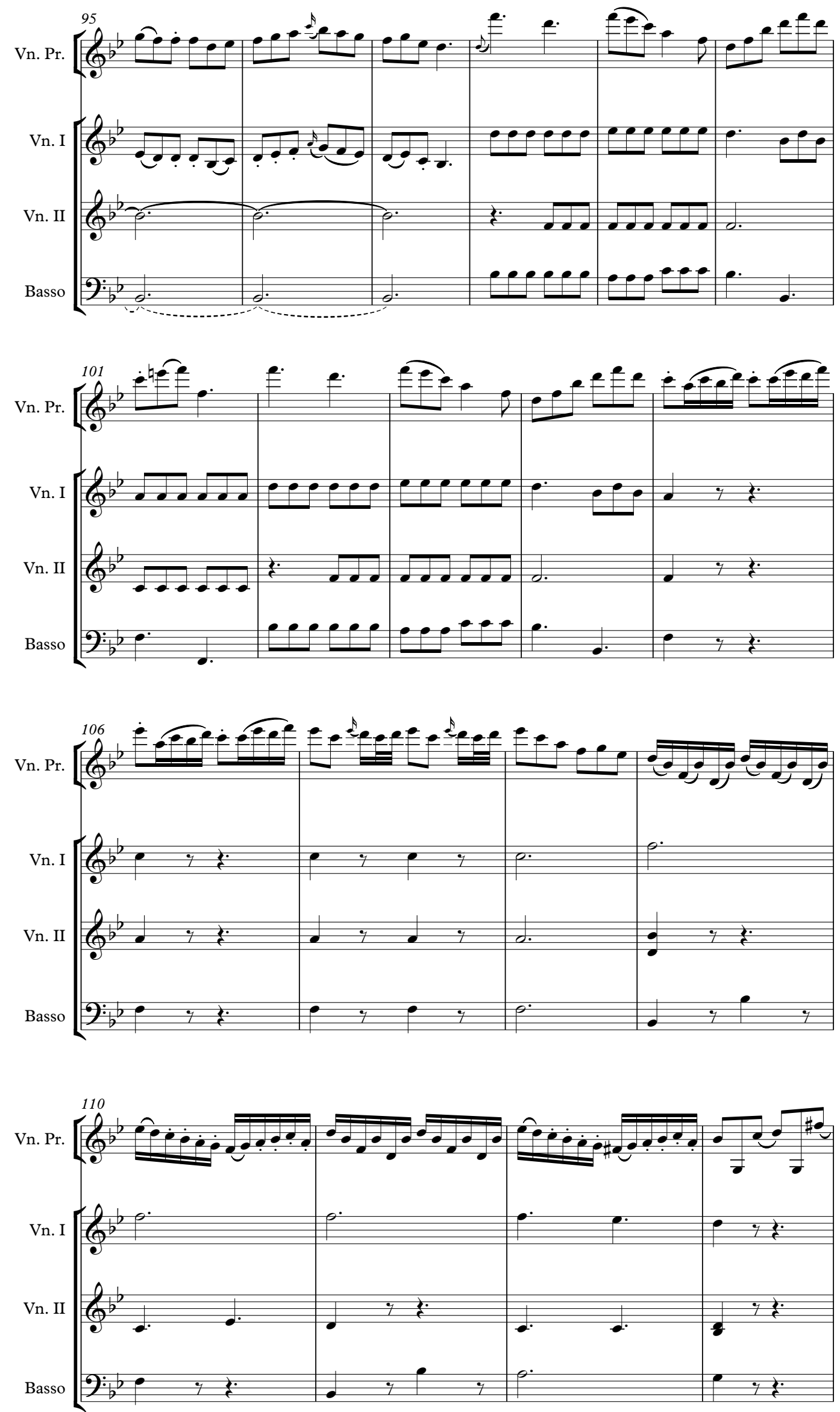

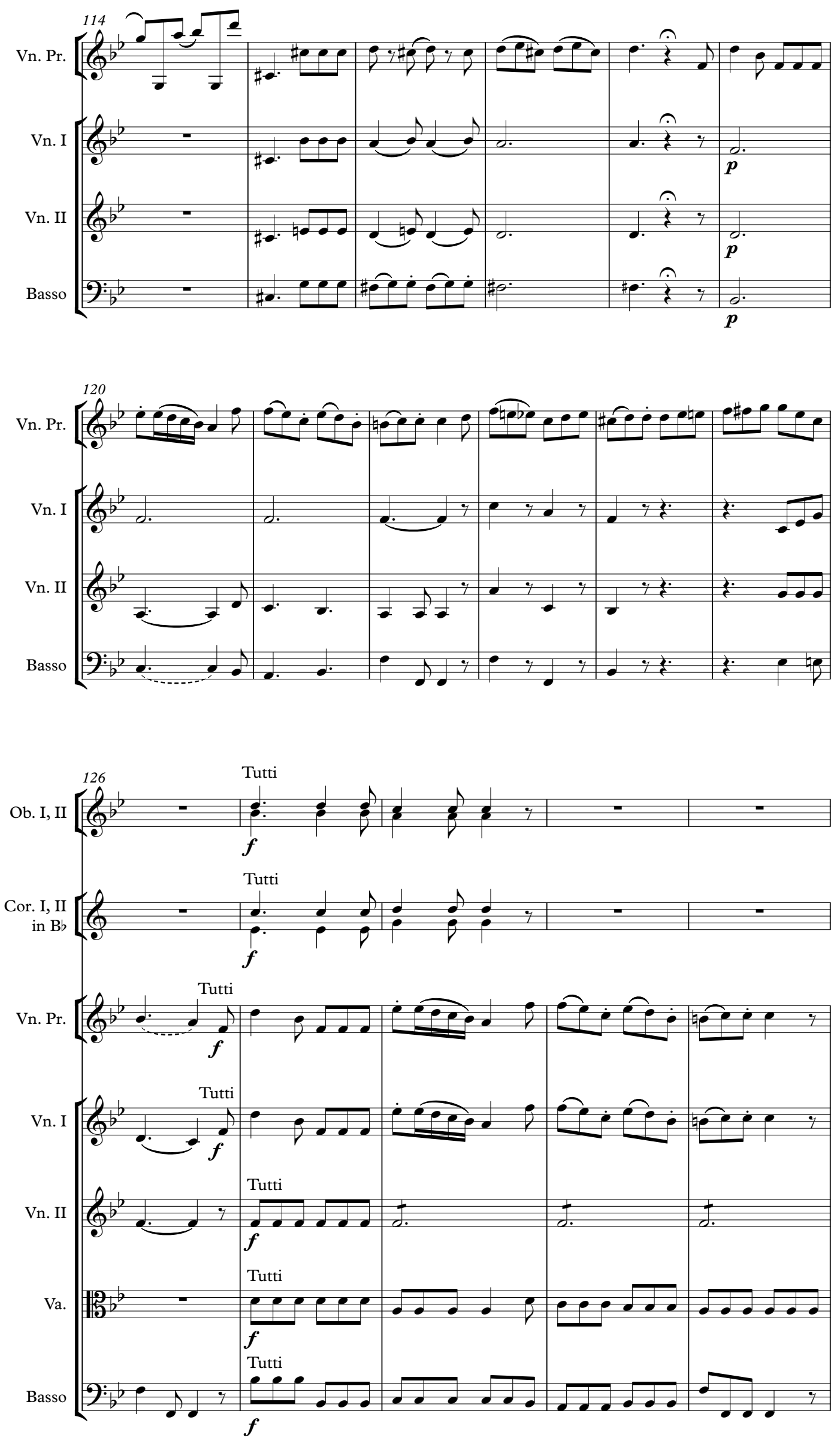

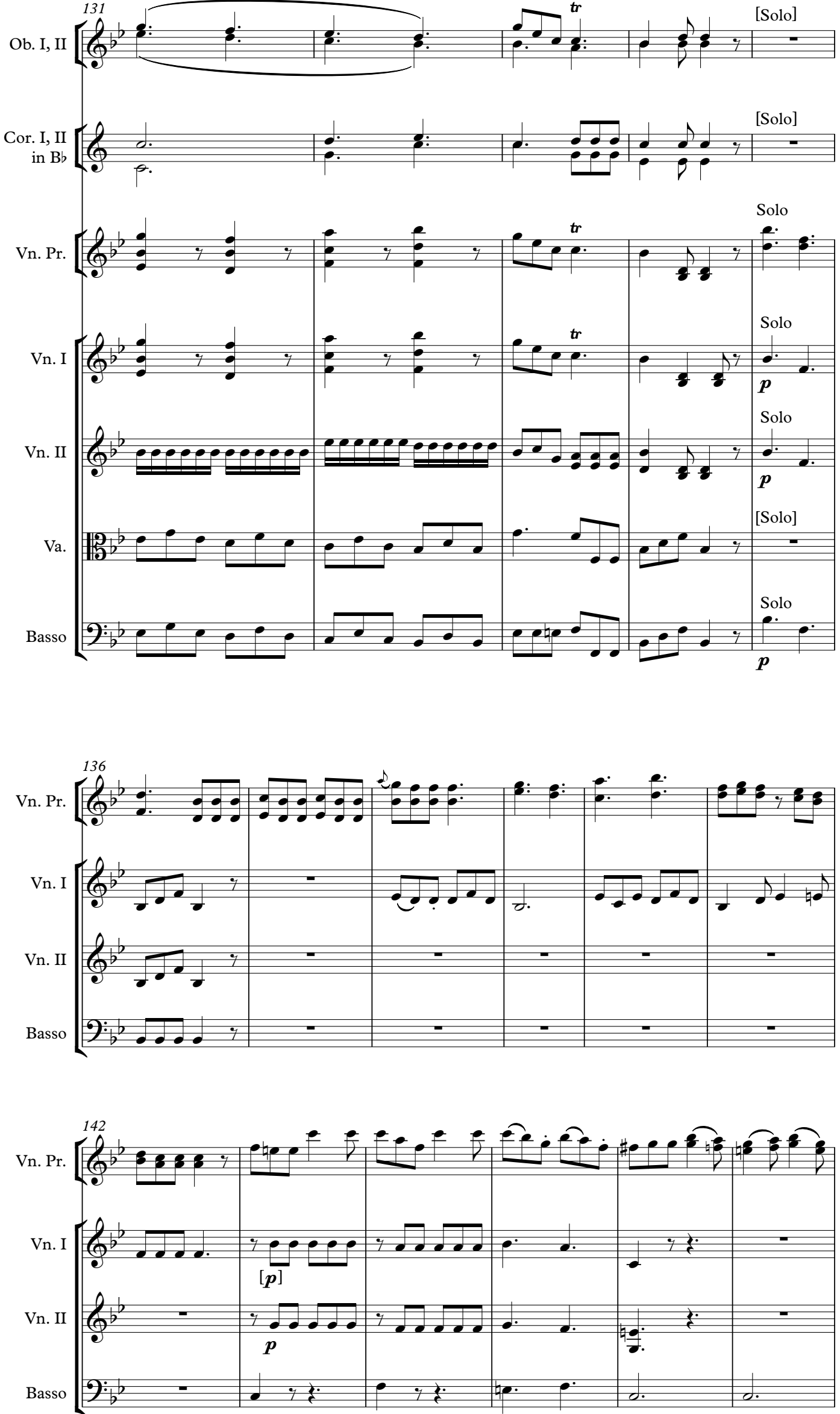

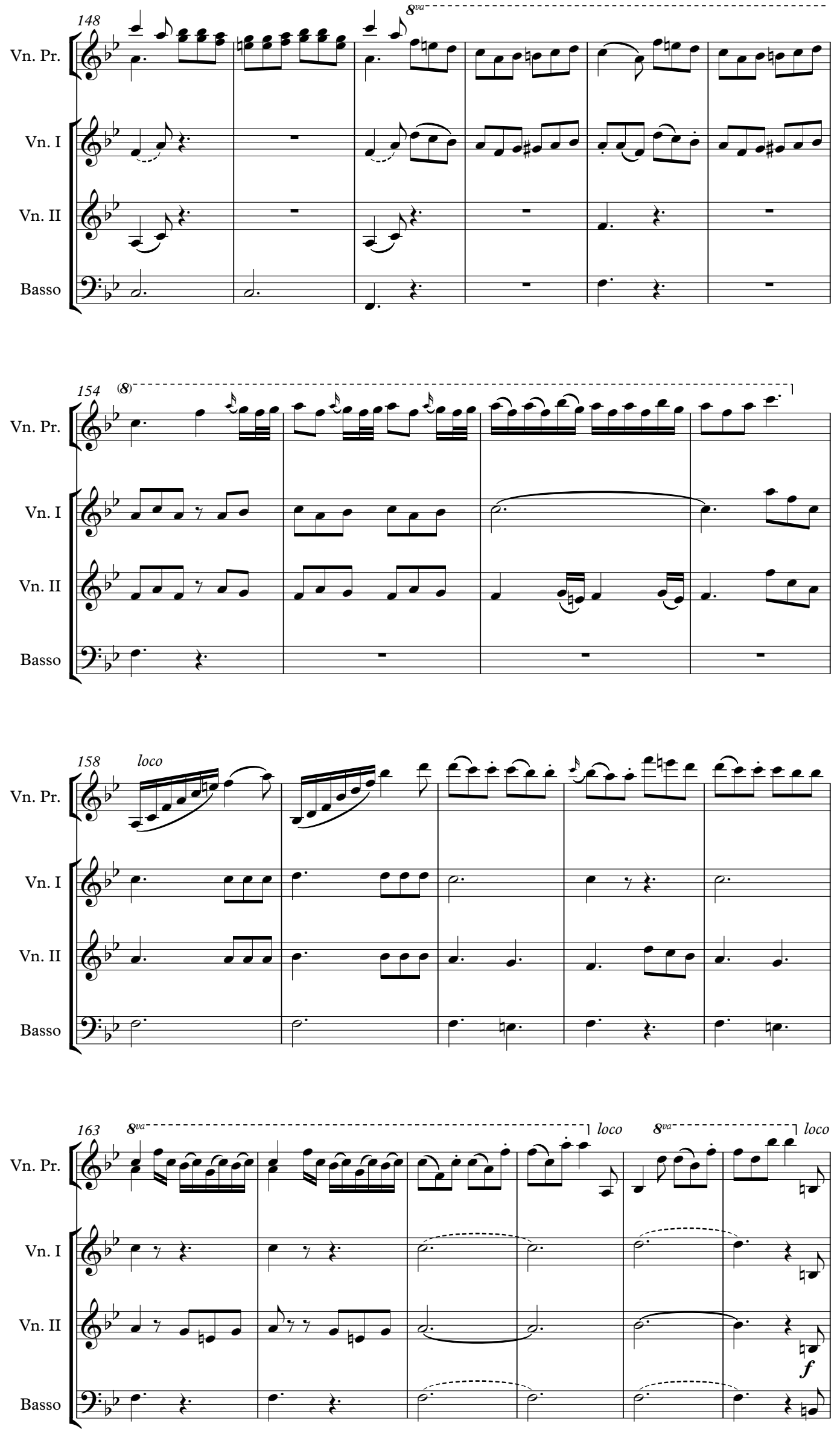

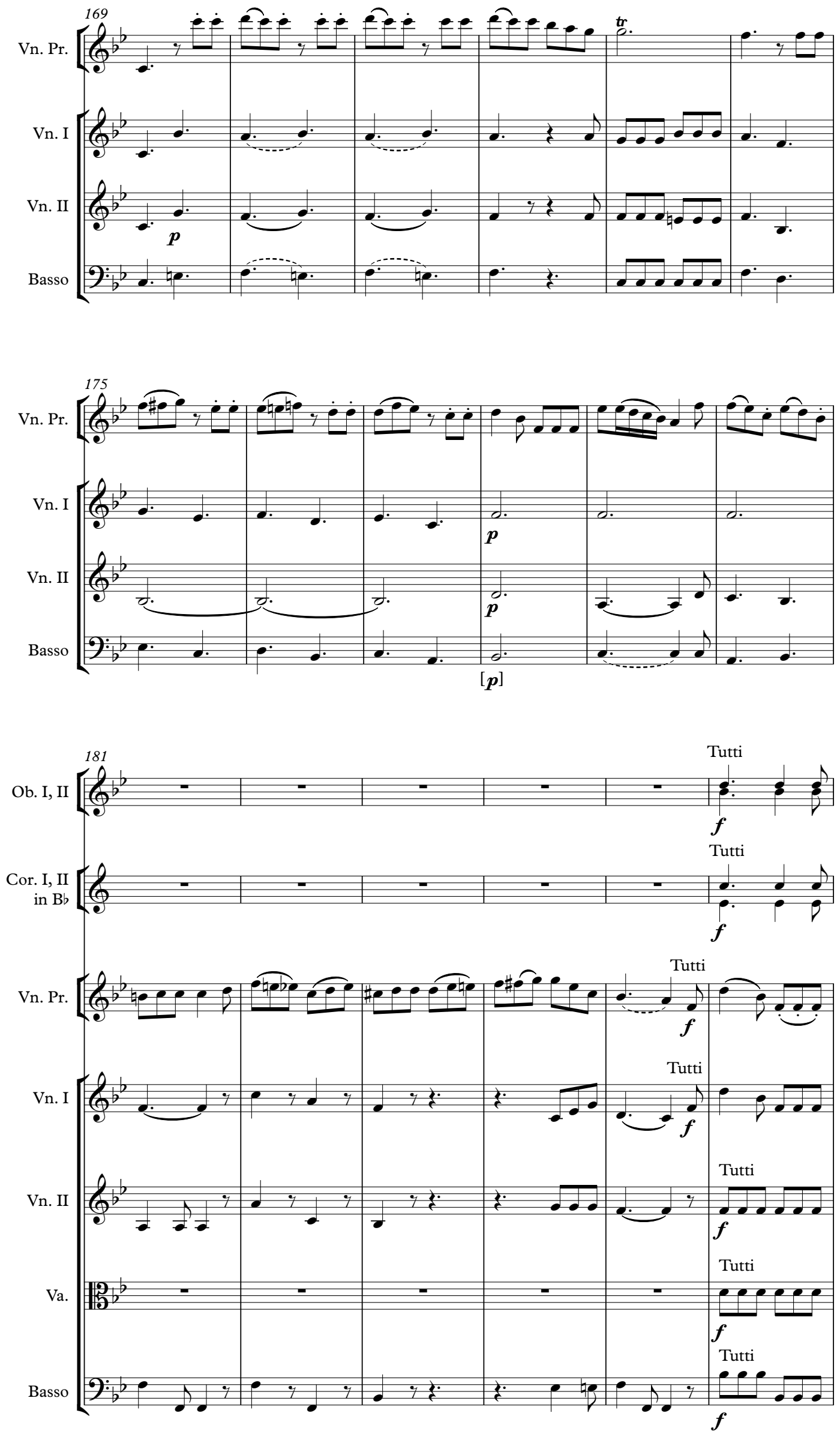

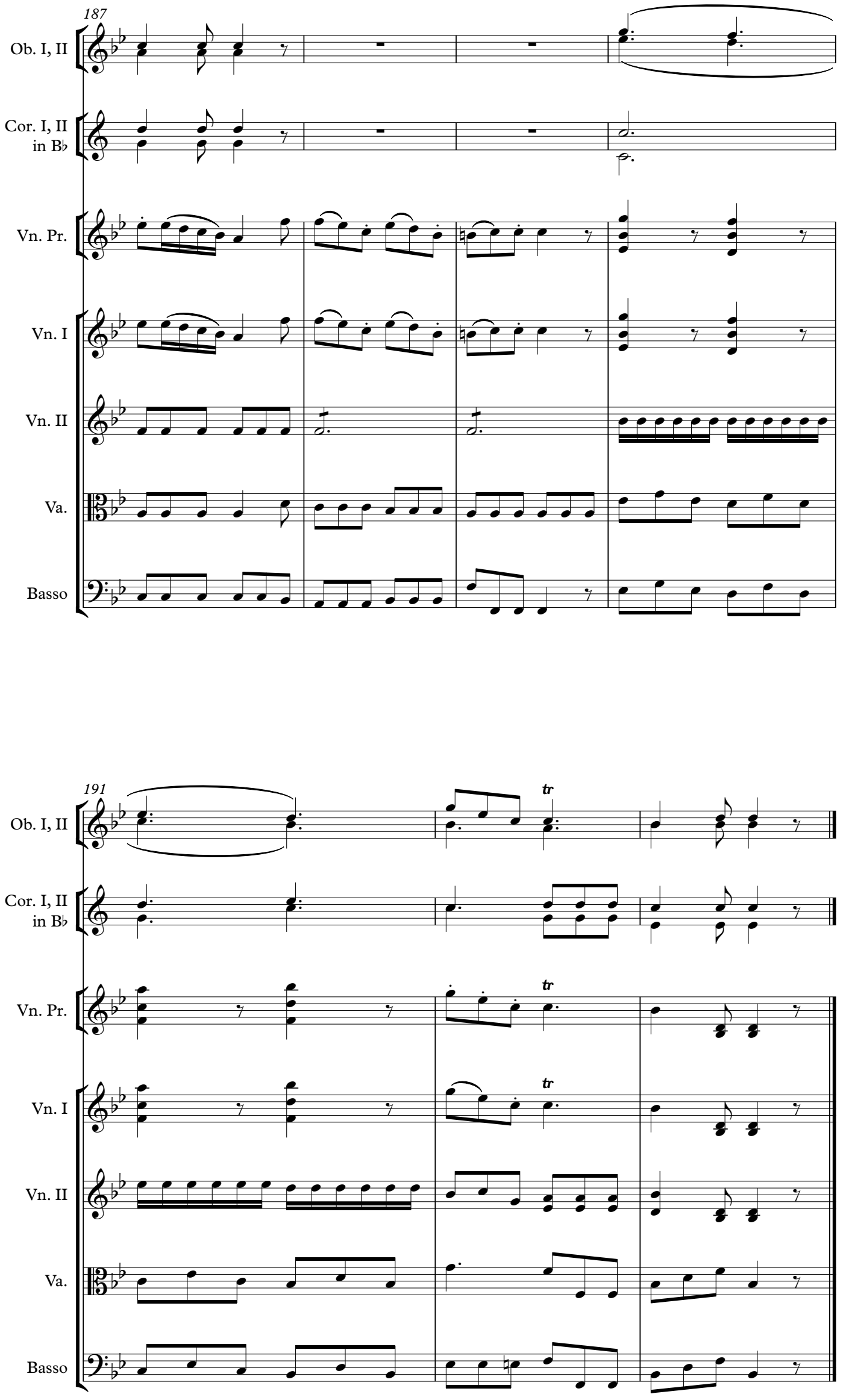